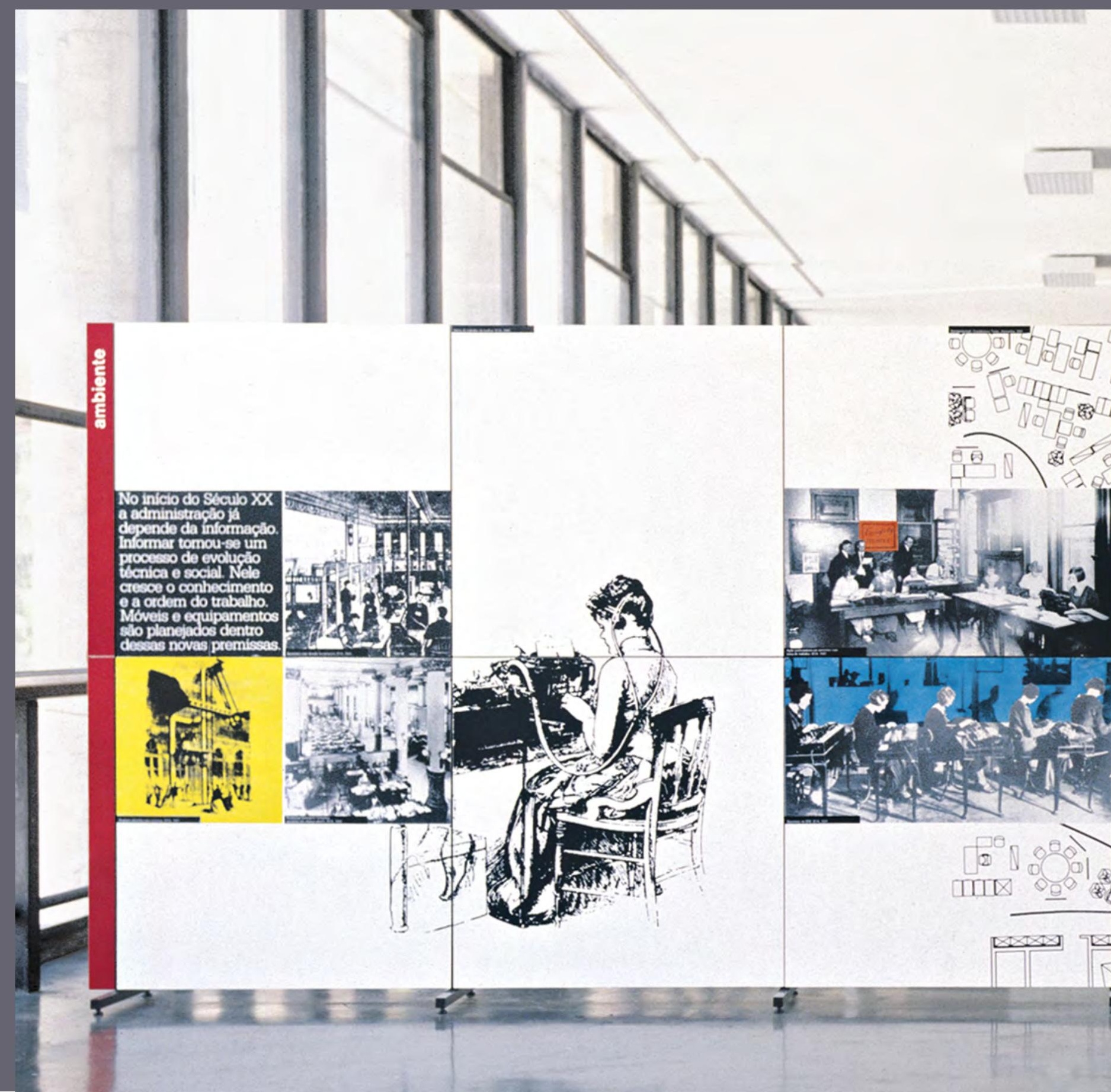




\section{a industrialização e o design de móveis para escritório}

Nas décadas de 1950-60, era comum no Brasil o fenômeno de muitas pequenas oficinas transformarem-se em indústrias. Deixaram de executar produtos sob encomenda, sob medida, que obedeciam a especificações individuais e procuraram uma normalização interna, tentando adaptar-se às normas ou demandas do mercado que, sob uma ótica desenvolvimentista, abria um novo espaço de trabalho para essas empresas. Seus produtos tornaram-se seriados, e o que antes era executado por um técnico qualificado passou a ser feito em diversas etapas por operários e com a ajuda de mão de obra não necessariamente especializada, mas sempre sob a direção e controle de técnicos. Nesse primeiro passo da industrialização, as construções, instalações, máquinas e ferramentas mudaram pouco. Mudou a metodologia de trabalho, o critério de ordenação da produção e o layout de fabricação. O que mudou radicalmente foi a relação com o consumidor. Antes era quase pessoal e direta. Com os novos critérios, os produtos começaram também a ser vendidos em lojas, por representantes comerciais, mediante especificações em catálogos e também, em função de informações publicitárias. Deixou de ser uma relação direta entre produtor e cliente e tornou-se um processo anônimo e relativamente indireto.

O setor de mobiliário foi um dos mais representativos dessas mudanças, principalmente no mobiliário destinado a um uso coletivo, como o mobiliário hospitalar e, principalmente, o mobiliário para escritório. Pode-se dizer que, nessa época, o mobiliário para escritórios era um produto industrial de complexidade relativamente baixa e que, por diversos fatores, cresceu muito a demanda por esse tipo de produto. Em primeiro lugar, o deslocamento de uma grande quantidade de mão de obra para processos indiretos de trabalho, para processos de trabalho administrativos, no qual o mobiliário era elemento básico. Além disso, a construção de Brasília significou a criação de um gigantesco centro administrativo. As fábricas paulistas, que dominavam o mercado do mobiliário, começaram uma intensa produção visando suprir a demanda de três centros principais de mercado: São Paulo, o mais tradicional; Brasília, a nova demanda e o Rio de Janeiro, cidade que tendo suas características de capital federal transferidas, buscava uma nova configuração administrativa, eventualmente centrada na hipótese do mercado financeiro. Nessa ocasião, julgava-se que o setor de mobiliário para escritórios tinha uma perspectiva de futuro seguro porque estatísticas e previsões econômicas Ihes garantiam um crescimento constante.

Nessa época os escritórios ainda eram instalados de uma forma relativamente primitiva, principalmente se for feita uma comparação com as exigências de hoje. Usavam-se escrivaninhas, que podiam ser grandes, médias ou pequenas, poltronas giratórias, de espaldar alto, médio ou baixo, variáveis pouco objetivas, sempre definidas em função de hierarquias relativas ao futuro usuário. Havia ainda os gaveteiros, armários, credenzas para guardar documentos, mesas 
"Foto emblemática que mostra uma conversa entre candangos na época da construção de Brasilia, por volta de 1959, numa tarde de domingo.

Provavelmente não se vê mais essa cena hoje em Brasilia. Mas, cerca de 25\% da população mundial continua adotando essa postura ao sentar, não apenas para lazer e descanso como também para trabalhar".

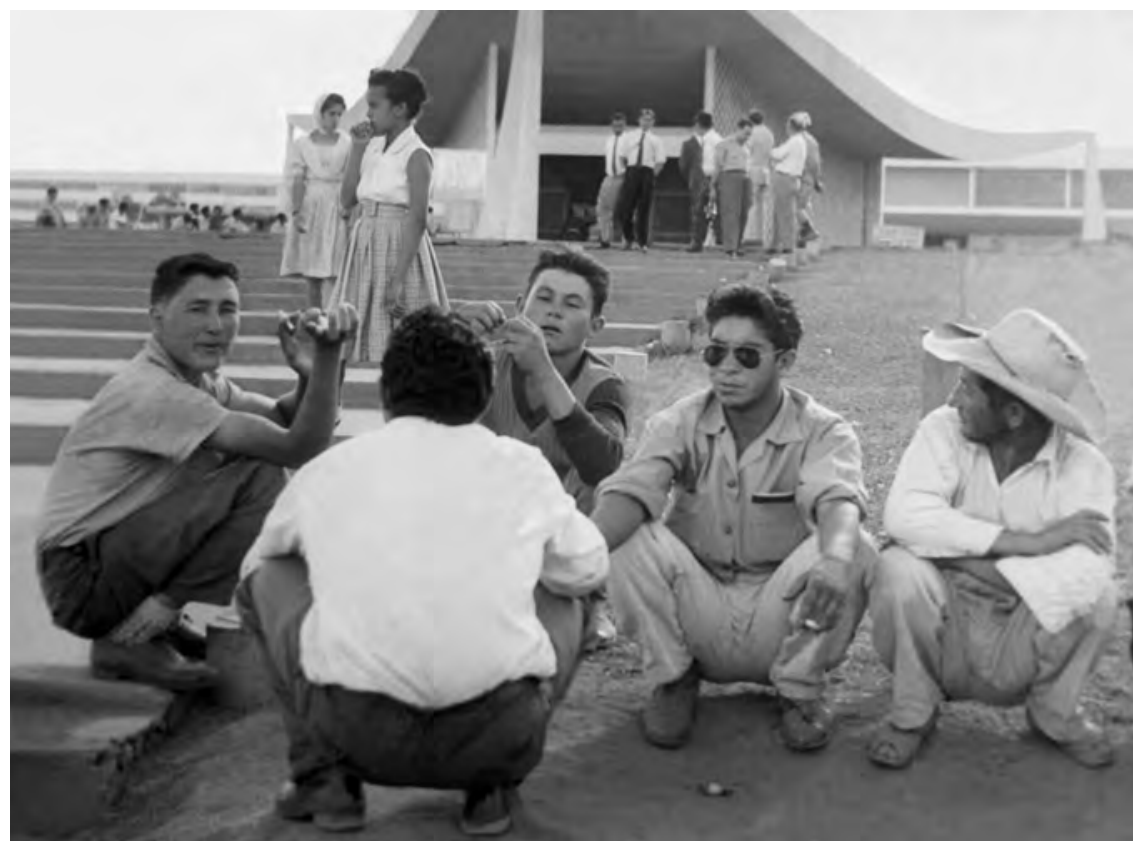

redondas, ovais e compridas para as reuniões e a famosa mesa para máquina de escrever, com sua cadeira giratória, espaço de trabalho no qual, pela primeira vez, levantou-se o problema da ergonomia como algo relevante nos móveis destinados ao setor de serviços. Como diz Bergmiller, "Mas como a datilógrafa era uma mão de obra barata, poucos empresários ficaram convencidos em investir adequadamente em seu posto de trabalho. Hoje essa moça chama-se digitadora, programadora, uma pessoa que opera equipamentos caros e sofisticados. Agora todos aceitam que mesas e cadeiras devam ser ajustadas a seu físico, e o resultado é evidente: ela reclama menos das dores nas costas e de problemas na vista, falta menos ao serviço, e isso resulta em maior produtividade. Ela está um pouco mais feliz em seu trabalho e o empresário, talvez, um pouco mais rico. São os benefícios que a ergonomia traz sob uma ótica capitalista."

Mas, a maior parte do mobiliário de escritório fabricado até então pelas grandes empresas, era pesado, feito em chapas metálicas, de madeira compensada ou maciça e, quase sempre, pintado de verde ou em madeira escura. Foi Florence Knoll que, pela primeira vez, apresentou um conceito diferente: esqueletos de tubos metálicos quadrados e cromados, pranchas de madeira fixadas por cima como tampos das mesas e containers pendurados embaixo. Esse conceito espalhou-se rapidamente pelo mundo todo, inclusive no Brasil. O sistema facilitou muito a fabricação, o estoque, a terceirização, o transporte e a manutenção, além do intercâmbio de componentes. Bergmiller acha que, em sua essência, essa ideia está presente até hoje em diversas variáveis de projetos de mobiliário para escritório. Essas considerações sobre suas ideias relativas ao mobiliário para escritório das décadas de 1960-70 enquadram-se perfeitamente na fase inicial da Escriba, indústria na qual desenvolveu seu mais extenso e complexo trabalho, durante mais de trinta anos. 


\section{a Escriba}

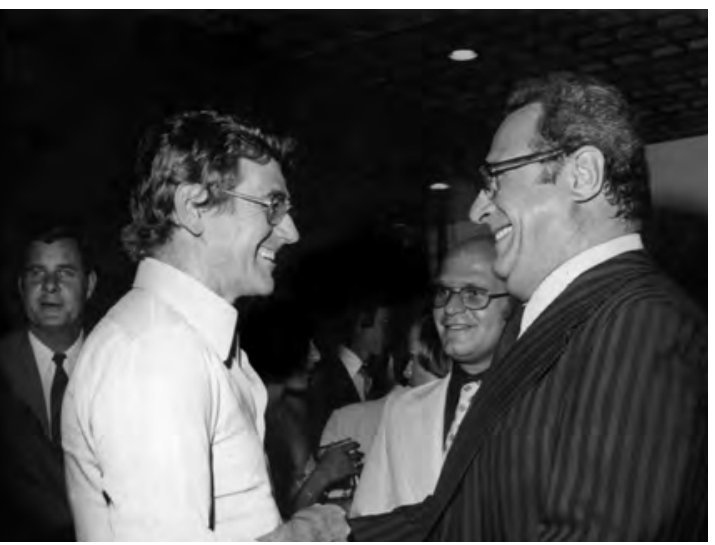

O contrato com a Escriba foi inicialmente previsto para um ano mas, devido aos resultados positivos foi renovado permanentemente. Desenvolver uma programação de longo prazo sempre é uma atividade mais complexa. Num pais sujeito a oscilaçóes econômicas esse trabalho torna-se mais delicado ainda. Além disso, os projetos para mobiliário de escritório sempre devem atender às demandas técnicas e organizacionais mais atualizadas e desenvolvidas. A informática foi, nos últimos trinta anos, a propulsora dessas mudanças. Os fabricantes esclarecidos souberam acompanhar essas novas exigências valorizando-as mais que simples alteraçóes estéticas e formais. Demandas técnicas e funcionais são sempre mais importantes que as tendências ou ondas estilisticas e nessa concepção o designer pode exercer um papel importante.

A Escriba nesses trinta anos integrou o design à sua politica geral e passou por algumas etapas nesse processo:

- transformou-se de uma oficina em uma indústria de seu tempo, preocupada com produtos seriados e codificados, apresentando possibilidades de desmontabilidade, parcialmente terceirizados em sua fabricação;
O jovem economista José Serber, então com trinta anos, que havia atuado com sucesso como ator no teatro e na televisão, procurou alguma coisa mais consistente e segura para fazer. Comprou uma marcenaria, mas, desde o início, não pensou em dar continuidade aos métodos de trabalho artesanais. Imaginou essa oficina como o núcleo de uma futura fábrica. Alguns arquitetos amigos desenharam para ele um conjunto de produtos. Havia na marcenaria uma pessoa muito singular: "um grande marceneiro espanhol", como diz Bergmiller. O Sr. Vicente era, de fato, um marceneiro tão competente quanto mal-humorado. Mas, por trás disso havia um bom caráter, ainda que desconfiado dos novos métodos que não o colocavam mais como elemento central nas questões técnicas e de fabricação. Lembro-me muito bem de meu primeiro estágio na Escriba. Bergmiller, sem me dar mais informações, colocoume para desenvolver os protótipos de algumas juntas que queria introduzir nos móveis da Escriba. Vicente desconfiava das novas soluções; olhava os desenhos e dizia, invariavelmente, com sotaque espanhol: - "No va dar". Fez parte do meu aprendizado. Foi Vicente quem viabilizou os primeiros produtos da Escriba, antes de Bergmiller assumir o seu design. Nessa época, o cunhado de José Serber, Mário Grosbaum, engenheiro, entrou para a sociedade e assumiu a responsabilidade pela produção.

O nome Escriba surgiu numa conversa informal entre amigos, sugerido por Geraldo de Barros. Não houve nenhuma pesquisa de mercado e nenhum custo para isso, mas funcionou, deu certo. Como diz Bergmiller "eram outras épocas", e continua sua narrativa: "Conheci José Serber ainda em São Paulo. Era muito amigo de Leo Seincman, amigo meu também, industrial, dono da Probjeto, uma fábrica de móveis de boa qualidade. Leo foi um grande incentivador de José, que na época estava muito interessado e ligado às atividades da ABDI, Associação Brasileira de Desenho Industrial. José tinha sido ator e sempre aparentava bom humor e grande facilidade de comunicação dentro e fora de sua empresa. Mudei para o Rio em 1967, achando que precisava ficar mais próximo da ESDI que, na época, apresentava seus primeiros problemas. Mas, logo depois, fui procurado pelo José no Rio propondo-me cuidar da implantação de um programa de design na Escriba". E prossegue, literalmente: "Curioso é, de vista-retrospecto, que em São Paulo fui procurado pelo então secretário de Educação do Estado da Guanabara, Carlos Flexa Ribeiro, para participar da estruturação da ESDI e, logo depois, no Rio de Janeiro, o José Serber da Escriba me visitou e solicitou meus serviços profissionais em São Paulo. Acordo acertado, continuei na ponte aérea no sentido inverso. Elaboramos um programa de trabalho, inicialmente para um ano, com objetivos claros de introduzir na Escriba uma ideologia de design".

Diz Bergmiller, a respeito dessa proposição, que uma das principais questões é que o designer saiba propor e realizar projetos dentro de prazos definidos e que seja capaz de cumprir com responsabilidade os compromissos assumidos, porque a pontualidade também tem seu peso na qualidade do trabalho. 
- concentrou-se no conceito de programas completos de produtos e na integração dos diversos programas entre si; - buscou um posicionamento muito claro no mercado conferindo características muito definidas a seus produtos: sobriedade, honestidade, simplicidade, racionalidade e funcionalidade; - procurou também uma identidade entre seus produtos, sua apresentação visual, sua identidade empresarial $e$ até mesmo com sua linguagem persuasiva, na fábrica, nas lojas, nos veículos, catálogos, publicidades, feiras, etc.

Algum tempo depois de iniciado seu processo de transformação, a empresa passou a participar de feiras nacionais e internacionais e estabelecer metas de exportação e intercâmbio com representantes comerciais e fabricantes no exterior, como a Wilkhahn da Alemanha. Passou também a preocupar-se com a sua inserção social e cultural, principalmente através da organização de exposiçôes informativas de médio e grande porte, visando apresentar ao público em geral a qualidade e os principios de um trabalho fundamentado no design.

A Escriba criou um departamento de design que se transformou em uma importante diretriz de sua politica empresarial. Em todas as questóes internas o design serviu como referência buscando desenvolver e fabricar produtos de qualidade por preços compativeis. A Escriba acreditou na hipótese de que seus produtos e sua forma de divulgá-los poderiam influenciar e esclarecer seu próprio consumidor.

Bergmiller - um vínculo de 30 anos com a Escriba Indústria e Comércio de Móveis Ltda. Taboão da Serra, São Paulo. 1967-1997.
"Talvez aqui o designer se diferencie do artista, de um amador e também do cientista. Um artista verdadeiro jamais cria dentro de tempos préestabelecidos, um cientista não pode, normalmente, fazer novas descobertas com prazos impostos. Já o amador, sem método e sem controle analítico, talvez chegue a alguma solução, por sorte ou talento, mas isso pode representar um risco. Espera-se do designer a capacidade de avaliar a complexidade do problema, definindo as etapas e o tempo mínimo para o seu desenvolvimento. Um procedimento metodológico necessita seu timing, e sem ele, numa solução final podem faltar os argumentos convincentes, as justificativas por ter optado por uma ou outra solução. Num trabalho apenas empírico, podem faltar as considerações adequadas e os dados confiáveis e seguros sobre a viabilidade de fabricação, as formas de comercialização mas, acima de tudo, podem estar ausentes os requisitos básicos de funcionalidade do produto em questão. Esse 'espírito' analítico deve estar sempre presente, mesmo em produtos de pequeno porte. Às vezes, alterações mínimas em um produto podem conduzir a consequências em cadeia, positivas ou negativas, porque a maioria dos produtos industriais pertencem ou a linhas, sistemas ou programas de produtos. Quanto mais familiarizado com o tipo de projeto, com a tecnologia disponível, com a organização empresarial e, logicamente, com o desenvolvimento da própria experiência profissional, mais compacto se tornará o tempo necessário para um designer dedicar à análise e ao desenvolvimento de seus projetos".

No caso da Escriba, Bergmiller considerava essencial a definição de algumas premissas: consideração do nível de complexidade técnica dos produtos propostos, investimento necessário em ferramental e equipamento para a produção, estabelecer uma estimativa da quantidade de produtos a serem fabricados, trabalhar com dados confiáveis sobre fornecedores e de serviços terceirizados, desenvolver testes internos e em laboratórios externos especializados para os protótipos; cuidar dos preparativos para a comercialização: catálogos, publicidade, showrooms, lista de preços.

"Já na primeira presença na fábrica da Escriba constatei uma falha construtiva em um produto pronto para a entrega. Apontando a deficiência, mandei ali mesmo fazer o acerto devido, evitando assim uma posterior reclamação ou devolução. Essa rapidez e flexibilidade de mudar, de introduzir algo novo, uma empresa pode perder na medida em que cresça, por que as séries de produto ficam cada vez maiores. Isso só aumenta a responsabilidade do designer: erros de projeto multiplicam-se milhares de vezes".

"A Escriba em sua fase inicial não era mais que um conjunto de oficinas: uma marcenaria precária e nos terrenos vizinhos funcionavam a serralheria e a tapeçaria. Ainda assim, dessa mistura, saíam produtos seriados". Bergmiller recorda-se que, no final da linha de montagem, havia um operário retocando os móveis e eliminando os problemas ocorridos durante a fabricação. Uma vez, ele disse: - "No dia em que esse tipo de trabalho for extinto, a empresa poderá ser considerada uma verdadeira fábrica, uma fábrica da qual sairão produtos de qualidade". Em outras ocasiões, ele fez menção ao designer como 
"o vigilante permanente em todas as questões de qualidade". Ao dizer isso se referia à necessidade de estar o designer permanentemente atento a todas as etapas de projeto e de produção, até mesmo de inserção do produto no mercado, procurando evitar ao máximo a possibilidade de que algo ocorresse à sua revelia. Isso não significa que o designer seja instituído como outro tipo de censor, a exemplo do marketing, mas que, à semelhança dessa atividade, seja ela também compreendida como uma função básica e necessária a todos os estágios de projeto, produção e consumo dos produtos industriais.

Desde o início do trabalho na Escriba, o apoio de José Serber e Mário Grosbaum foi integral. Os problemas surgiram na parte técnica em que se tornaram mais visíveis as resistências às inovações. Bergmiller chamava o Sr. Vicente de "grande marceneiro espanhol", sem qualquer sentido pejorativo. Na verdade, tinha e tem um grande respeito por esses profissionais, devendo-se lembrar de que, antes de cursar a HfG-Ulm, ele mesmo fez estudos específicos de marcenaria e acumulou uma extensa experiência prática sobre tecnologia da madeira. Mas, por tradição, na época esses especialistas eram extremamente convictos e orgulhosos de suas habilidades e conhecimentos, ao mesmo tempo que se mantinham conservadores, acreditando mais nas soluções que aprenderam e já haviam testado. Nessa época era visível um fenômeno típico dos períodos de transição na indústria, um conflito entre as questões de qualidade artesanal e qualidade industrial. Os anos seguintes demonstrariam que esse era um falso conflito, muitas vezes exacerbado por setores interessados no design, mas eventualmente, pouco próximos de sua prática real. Na própria ESDI era comum um tipo de discussão contrapondo o artesanal ao industrial, discussão em que quase sempre, de ambos os lados, prevaleciam argumentos autoritários de um lado e emocionais do outro.

A distinção entre esses dois tipos de qualidade ocorreu com o próprio desenvolvimento de um processo de produção e de intercâmbio de conhecimentos ocorrido principalmente a partir da década de 1980. A distinção das qualidades, artesanal e industrial, permitiu a justa avaliação de cada uma, sua comparação crítica e não emocional e, finalmente, uma positiva interação entre elas, até mesmo em setores nunca pensados como viáveis para essa ocorrência como o próprio mobiliário para escritórios. Uma das eventuais consequências positivas do pensamento globalizado na indústria foi a quebra de uma barreira ideológica estabelecida pelo design moderno quanto à possibilidade de agregar qualidade vinda de uma tradição mais artesanal a uma produção seriada de maior escala.

Houve evidentemente, nessa interação, uma sensível modificação no sentido do que significaria a qualidade artesanal. Isso não é apropriação indébita, nem traição a ideais fundamentalistas. Ao contrário, foi uma atitude progressista e criativa que permitiu a saída do território do confronto para outro que admite a existência de dois tipos distintos de qualidade e, além disso, sua permeabilidade, fato evidenciado e consequência direta de sofisticados processos industriais que, não poucas vezes, recuperaram e desenvolveram antigas técnicas 
Qual é a vantagem de um móvel desmontável? Essa poderia ser uma dúvida comum aos consumidores das décadas de 1950 e 1960. Já para o fabricante a questão era clara: a fabricação de tampos, estruturas, gaveteiros e outros componentes era e ainda é processada em lugares diferentes com equipamentos também diferentes. Até o acabamento desses componentes é feito ainda antes da montagem final, e assim, eles são muitas vezes embalados, identificados e empilhados enquanto aguardam o despacho. O volume ocupado pelo móvel fica sensivelmente reduzido o que torna o transporte mais econômico e seguro.

Quando se raciocina em função de programas de móveis, a desmontabilidade ganha ainda outra importância, pois muitos dos componentes tornam-se intercambiáveis entre os diversos programas. Uma empresa que trabalhe com essa concepção deverá sempre planejar a fabricação de um número controlado de componentes, de acordo com o número de produtos finais a serem produzidos.

Mesa MM desmontada, 1968 e soluções consideradas superadas. Mas, na época, no tempo do confronto, a reação do Sr. Vicente às propostas de Bergmiller era a mesma que eu havia observado quando estagiei na Escriba: um sonoro "no va dar". Havia um problema a ser resolvido e o confronto não era o caminho para isso. Muitas vezes ganhar uma disputa significa perder alguma coisa que, nesse caso, não poderia ser dispensada impunemente. A Escriba se desenvolvia, mas ainda dependia de soluções que não eram artesanais, porém deveriam ser observadas a partir de uma ótica que incluísse uma noção de qualidade apurada, característica que o Sr. Vicente possuía. Ao "no va dar" Bergmiller apresentou uma contraproposta: "O senhor faça o teste do que eu proponho e execute em paralelo a sua ideia". Lembro-me muito bem dos testes de juntas que executei junto com Vicente. Desenvolvíamos os protótipos dessas juntas para depois forçá-las até o limite, quebrá-las e, a seguir, tirar as conclusões. Era necessária uma extrema atenção pois não se tratava de testes técnico-científicos executados numa banca de provas, mas testes mais simples, menos elaborados, mas que deveriam ser também indicativos e conclusivos a respeito de sua eficiência. Quase sempre prevaleceram as propostas de Bergmiller. Em pouco tempo, Vicente habituou-se a respeitá-lo. Durante muitos anos seguintes trabalharam juntos, em harmonia, num processo criativo conjunto. $\mathrm{O}$ "no va dar" tornou-se um dia uma brincadeira interna na Escriba e fora dela, em outros trabalhos que desenvolvemos. A citação dessa frase em portunhol sempre significava que estávamos tentando alguma coisa nova, alguma coisa criativa.

Ainda no tempo em que era aluno de Bergmiller na ESDI, ouvi-o dizer que seria comum um profissional de fora enfrentar dentro de uma empresa, por parte de funcionários estabelecidos e mais antigos, reações contrárias aos objetivos de um projeto que alterasse substantivamente qualquer ordenamento já estabelecido. Ressaltava a importância de aprender com isso e saber enfrentar com tato e sensibilidade qualquer divergência. $O$ importante seria ganhar um colaborador, um participante ativo e interessado no projeto. Quando fui estagiar na Escriba e fui posto a trabalhar com Vicente, entendi logo por quê.

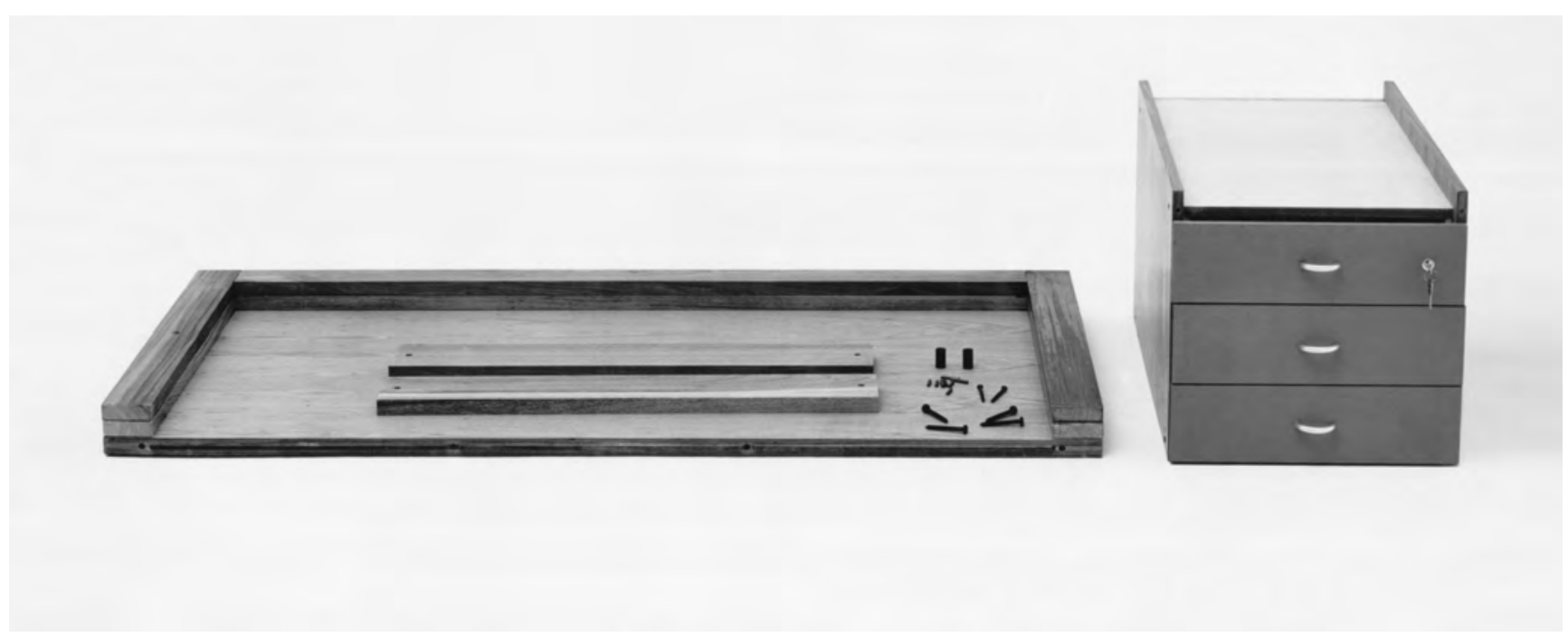



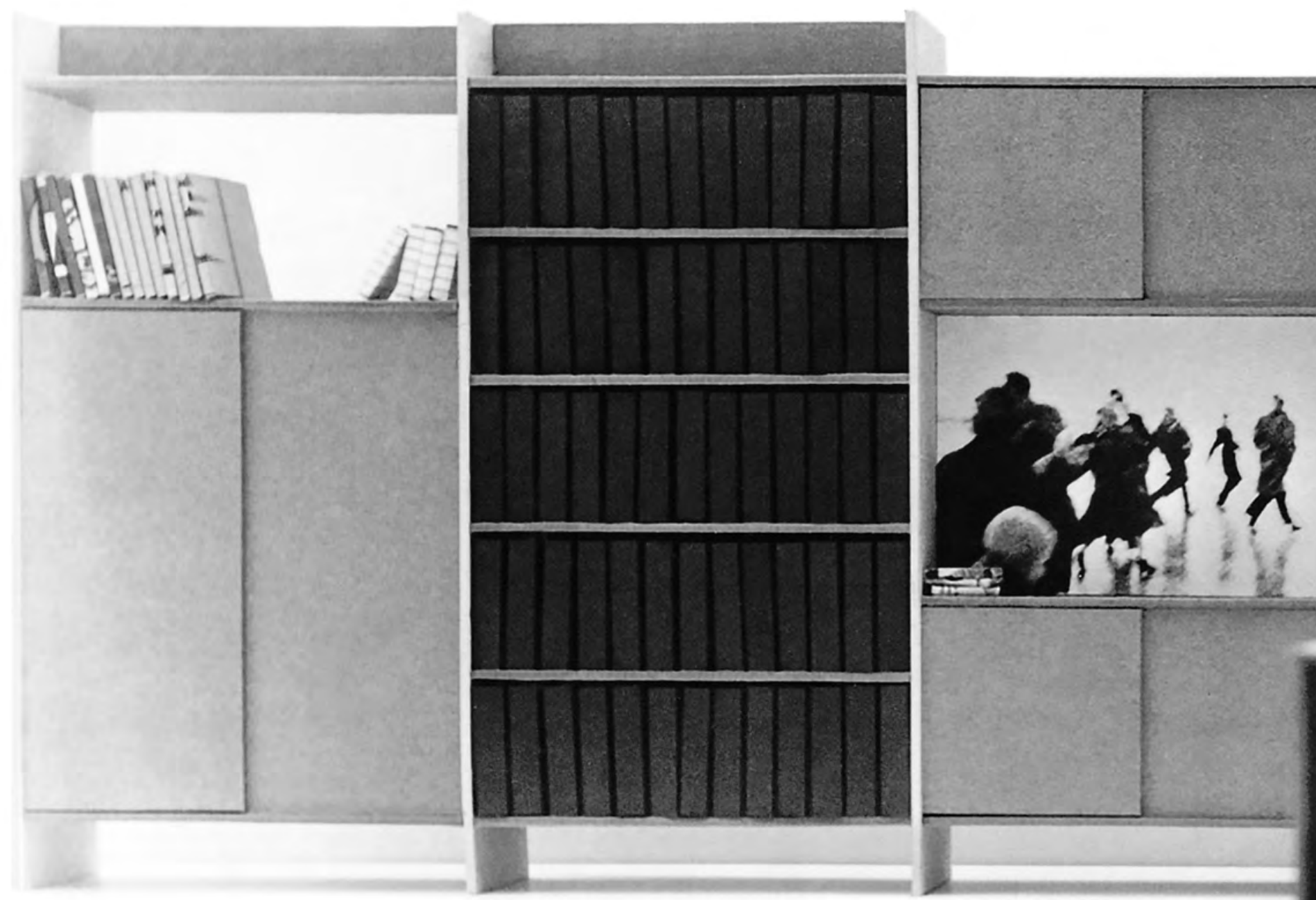
A Escriba evoluiu muito a partir da década de 1970, tanto na oferta de produtos como no faturamento. No mercado de mobiliário para escritórios, ajudou a definir um design brasileiro e também o significado de um produto de qualidade. Nunca houve o objetivo de se criar um estilo. Mas todos os móveis tinham características semelhantes, estabeleciam relações entre si e faziam parte de um conjunto harmônico. Os programas da Escriba apresentavam uma personalidade muito clara e definida: eram econômicos e estritamente funcionais e racionais, sem concessões nos mínimos detalhes. Lembro-me de ter executado, nas oficinas da ESDI, os puxadores para as gavetas dos protótipos da nova linha em 1972. Interpretei equivocadamente um desenho esquemático e a seção do puxador foi executada em forma quadrada em vez de redonda. Não havendo tempo para refazê-los, os gaveteiros foram montados com esses puxadores e quase todos afirmaram ter gostado mais dos elementos com seção quadrada. Bergmiller ouviu a todos pacientemente e depois emitiu sua opinião: poderia até aceitar que todos preferissem os puxadores quadrados, mas essa era apenas uma preferência estética, um juízo subjetivo e não o que havia sido estabelecido como conceito geral do móvel, baseado num juízo crítico e racional. Iria prevalecer o conceito. Aos pouco se foi estabelecendo o conceito geral da Escriba, onde um simples detalhe deveria ter a mesma atenção dada a qualquer outro aspecto que fizesse parte do projeto. Essa postura foi gradualmente implantada e observada nos catálogos, na publicidade, na linguagem da empresa e na sua presença em feiras e em suas lojas e showrooms.

Nessa altura, a Escriba já havia se mudado da oficina na rua Tapabuã na capital, para uma construção projetada e planejada em Taboão da Serra, cidade próxima a São Paulo, com instalações e máquinas de última geração. O layout da nova fábrica evidenciava a coerência buscada entre design, produto e produção. Um sistema de produtos bem pensado resulta num processo de fabricação claro, limpo e ordenado, que induz e facilita o controle permanente da qualidade. Nessa nova fábrica tornou-se também mais fácil a reunião dos responsáveis pelo planejamento, pelo design, pela produção e pela venda dos produtos. Assim se criou um "comitê de design", muito antes de se ter estruturado um departamento específico de design. O design tornou-se um argumento da Escriba, tanto no plano interno quanto em sua comunicação com públicos específicos e genéricos. Buscou-se também uma linguagem e uma forma gráfica que contribuísse para o esclarecimento do consumidor e do usuário. Bergmiller afirma que poucas empresas brasileiras colocaram o design como conceito tão importante para si mesma. E diz ainda: "Qual foi o segredo do sucesso dessa política empresarial voltada para o design? Eram sempre medidas e decisões sensatas, equilibradas, que se baseavam em baixos investimentos e no desenvolvimento de uma tecnologia própria. Essa atitude gerou confiança e segurança. Gerou uma competência para enfrentar e resolver qualquer demanda do mercado".

Na década de 1950, o paulista ostentava grande orgulho quanto ao crescimento de sua cidade e acreditava em frases do tipo "São Paulo é a cidade que mais cresce no mundo" ou "São Paulo não pode parar". Poucos, ninguém 
mesmo, avaliava as consequências futuras dessa atitude. Crescimento para nós era uma referência quantitativa. A implementação de critérios de qualidade não era difícil apenas na produção industrial e mesmo as soluções urbanas projetadas visavam facilitar e acelerar esse crescimento desenfreado. Isso representava apenas mais uma evidência de certa tradição política do país: o uso dos recursos públicos em benefício exclusivo dos interesses imediatos da elite. Nas grandes artérias urbanas, debaixo dos grandes viadutos e das grandes vias marginais ou perimetrais que facilitavam o trânsito, começavam a se multiplicar os bolsões de miséria e exclusão. Tudo era justificado, como sempre, com promessas de um futuro melhor, e esse era o argumento capaz de cegar principalmente uma classe média incipiente que, notadamente, em São Paulo e no Rio de Janeiro, pensava estar na frente de uma corrida rumo ao Primeiro Mundo. Ainda na década de 1970, Octavio Paz faria uma interessante observação a respeito dessa atitude típica dos países chamados então de Terceiro Mundo no ensaio "Invenção, subdesenvolvimento, modernidade", publicado em Signos em Rotação (Perspectiva,1971). Com extrema propriedade, ele disse que todos se empenhavam em uma exaustiva corrida para ver "quem chegaria primeiro ao inferno".

Nessa época, José Serber perguntou a Bergmiller como a Escriba deveria evoluir. A empresa já tinha então uma dimensão respeitável em comparação com suas concorrentes. Diz Bergmiller: "A minha posição era firme: a Escriba deveria empenhar-se, de forma permanente, em melhorar seus produtos, racionalizar os programas em oferta, aperfeiçoar os processos de fabricação, enxergar, entender e definir a sua faixa de mercado e atuar principalmente em função dela. Uma parte fixa da produção deveria ser destinada à exportação, mas o mercado interno deveria ser a base de sustentação da empresa." As oportunidades para a exportação de mobiliário de escritório brasileiro eram promissoras e baseavam-se em duas premissas principais: matéria-prima relativamente abundante e mão de obra barata. A exportação era, de fato, uma imposição econômica, até porque a permanência de uma política de concentração de renda não admitia a formação de um mercado interno forte e, se uma indústria tivesse como objetivo o próprio crescimento, teria de buscar mercado no exterior, em países onde esses tipos de trabalho de baixo custo já estivessem reduzidos ou então muito mais caros que nos países periféricos. Deve-se frisar que todo esse panorama é anterior à revolução da informática, à introdução dos computadores no cotidiano das empresas e, principalmente, dos microcomputadores na vida de um razoável número de pessoas das classes mais favorecidas. Esses fenômenos, que ocorreram na década de 1980, viriam a alterar dramaticamente a demanda qualitativa do mobiliário para escritório.

Os produtos tiveram de alterar sua configuração tradicional e quem não estava preparado para a assimilação dessas mudanças perdeu seu espaço vital. Depois de 1990, pode-se dizer que o projeto conceituado a partir da madeira como matéria-prima principal, e que contava com uma hipótese de mão de obra menos qualificada, não apresentou mais quaisquer condições de concorrência no mercado externo, pois o que antes era um fator de custo baixo passou a ser o oposto. As próprias fábricas e seus processos sofreram mudanças radicais, crescendo a 
Poltrona para auditório PAR2, 1980

Colaborador: Lula Heim Bittencourt terceirização de componentes e outros elementos do mobiliário. A ideia de sistema ou, como era chamada na Escriba, programas de móveis, integrados e versáteis, permitiu uma dura sobrevivência àqueles que tinham, pelo menos, adotado um comportamento mais planejado e racional. Mas houve ainda, no início da década, a abertura econômica para a importação e para a instalação no país de novos fabricantes, muitos deles mais bem preparados para esse tipo de mercado. Assim, além de ter seus horizontes na exportação muito prejudicados, a indústria nacional passou a ter competidores de peso até no mercado interno. Esse mercado ainda teve outras influências negativas como a grande retração do principal consumidor interno que era o próprio poder público.

Todas essas considerações reconduzem a narrativa ao momento em que José Serber perguntava a Bergmiller sobre o futuro da Escriba. Quando Bergmiller afirmava a importância de uma atitude racional queria dizer ainda que jamais a preocupação da empresa deveria estar concentrada em fatores quantitativos, de crescimento medido pelo tamanho, pelo investimento em número de equipamentos e de pessoal. Ele se referia sempre à necessidade de saber planejar, fabricar e comercializar sob controle, de modo que todos pudessem ter uma atitude mais tranquila, contribuindo, brincava, até para a saúde pessoal dos dirigentes da empresa. Dizia ainda que "produzir alguma coisa de que se

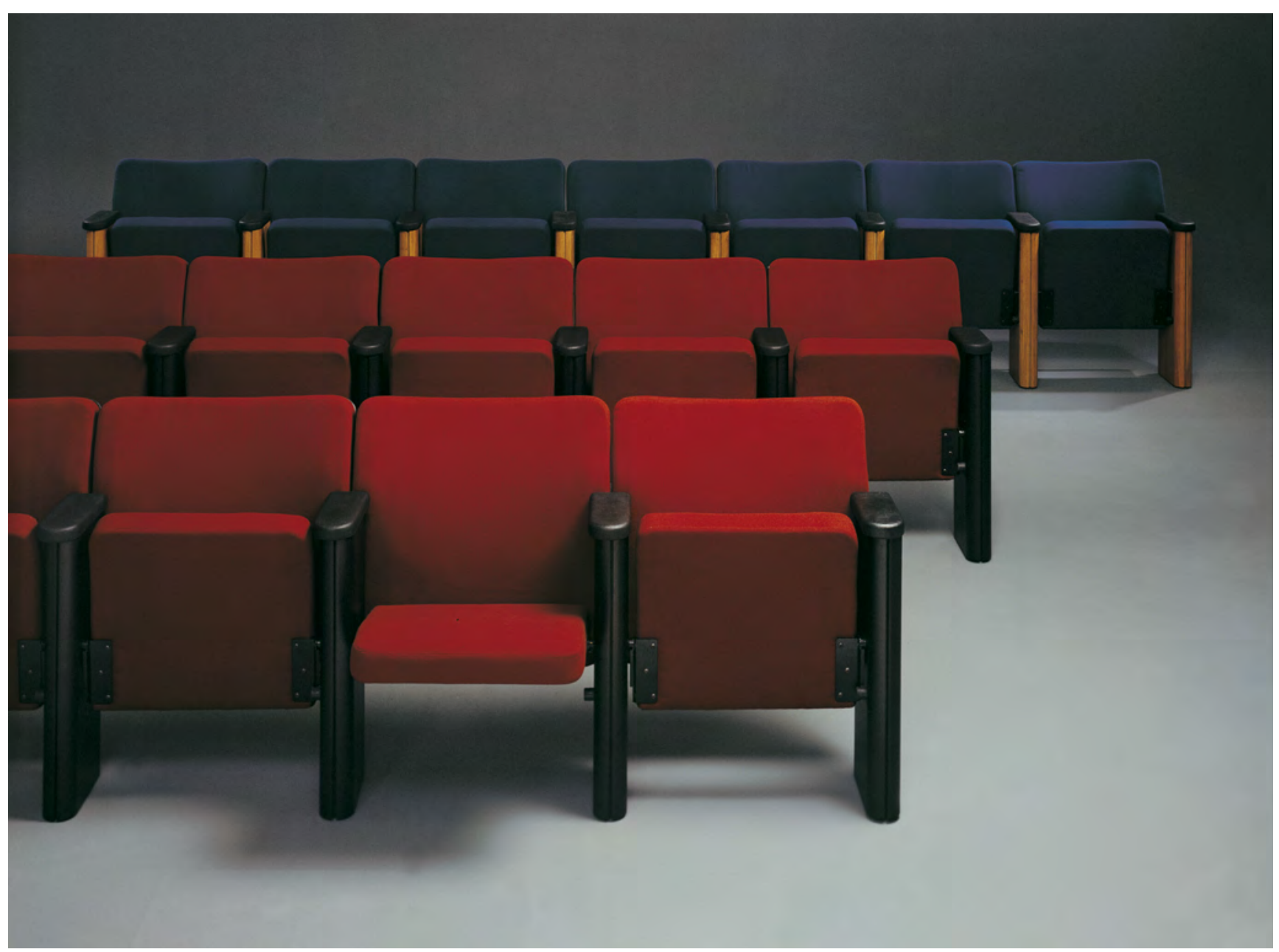


Poltronas para auditório só podem ser fabricadas em grande escala. São produtos requisitados pelas salas de espetáculo, empresas e corporaçóes para instalar seus auditórios e salas de treinamento. Isso as torna um projeto interessante para investir em desenvolvimento, produção e comercialização. Demandam processos e técnicas especificas e, na época, deveriam ser projetadas levando em consideração a viabilidade de sua fabricação nas instalaçôes da empresa. Mesmo sendo um tipo de mobiliário com características muito definidas, deveriam ter os mesmos critérios dos demais programas de móveis da empresa. São muitos os dados considerados num projeto de poltrona para auditório: $t i-$ pologia dos auditórios, exigências funcionais e ergonômicas, conforto, visibilidade, acústica, segurança, montagem em linhas retas ou curvas, assento rebativel, prancheta escamoteável, sistemas de tradução simultânea integrados, luz de vigia, montagem no piso. A solução desenvolvida apresentou um resultado bastante eficiente, simples e racional, acima de tudo confortável e com um preço de mercado bastante compativel com suas qualidades. tem orgulho; não existe nada melhor". Porém, ele mesmo refletindo sobre esse fato lembra: - "Talvez essa tenha sido uma resposta minha dentro de uma mentalidade alemã, acostumada a crescimentos em ritmos mais equilibrados, bem calculados." O economista José Serber balançou a cabeça e não apresentou nesse momento um contra-argumento racional. Recordo-me só de um "sabe, no Brasil o crescimento é difícil de controlar..."

Nessa época ainda era viável a ideia de desenvolvimento acelerado. Posteriormente, o regime militar imposto em 1964 daria prosseguimento a esse processo sob o nome de "milagre econômico brasileiro". Aos investimentos do Estado correspondiam crescimentos em setores específicos; pouco desenvolvimento social; praticamente nenhum crescimento sustentado da renda média do brasileiro. Esse cenário era comum em muitos países em desenvolvimento e, sabe-se tão bem hoje, apoiado em um grande endividamento externo que, de resto, não pode ser atribuído apenas aos regimes militares. A ausência da ideia de planejamento sempre foi característica de nossos períodos de crescimento. Mitificam-se as "metas" do período JK, assim como também o regime militar mitificou um Ministério do Planejamento ainda que nele tenham atuado personalidades do porte de um Roberto Campos e do Dr. Otavio Gouveia de Bulhões e, posteriormente, João Paulo dos Reis Velloso, Antonio Delfim Neto e Mário Henrique Simonsen. Esses nomes, somados aos do período JK, como Lucas Lopes, Walther Moreira Salles e Celso Furtado, comporiam um invejável conjunto de mentes tão competentes quanto criativas. Em um ideário conservador era o que de melhor o país poderia apresentar e, se nada aconteceu do ponto de vista do desenvolvimento sustentado, certamente não se pode atribuí-lo a qualquer tipo de despreparo técnico ou intelectual de seus dirigentes. Talvez, depois do grande mergulho no vazio do governo João Figueiredo, ao final do regime militar, tenha ficado mais claro para todos que o modelo desenvolvimentista que, até então tinha sido priorizado no país, tinha também atingido seus limites extremos e não era mais funcional.

Em suas reflexões específicas sobre a Escriba, Bergmiller continua: Sem ser teimoso, continuo ainda hoje fiel aos meus argumentos daquela época. Vivendo muitos anos no Brasil, compreendo melhor muitas coisas hoje. Seria utópico imaginar programar-se para prazos muito extensos. Mudanças politicas e suas consequências econômicas sempre influenciaram as atividades produtivas no país que, aliás, passou nessas quatro últimas décadas por muitos altos e baixos. O empresário brasileiro inteligente aprendeu a agir nas turbulências da inflação, nas mudanças de moeda, nos confiscos de capital e nas incertezas políticas. Aprendeu a tomar decisóes rápidas, correr riscos maiores que na maior parte do mundo e nem sempre tinha tempo para aprofundar maiores análises, para estruturar um tipo de planejamento ordenado e racional. Também aprendi um pouco dessa dinâmica, inclusive a resolver problemas pulando estágios que me pareciam necessários. Mas sempre estive ciente de que a responsabilidade final nesse processo seria minha. 
Mesa para informática, 2002. design Bergmiller | JR Calejo Conforme publicado em catálogo. Projeto gráfico: Warrak Design
Os elementos de análise aqui utilizados poderiam conduzir a uma ideia pessimista. Guardo-a. Bergmiller recusa a ideia de pessimismo e, com bastante objetividade, diz: "O primeiro acordo de colaboração, em 1967, estendeu-se por mais de trinta anos. Esse simples fato representa um dado positivo e provavelmente inédito: que uma empresa brasileira esteja dando continuidade a um programa baseado no design por um período tão extenso. "Foi esse fator que permitiu, inclusive, à Escriba estabelecer contatos e colaboração com empresas do exterior como a Wilkhahn, exportar e ter representações nos Estados Unidos e na Europa e, no plano interno, preocupar-se inclusive com sua inserção no plano social através de projetos de natureza informativa e cultural."

Ainda sobre as questões ligadas ao projeto de mobiliário para escritório é interessante citar observações de Bergmiller que podem ajudar a refletir sobre as relações entre estado e setor produtivo, em grande parte de seu trabalho na Escriba. Ele sempre lembra uma questão muito controvertida que foi o estabelecimento pelo estado de um padrão para o mobiliário dos escritórios oficiais, no fim das contas, o maior segmento consumidor desses produtos por longos anos.

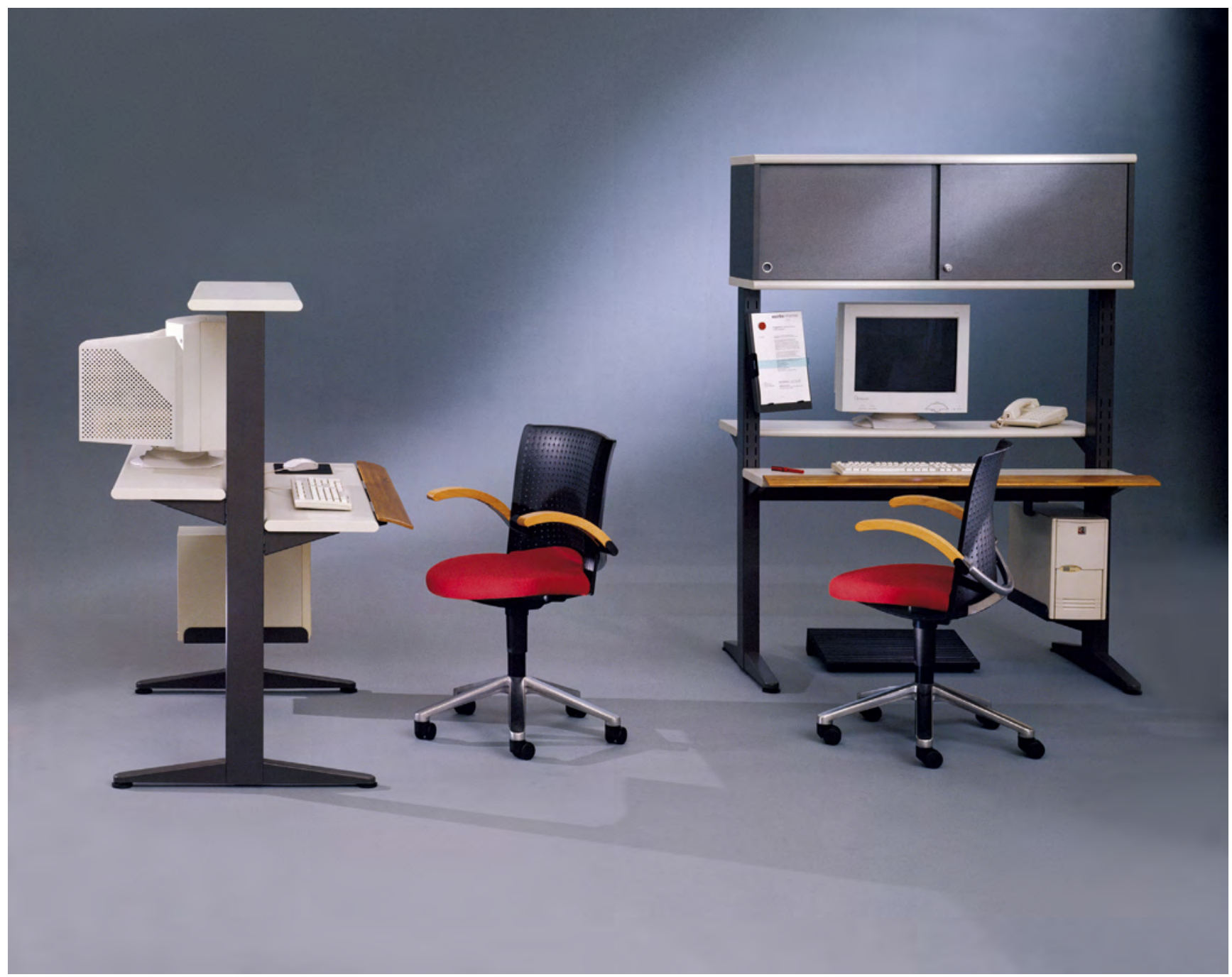


O Congresso do Fundo Monetário Internacional FMI realizou-se no Rio de Janeiro em 1967, usando parte das dependências do Museu de Arte Moderna do Rio de Janeiro, ainda inacabado. Os recursos recebidos pelo MAM para a realização do congresso permitiram a conclusão de sua sede definitiva no Parque do Flamengo no ano seguinte.

Os recursos informatizados surgiram no cotidiano dos escritórios a partir do uso dos microcomputadores na década de 1980. Desde então sua expansão foi notável. Hoje as recomendaçôes relativas à saúde do trabalho e ergonomia para escritórios já incluem normas relativas a esse tipo de produto. Os próprios microcomputadores evoluiram, acrescentando a seu design algumas regulagens antes inexistentes e que tinham de ser compensadas no projeto do mobiliário de suporte. Por outro lado, o computador não era mais visto como um simples sucedâneo da máquina de escrever.

A mesa para informática incorporou esses conceitos. A característica principal do móvel consiste na possibilidade de regulagem da superficie de trabatho e da superficie de suporte para o monitor, através de cremalheiras. A mesma coluna regulável da estante para bibliotecas foi utilizada. Existe um apoio para os punhos, suporte para CPU, porta-texto, conjunto de tomadas com calhas para os cabos e apoio para os pés. Todas as regulagens podem ser feitas sem manivelas, pistôes ou motores. A informática fica cada vez mais sofisticada, mas o móvel de suporte pode e deve permanecer um produto lógico, simples e elementar, até mesmo por que as demandas da informática transformam-se muito rapidamente.
Segundo ele: "Em fins dos anos sessenta o governo militar decretou a linha FMI para seu mobiliário de escritório. Todas as repartições públicas federais deveriam utilizar esse padrão. A linha FMI, como ficou conhecida, foi resultado de um levantamento do mobiliário de escritório produzido no Brasil nos anos 1960. O Congresso do FMI deveria realizar-se no Rio de Janeiro, no Museu de Arte Moderna que assim seria concluído. Mas era necessário equipar e mobiliar o museu. O levantamento serviu para definir os critérios de licitação para a compra do mobiliário e foi realizado pelo Ministério da Fazenda. Depois o governo considerou oportuno adotar os mesmos padrões em todas as concorrências públicas a serem realizadas dali em diante. Os critérios de design e de qualidade formal foram ignorados. As indústrias que tinham seus próprios programas, que investiram em desenvolvimento e em pesquisa próprias e em produtos melhores e diferenciados qualitativamente protestaram e resolveram formar uma associação de fabricantes de mobiliário para escritório com o objetivo principal de enfrentar organicamente o decreto do governo, expondo e defendendo argumentos racionais. Em vão. Por muitos anos, durante o regime militar, a linha FMI foi a única opção que podia ser especificada em licitações públicas e as empresas mais avançadas ficaram de fora, pois não era razoável e nem econômico manter duas linhas diferenciadas de produção. $\mathrm{O}$ poder público era o grande consumidor interno de mobiliário para escritório e para isso poderia e deveria, sim, estabelecer critérios rígidos de licitação. Mas tais critérios deveriam ser dirigidos especificamente às características de uso, às especificações técnicas, definir padrões ergonômicos, indicar os limites de valores e os prazos de entrega e garantia. Estabelecer normas formais, estilísticas, limitar as opções de materiais e acabamentos foi uma atitude totalmente errada que significou um problema e um atraso conceitual na indústria de mobiliário para escritório. Impossibilitava qualquer sentido de inovação. Até hoje em Brasília, pode-se observar uma notável incoerência entre a arquitetura e as instalações nos prédios públicos. Enquanto o conceito arquitetônico representa algo inovador, que inclusive foi objeto da atenção no mundo todo, as instalações eram e são ainda hoje, rudimentares, salvo as decorações de alguns palácios. "Nas comissões de licitações públicas deveriam participar designers, tanto para elaborá-las de forma sensata, como para opinar e julgar adequadamente as questões de uso e formais dos produtos."

Talvez seja oportuno lembrar um fato ocorrido em 1982, quando organizamos uma exposição comemorativa dos vinte e cinco anos de atividade da Escriba. Nessas ocasiões sempre trabalhávamos juntos, Bergmiller, Goebel Weyne e eu. Cada um tinha suas atribuições específicas, mas normalmente todos opinavam sobre tudo. Elaborei nessa época um slogan para todas as comemorações e Goebel fez um belíssimo cartaz com a frase:

"Escriba: 25 anos de ideias no lugar".

Penso que essa frase sintetiza com clareza o que significava o trabalho desenvolvido por Bergmiller na empresa. 
Quando se pensa em móveis para hotéis imaginam-se camas, criados-mudos, bancos-maleiros, uma mesa, duas cadeiras, etc. Mas hotéis não são muito diferentes de empresas: têm uma recepção equipada com balcões, sofás para espera, uma administração equipada com móveis de escritório, restaurantes, bares, cafés, salas de reuniões e de convenções. Todos esses componentes já eram fabricados pela Escriba e isso representava cerca de $50 \%$ do inventário de um hotel. 0 restante era constituído pelo mobiliário dos

"Escriba: 25 anos de ideias no lugar". Design GOEBEL WEYNE quartos para hóspedes.

Assim como nos móveis para escritório, adotou-se o comportamento modular no projeto dessa linha, incluindo-se nessa ordem até mesmo o espelho e o banco-maleiro. Cama e criado-mudo são acoplados em módulos que são encaixados num perfil de madeira preso à parede. É possível assim individualizar as camas ou transformá-las em cama de casal apenas deslizando-as nesse perfil. Atrás do perfil correm as instalações elétricas, telefônicas e outras necessárias. Projetou-se especialmente uma linha de colchas para os quartos, através de um programa de permutação gráfica que as tornava peças únicas, sugerindo-se evitar assim o hábito de decorar os quartos com gravuras de gosto duvidoso.
Linha de móveis para hotéis, c.1975 


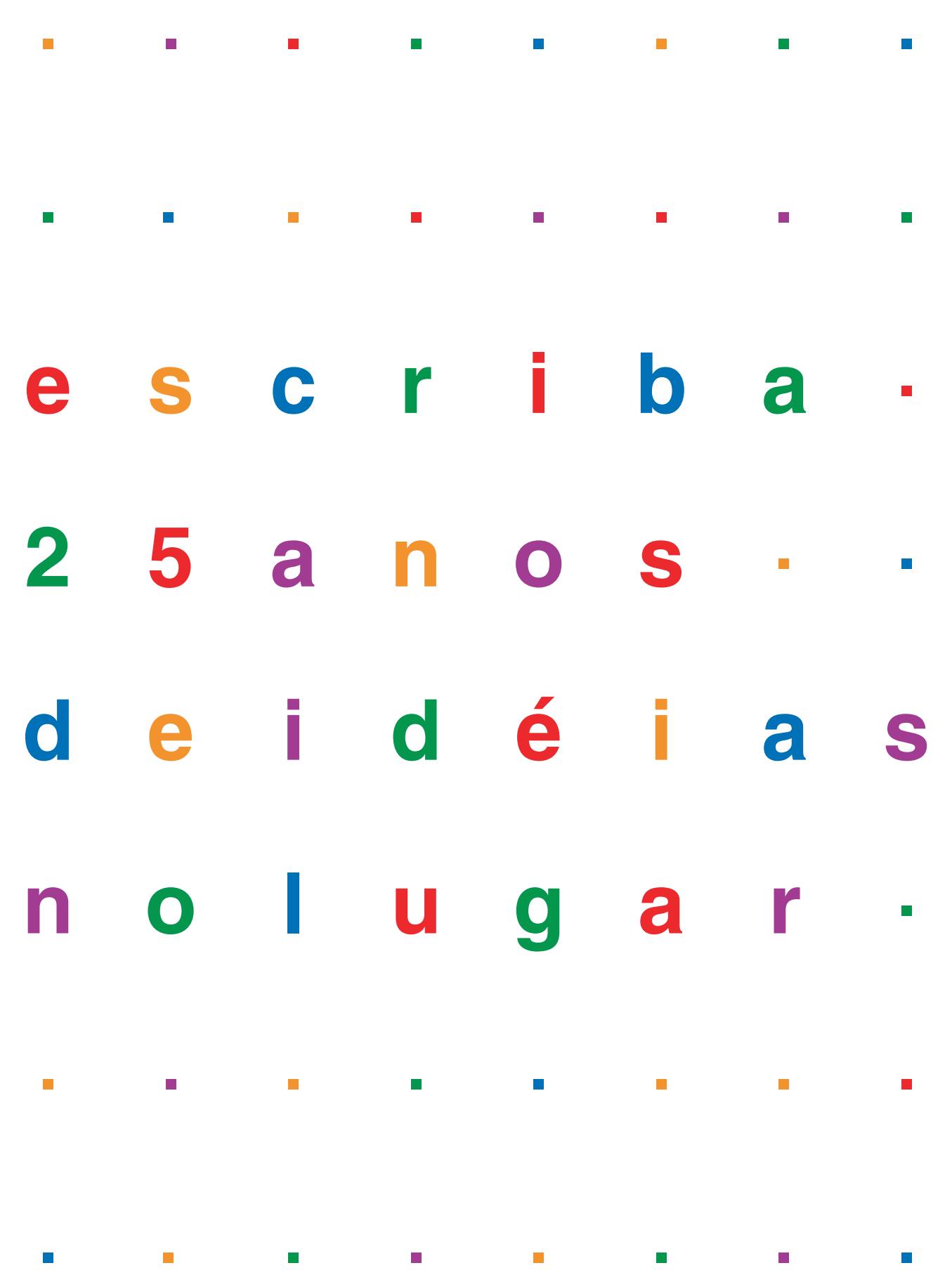



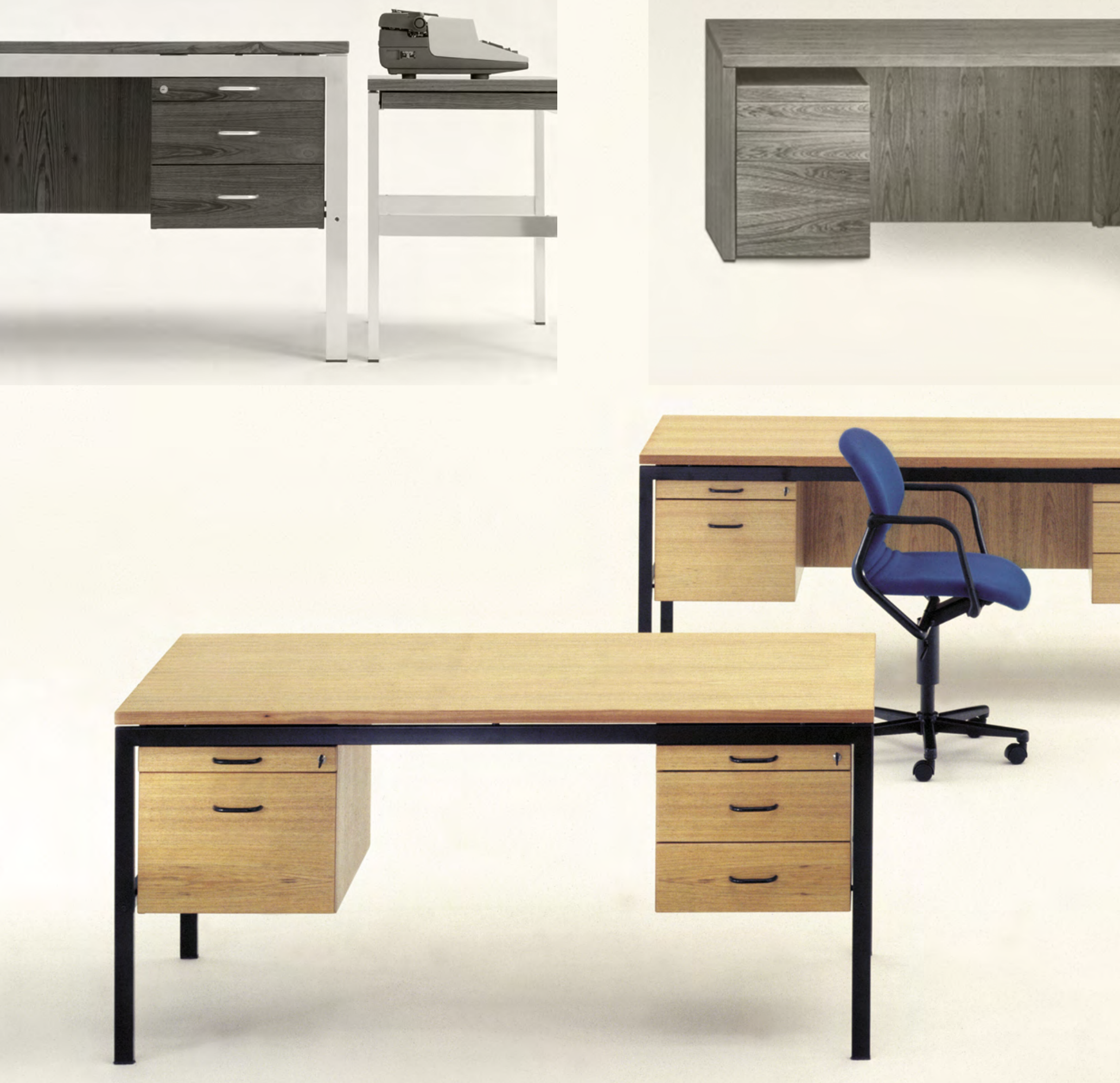
Mesas para escritório, 1972

Mesa MF com estrutura em aço tubular retangular pintado.

Mesa MM com estrutura em madeira maciça.

Mesa MA com estrutura em tubo de alumínio retangular anodizado.

Mesa MP com estrutura em painéis de aglomerado.

Mesa MO para reunião, 1987

As reuniões de trabalho passaram, cada vez mais, a fazer parte do cotidiano dos escritórios. Esta mesa (com estrutura tubular redonda) foi projetada como um sistema construtivo que facilitava até mesmo a fabricação de um móvel especial sob medida.

\section{Mesa MO}

com computador coletivo, 1988 O mobiliário para escritório sempre acompanhou a evolução tecnológica do próprio trabalho e sua disponibilização. No Programa MO monitor e teclado eram colocados em um dispositivo giratório, para um uso coletivo, numa época em que o computador ainda era um produto caro, que estava sendo introduzido no dia a dia de um escritório.
O termo superfície de trabalho surgiu com a evolução do conceito do espaço funcional e das atividades nele desenvolvidas. Evolução que gerou uma nova nomenclatura para o mobiliário de escritório. Da mesma forma que escrivaninhas foram definidas como superfícies, cadeiras e poltronas giratórias passaram a se chamar assentos de trabalho. Elementos suspensos, volantes e painéis intercambiáveis são outros nomes que identificavam novos produtos. A este conjunto antes contido entre quatro paredes deu-se o nome de posto de trabalho.

A Escriba lançou sua primeira linha de superfícies de trabalho em 1962. Era a linha Escriba, composta de escrivaninhas e mesas em várias dimensões, com tampos em jacarandá e estruturas em alumínio ou ferro pintado. Este lançamento que incluía armários produzidos com o mesmo material, um ano depois recebeu o Prêmio Boa Forma. Dez anos depois do primeiro lançamento, a Escriba apresentou ao mercado um novo conjunto de móveis, mais aprimorado e mais versátil: os programas MA, MF, MP e MM.

Programa era o conceito básico do desenvolvimento dos produtos na Escriba. Seu sentido era análogo ao de sistema, ou seja, conjuntos de elementos que estabelecem relações entre si e com o todo. Cada programa de móveis era um conjunto consistente e todos os programas estabeleciam também relações entre si. A idéia de programação do espaço do escritório e de atender ordenadamente a todas as demandas do trabalho nele desenvolvido eram as referências do projeto geral da empresa. O termo programa sintetizava essa diretriz. Cada programa recebia uma codificação que servia não só para a produção interna, como também para a identificação dos produtos em sua fase de comercialização e montagem.

Os quatro programas de mesas para escritório usavam os mesmos tampos, gaveteiros, volantes e demais acessórios para todos os seus produtos. Suas estruturas eram diferentes podendo ser em tubo de aço pintado, alumínio anodizado, madeira maciça ou painéis de aglomerado. Existia assim a variedade mas prevelecia uma unidade tornando fácil a identificação do conjunto. Esses programas representavam um fator de racionalização tanto na fabricação, como na comercialização e no planejamento dos escritórios.

O programa MO utilizava estrutura metálica e pés em tubos de aço redondos pintados e cores variadas. Seus componentes eram também coordenados com os outros programas de mesas possibilitando uma integração. Os tampos das mesas podiam ter revestimento em laminado melaminico ou folhado em madeira, com encabeçamento em PVC. Por suas caraterísticas técnicas esse programa possibilitava soluções flexíveis e opções variadas com gaveteiros fixos, mesa para datilografia acoplada e painel frontal. Incluía tampos conectáveis para a formação de superfícies como as mesas para terminais de vídeo e impressoras. Podia ainda ser usado com tampos em formas diferentes para a formação de mesas de reunião. 
Mesa MO para reunião, 1987

Bergmiller | Paulo Cesar Germani

Conforme publicado em catálogo

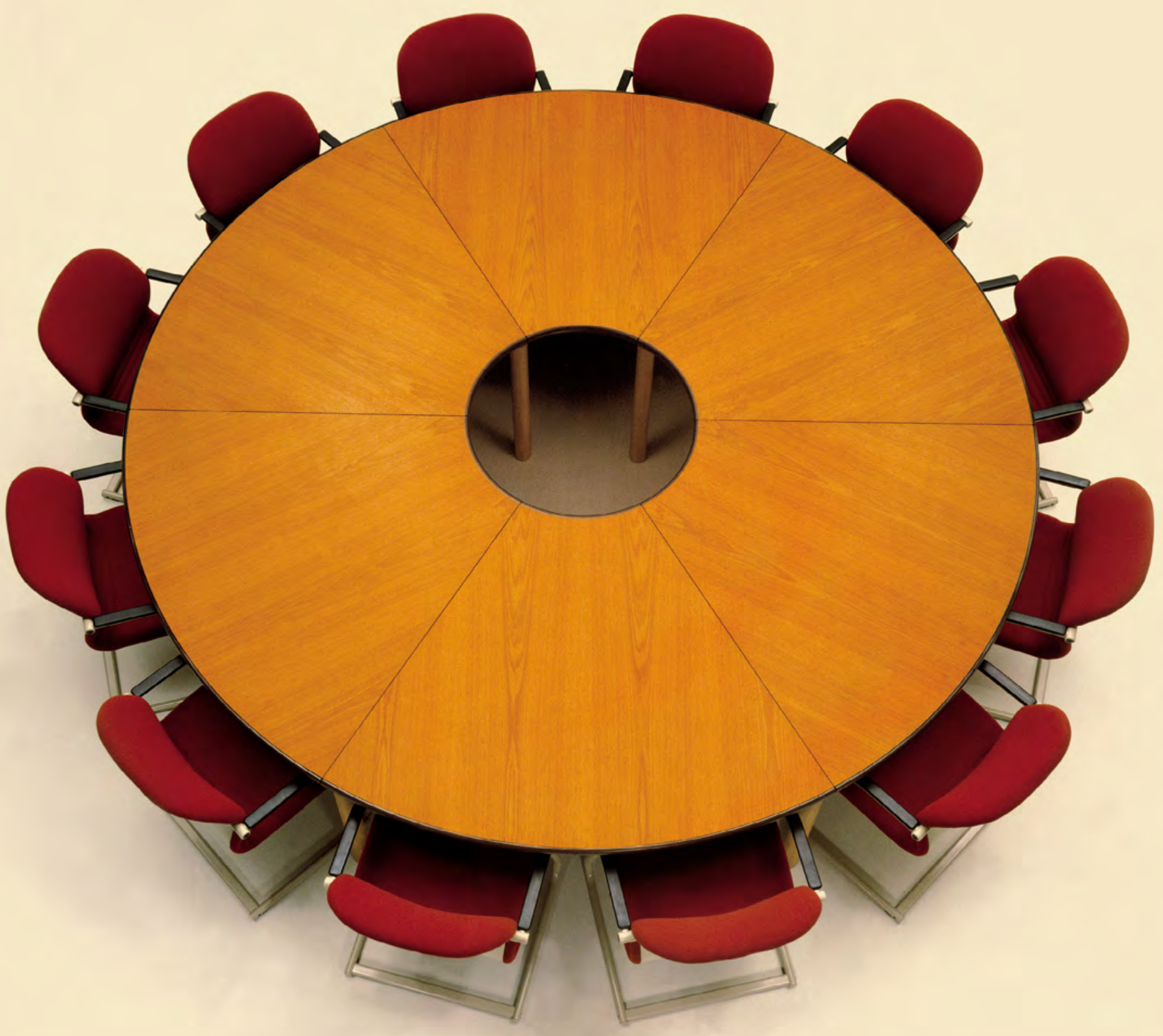




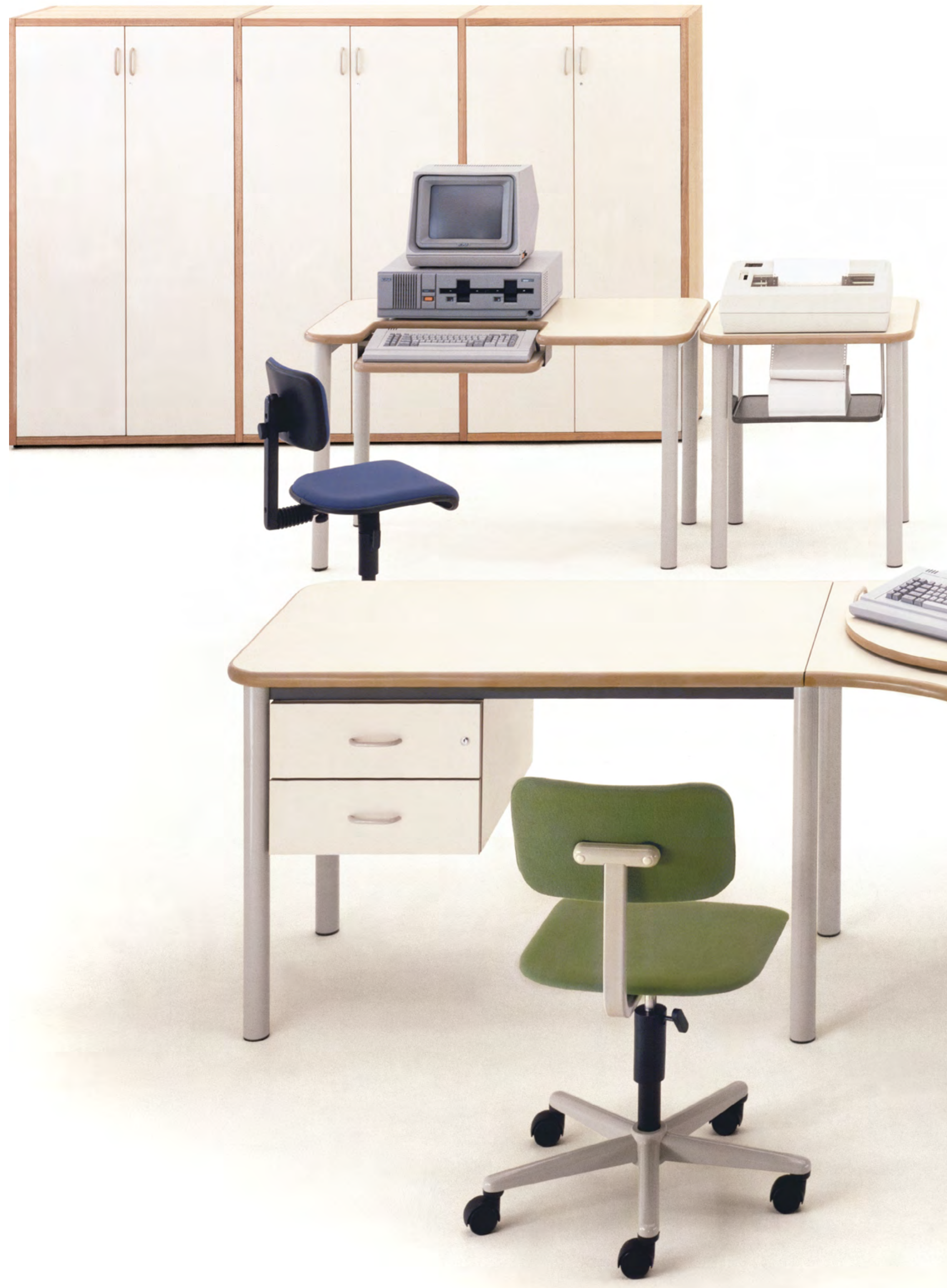




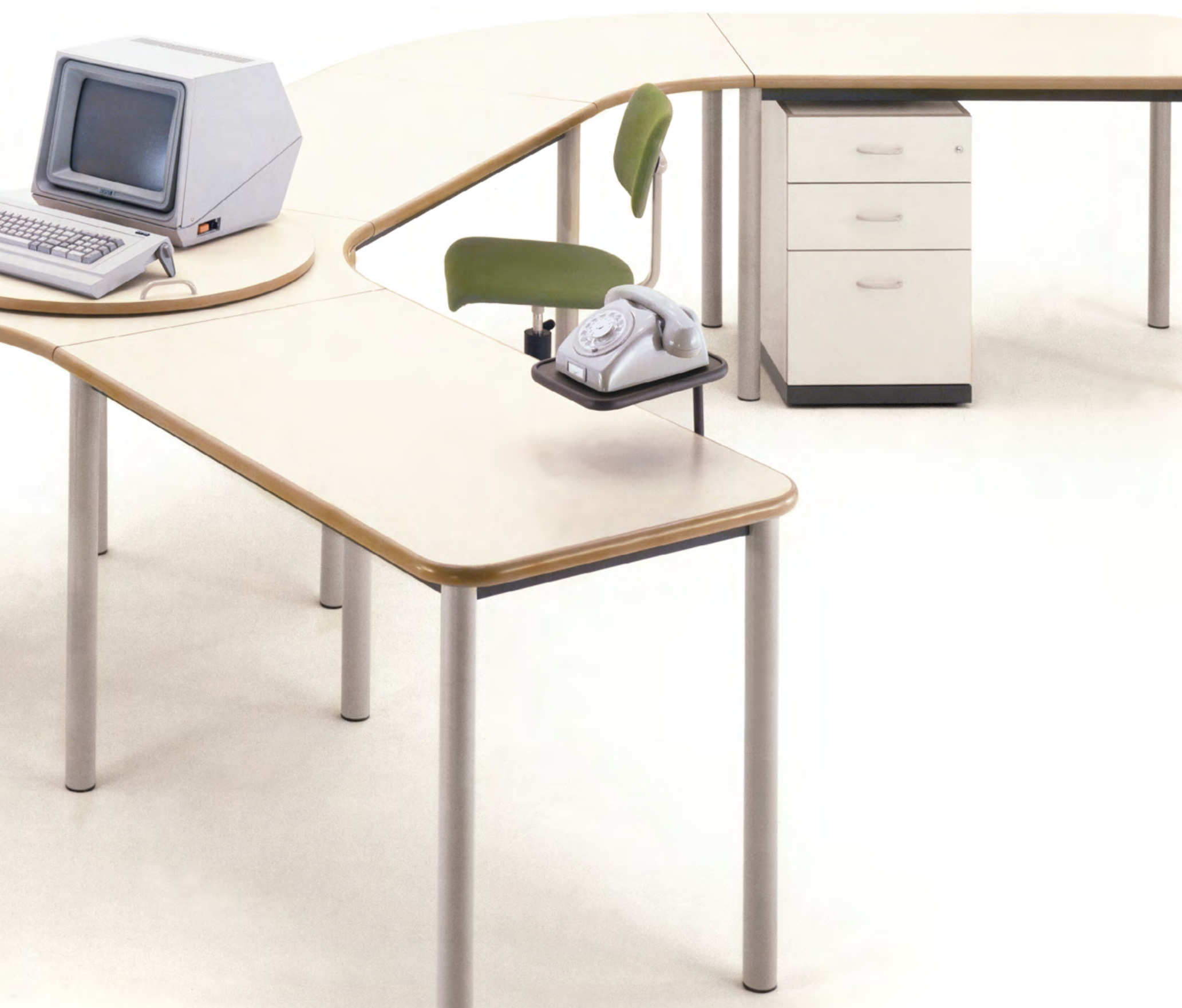


Programa B2 Sistema para bibliotecas

design Bergmiller | JR Calejo

Patente requerida em maio de 1992.

equipe de design da Escriba

Cláudia Moreira Salles 1981-84.

Móveis para biblioteca exigem rigidez estrutural e resistência. Além disso, devem ser observadas normas de segurança e preservação de livros e documentos. Uma biblioteca, a exemplo de um escritório, é também um espaço de trabalho sujeito às constantes evoluções de demanda tecnológica. Integrar essas variáveis em um conjunto de produtos coordenados foi o objetivo do projeto.

Manual para planejamento de bibliotecas, 1984.

Durante o desenvolvimento do programa B2 foram realizados estudos e análises que substanciassem operacionalmente o projeto. Dados sobre guarda e conservação de livros e documentos foram depois reunidos numa publicação técnica para planejamento desses espaços, visando apoiar a atividade dos designers, arquitetos e demais profissionais envolvidos no problema. A idéia de design implantada na Escriba não se limitava apenas ao desenvolvimento dos produtos. Acompanhava-se sua inserção no mercado, inclusive fornecendo ao usuário informação técnica adequada para seu uso.

\section{escriba}

Manual para planejamento de bibliotecas

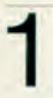

Condiçōes gerais de espaço

Peso

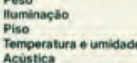

2

Dados sobre áreas de atividades

Acorvo
Fichario

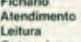

3
4

Quantificação do mobiliário

Proximidade entre areas

Programa B

Estantes
Prateleiras

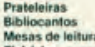

Fichirios
Mapotoca

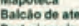

Porta-joenais
Carro para livos

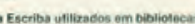

5
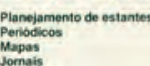

Jomais

Arendimento 


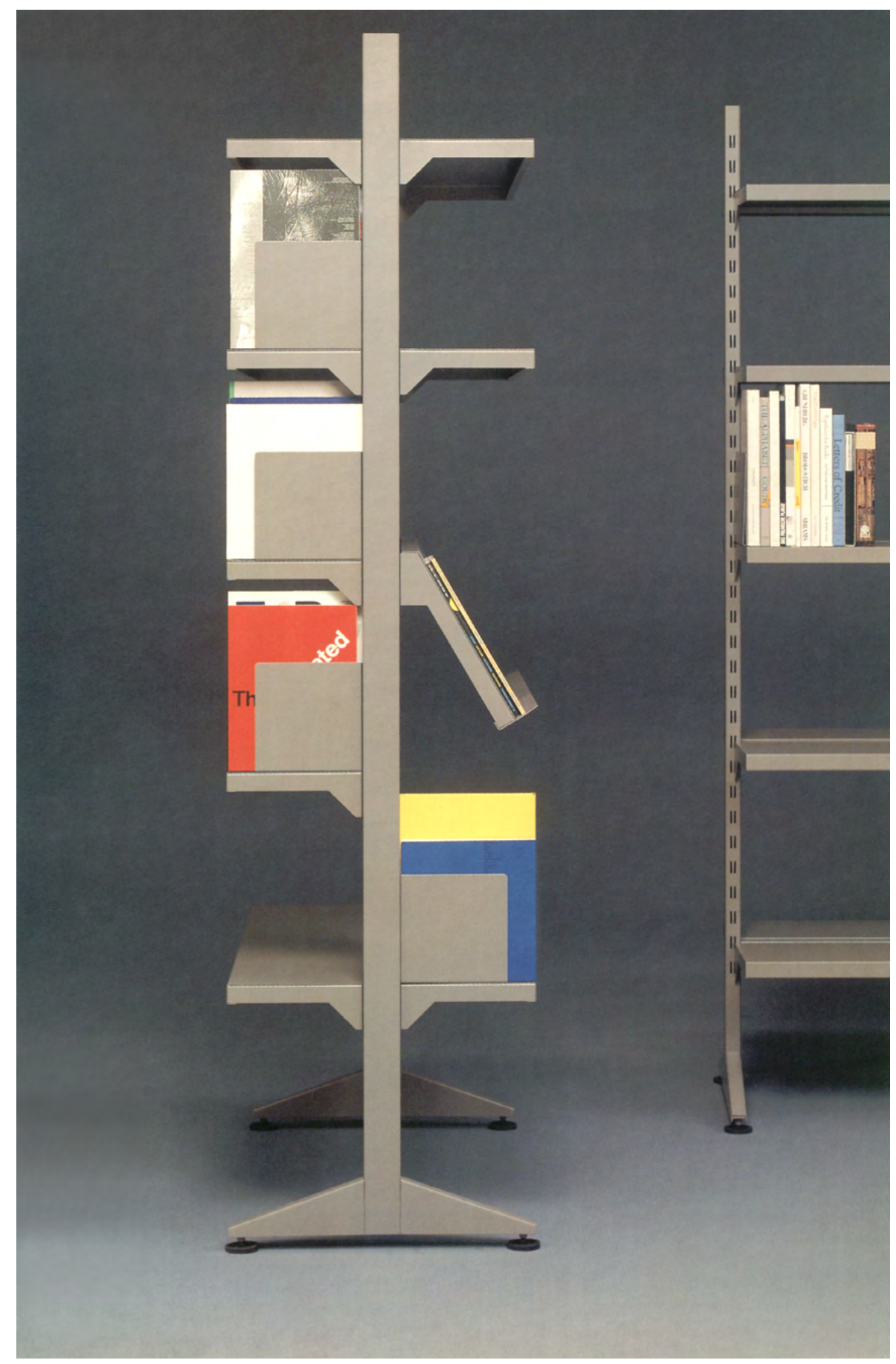

escriba 147 

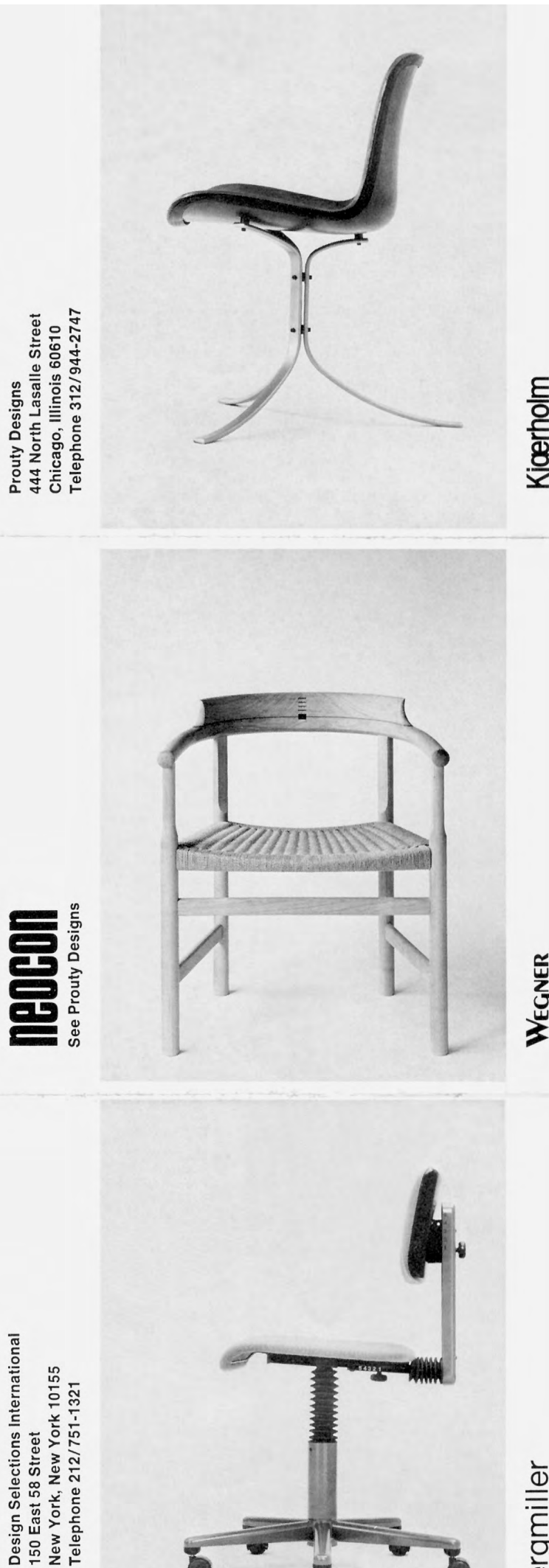

IDSI

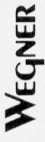

$\frac{\text { 틍 }}{\text { 동 }}$

\section{colaborador José Roberto Calejo Pinto \\ Conforme publicado em catálogo}

A cadeira C2 foi desenvolvida integralmente de acordo com as normas internacionais até porque, na época, não existiam normas nacionais para esse tipo de produto. Na cadeira havia três tipos de ajuste que possibilitavam sua adequação aos mais variados tipos físicos dos usuários: altura do assento, profundidade do assento e altura do encosto, cada uma das regulagens com cinco possibilidades, impressas na própria cadeira.

Catálogo da Design Selections International, NY. Cadeiras dos designers dinamarqueses Hans Wegner e Paul Kjaerholm e a C2 de Bergmi1ler. 


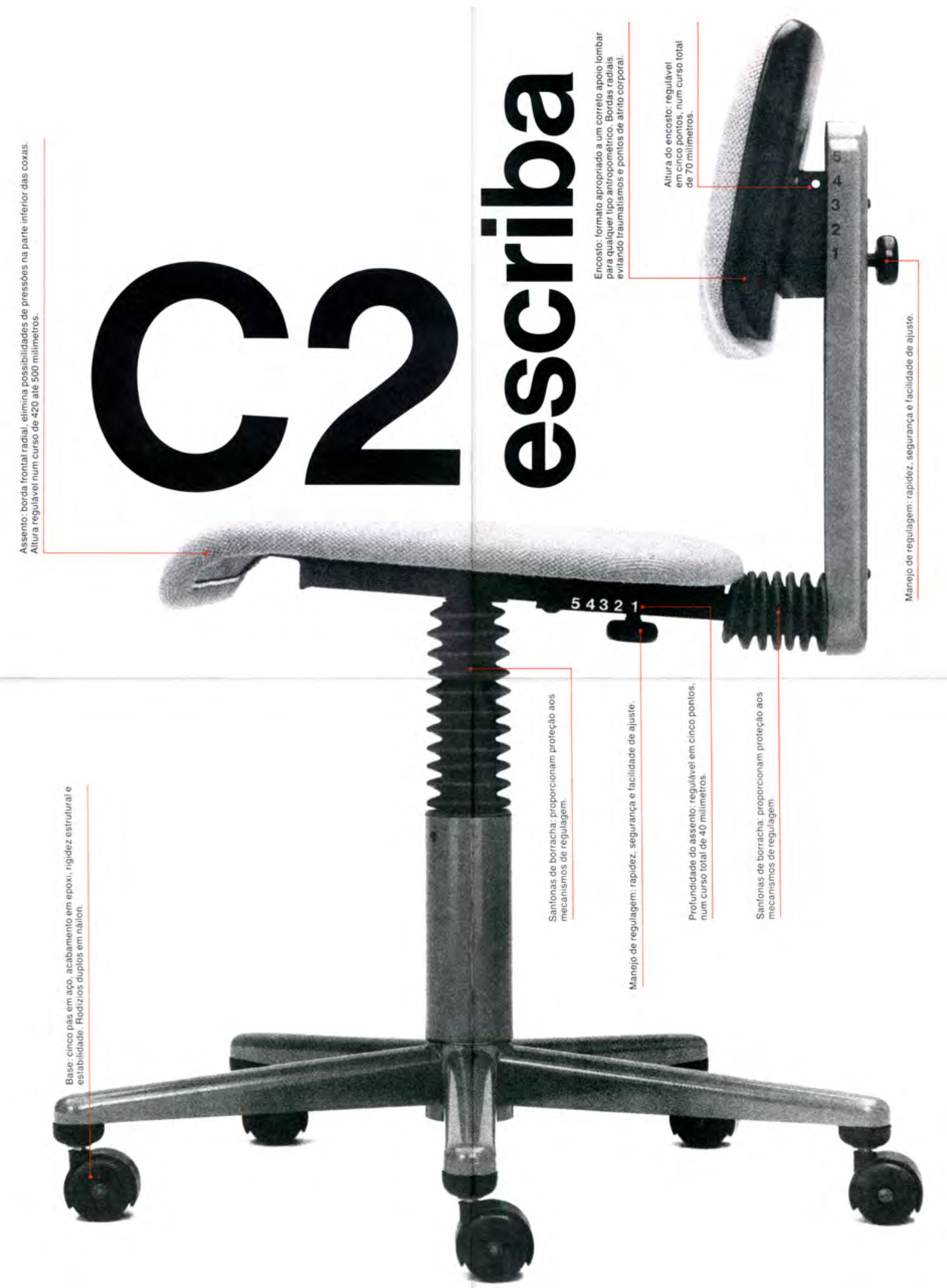

escriba 149 


\section{C3, Cadeira, 1981}

Patente requerida em janeiro de 1992.
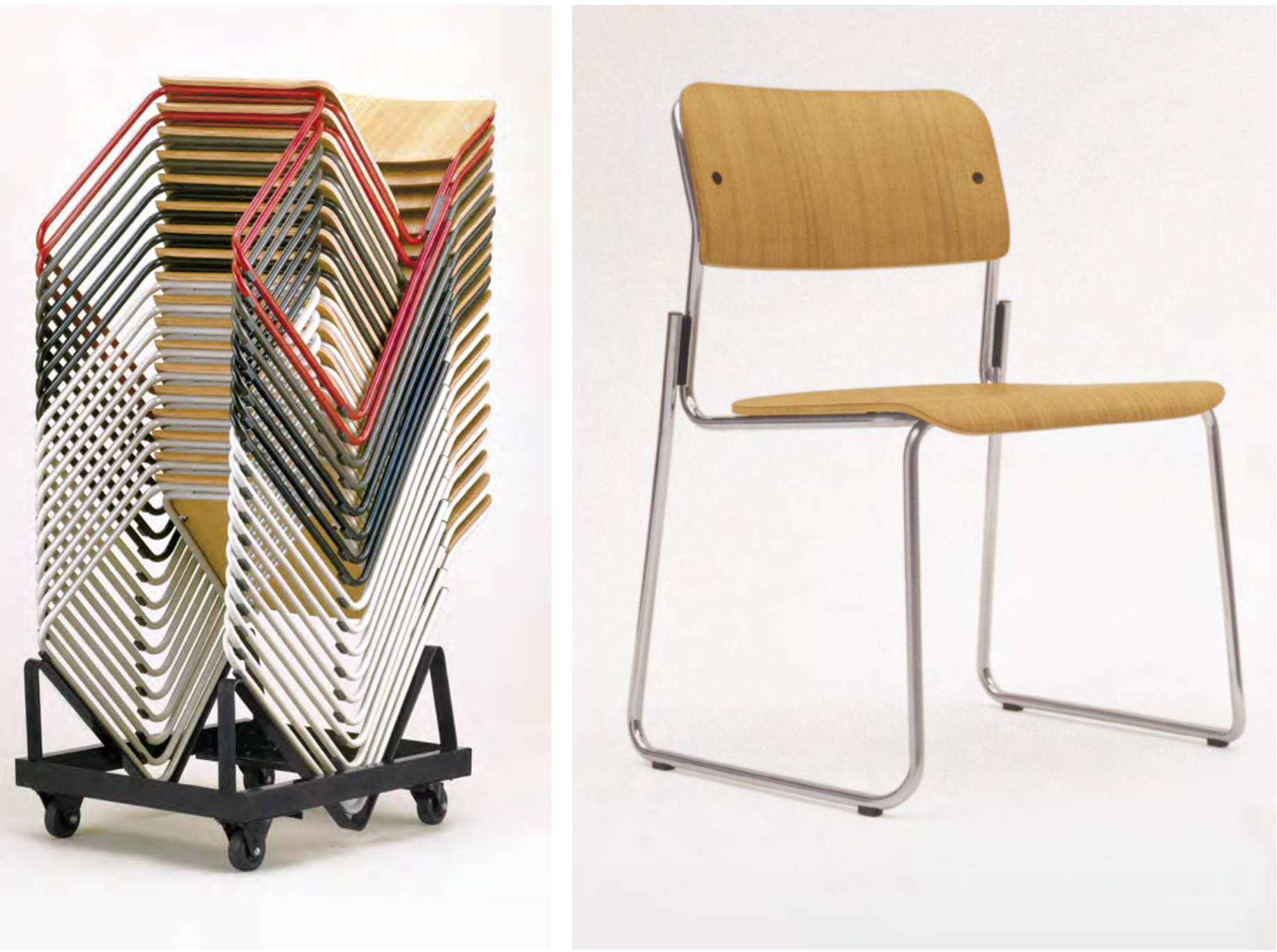

A cadeira C3, de múltiplo uso, foi projetada em diversas versões: assento e encosto em madeira moldada natural, estofada, com braços, com prancheta, com porta-livros, com conectores, montadas em longarinas, possibilitando adaptação a muitas demandas funcionais. Uma simples cadeira que se tornou um sistema. 


\section{C5, Cadeira 1985}

Bergmiller | JR Calejo

Patente requerida, em abril de 1992.

Design gráfico: Alexandre Wollner
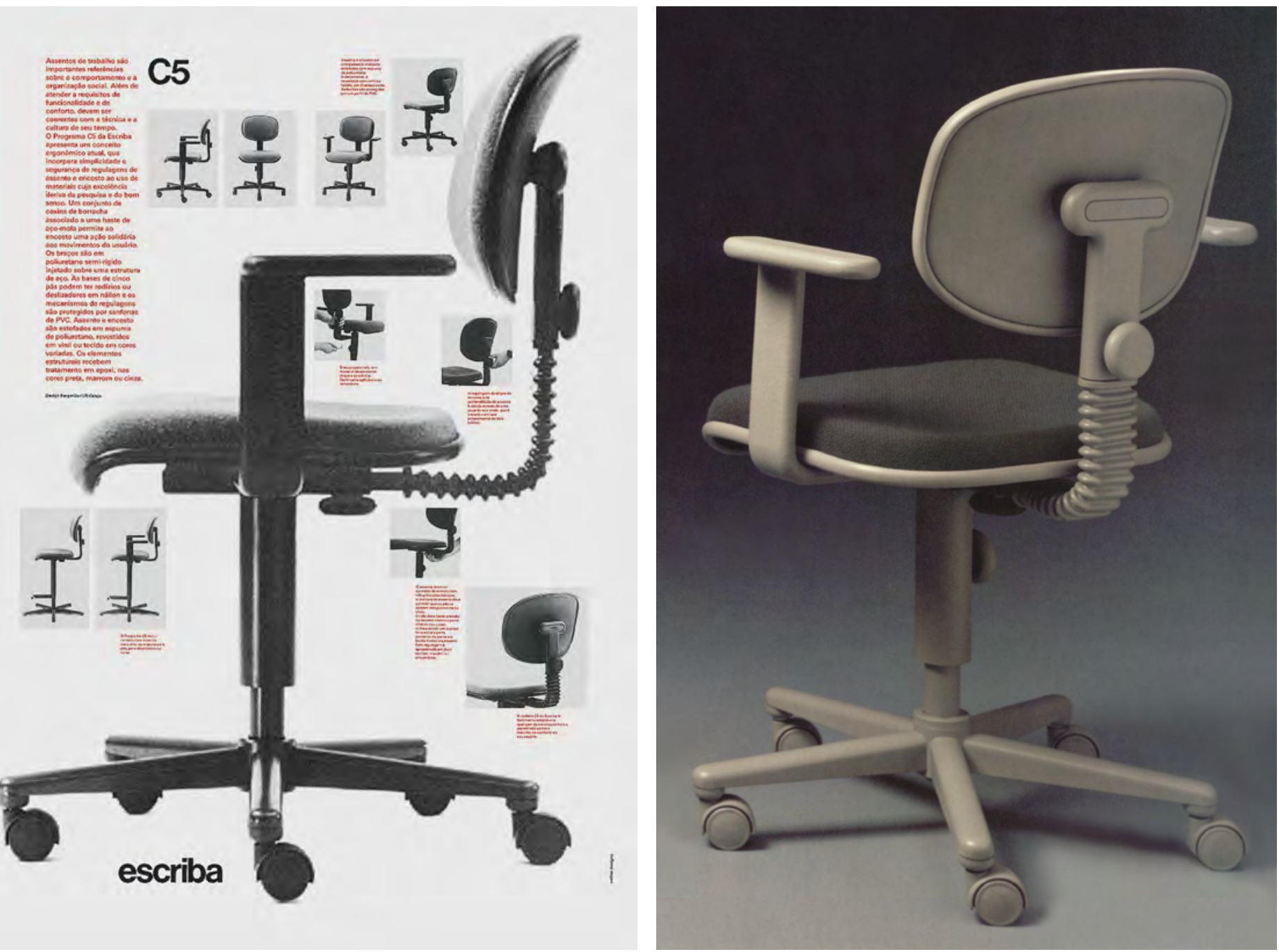

Uma cadeira de trabalho que permitia ajustes básicos e oferecia um conforto adicional por intermédio do molejo aplicado ao encosto. A cadeira tinha um detalhe interessante: braços em poliuretano expandido sobre estrutura metálica que podiam ser encaixados e fixados, com facilidade, pelos próprios usuários. 
Postos de trabalho para equipes criam processos interativos. Admitem o uso de equipamentos comuns e contato permanente. Suas superfícies são ordenadas de acordo com estes princípios.

\section{Chefias são hoje} mais demócráticas nos escritórios. No entanto, ainda se faz necessária uma relativa privacidade.

\author{
As áreas para lazer \\ e espera permitem \\ conforto e integração \\ no trabalho, além \\ de reuniões menos \\ hierarquizadas e \\ formais.
}

\author{
0 posto de trabalho, limitado \\ visualmente por divisórias \\ confere autonomia ao \\ usuário. Inclui elementos \\ auxiliares, assentos reguláveis \\ e prevê a instalação de \\ computadores.
}

Reuniões são necessárias em trabalhos dinâmicos. Locais para reunião fazem parte de um processo participativo.

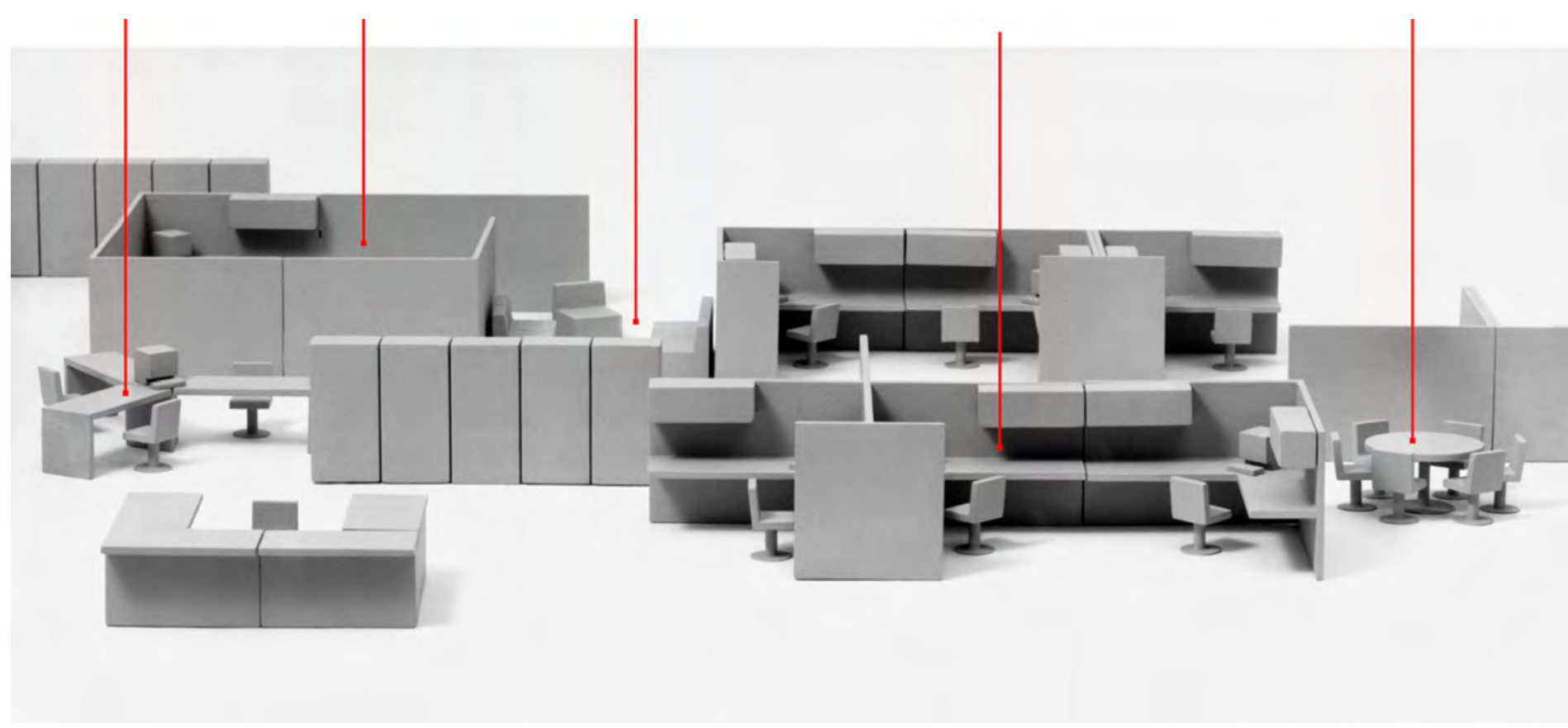

\section{maquete de apresentação}

principais funções desempenhadas em um escritório

- atender, informar, encaminhar - balcões

- concentrar - postos de trabalho individuais, protegidos por painéis

- participar - postos de trabalho abertos, eventualmente acoplados para um trabalho em equipe

- reunir - mesas de reunião

- dirigir, ouvir, discutir, decidir - posto de chefia 
Programa EA - Escritório aberto, 1978

As primeiras idéias relativas a um espaço aberto de trabalho surgiram no início do século XX. Muitos edifícios administrativos foram construídos sem divisões internas, encargo repassado ao futuro ocupante. O desenvolvimento da atividade industrial e o crescimento do setor indireto de administração, planejamento e vendas, conduziram a uma concepção de escritórios semelhantes a fábricas que, em vez de produzir objetos de uso, geravam atividades de controle, na maior parte das vezes traduzidas em papéis.

Uma mudança conceitual importante ocorreu na década de 1950 a partir dos projetos de um escritório alemão, Quickborner Team, que inventou o Buerolandschaft. Esta expressão foi traduzida para open landscape office e assim incorporada a um vocabulário técnico operativo do design e do planejamento de interiores que, no Brasil, foi traduzida para escritório aberto.

O Quickborner Team era formado por um grupo de engenheiros da área de racionalização do trabalho e conseguiu mudar radicalmente o conceito e a aparência dos escritórios. Mas, o mobiliário dos primeiros escritórios planejados nesse conceito nada mais era que as antigas escrivaninhas, armários e assentos. Acrescentaram-se biombos e vasos de plantas, e os novos lay-outs romperam com as geometrias rígidas, aproximando-se mais de uma configuração orgânica.

As empresas avançadas de mobiliário desenvolveram móveis mais adequados a essa configuração e logo perceberam que o conceito de sistema seria o encaminhamento correto para essa nova demanda. Havia facilidade para a formação de postos de trabalho, facilidade de adaptação para diversas atividades e funções nos espaços sem paredes. As vantagens foram sendo percebidas: maior mobilidade, aumento da área útil, facilidades e economia na iluminação e climatização.

O espaço de trabalho tornou-se mais democrático. Porém outros problemas surgiram; muitos deles ligados à acústica dos ambientes, ao piso, aos tetos e paredes que passaram a necessitar de revestimentos e tratamentos especiais. O escritório aberto mudou conceitos, hábitos e costumes, exigiu um novo comportamento, principalmente daqueles que eram acostumados com um trabalho isolado em gabinetes fechados.

As vantagens econômicas e técnicas dos sistemas abertos parecem claras, ainda que não necessariamente para toda e qualquer empresa. Mas todas aquelas que necessitem de rápidas adaptações ditadas por circunstâncias operacionais da eletrônica e da informática poderão se beneficiar de suas qualidades. O sucesso do uso de um sistema aberto está diretamente condicionado à atitude da empresa em relação à ordem de seu próprio trabalho. Não é, portanto, uma questão de moda ou de estilo. Da mesma forma que a informatização é um processo irreversível e progressivo a adoção de um sistema aberto também o é. Aplicado consequentemente esse sistema não admite meios-termos, conciliações ou recuos. Os sistemas abertos deixaram clara a idéia de processo relativa ao design: produtos que estão em permanente aperfeiçoamento e desenvolvimento, que podem conduzir à superação da antiga idéia de projeto em seu sentido mais tradicional. 

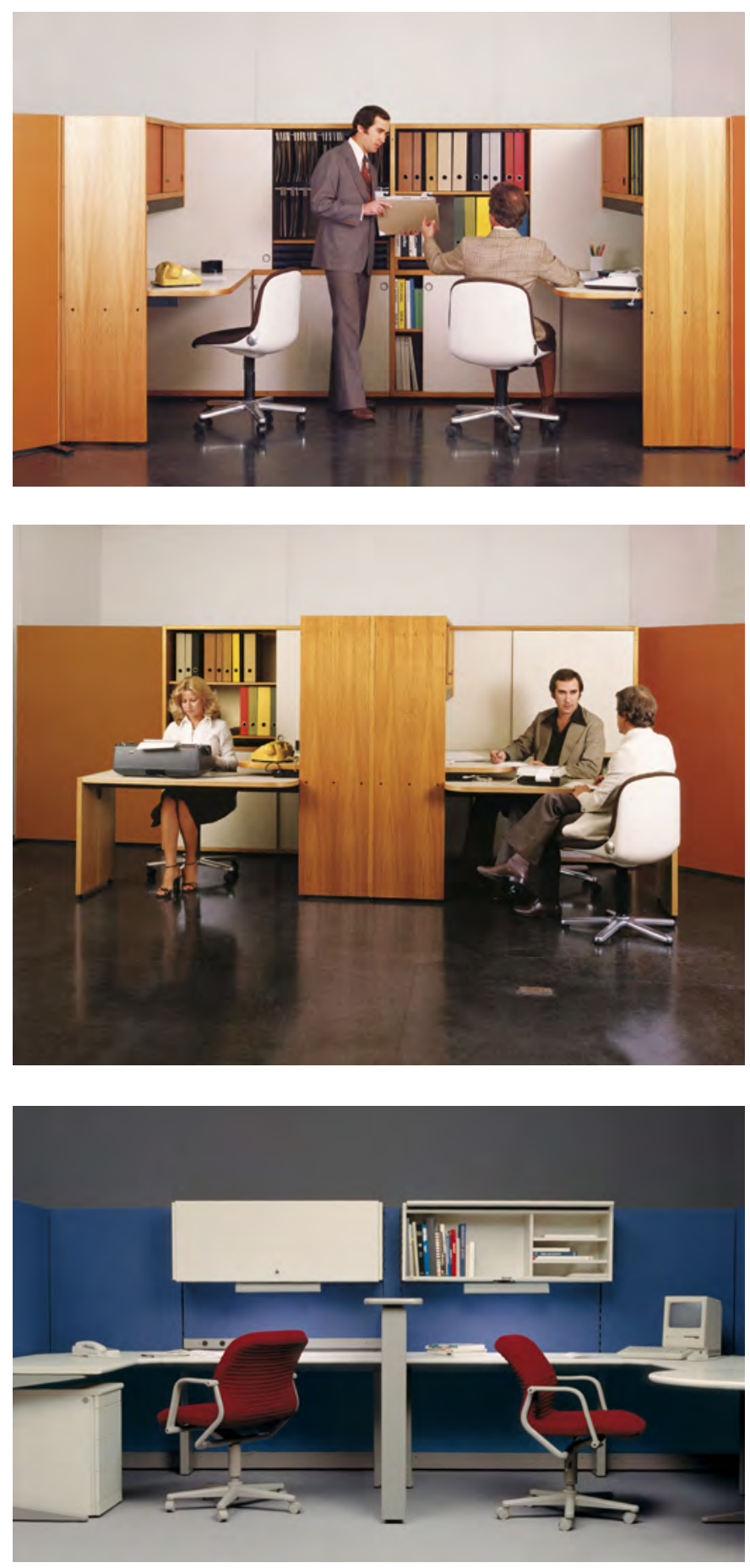

\section{Programa EA1 - Escritório aberto, 1978}

Formação de postos de trabalho em containers, armários com portas de correr com superfícies de trabalho e painéis divisórios acoplados.

\section{Programa EA2 - Escritório aberto, 1987}

Conforme publicado no manual:

superfícies de trabalho (nov. 1989, 2a ed.)

Posto de trabalho do digitador que exige concentração numa postura determinada e rígida, semelhante à datilografia, e que requer especial atenção em aspectos ergonômicos.

\section{Programa EA3 - Escritório aberto, 1990}

Armários suspensos com luminárias, dois postos de trabalho individuais com uma superfície de intercomunicação.

\section{Programa EA4 - Escritório aberto, 1996}

Conforme publicado em catálogo

Design gráfico: Christine Miocque

Puppin Fotógrafos

O programa EA4 atende à preponderância dos meios informatizados no escritório contemporâneo. A instalação fácil e segura dos cabos e fios passou a ser uma exigência técnica básica. Sabemos que as novas tecnologias sem fio poderão trazer novos conceitos, eventualmente mais simples, gerando novas versões de mobiliário para essa área. 

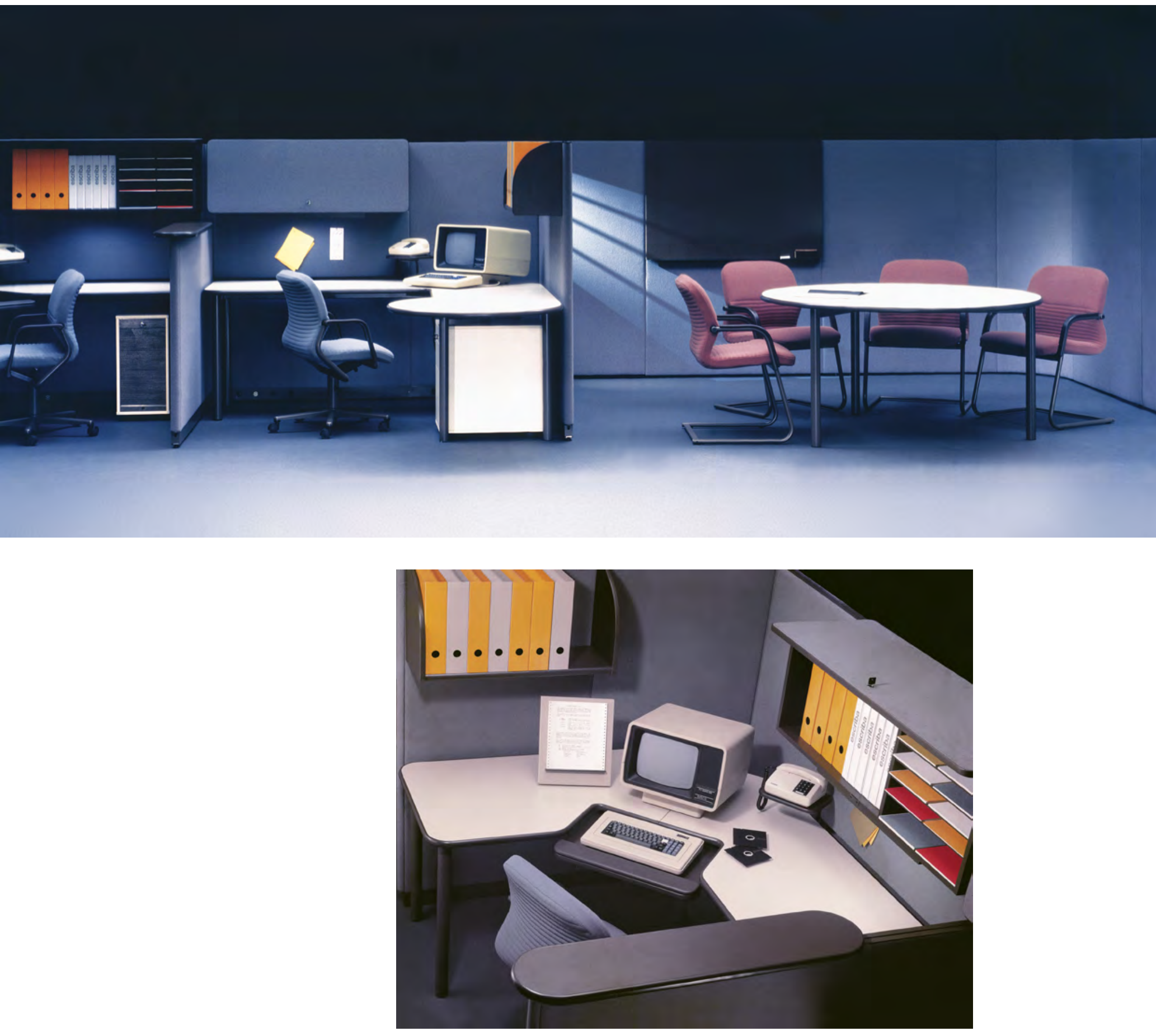


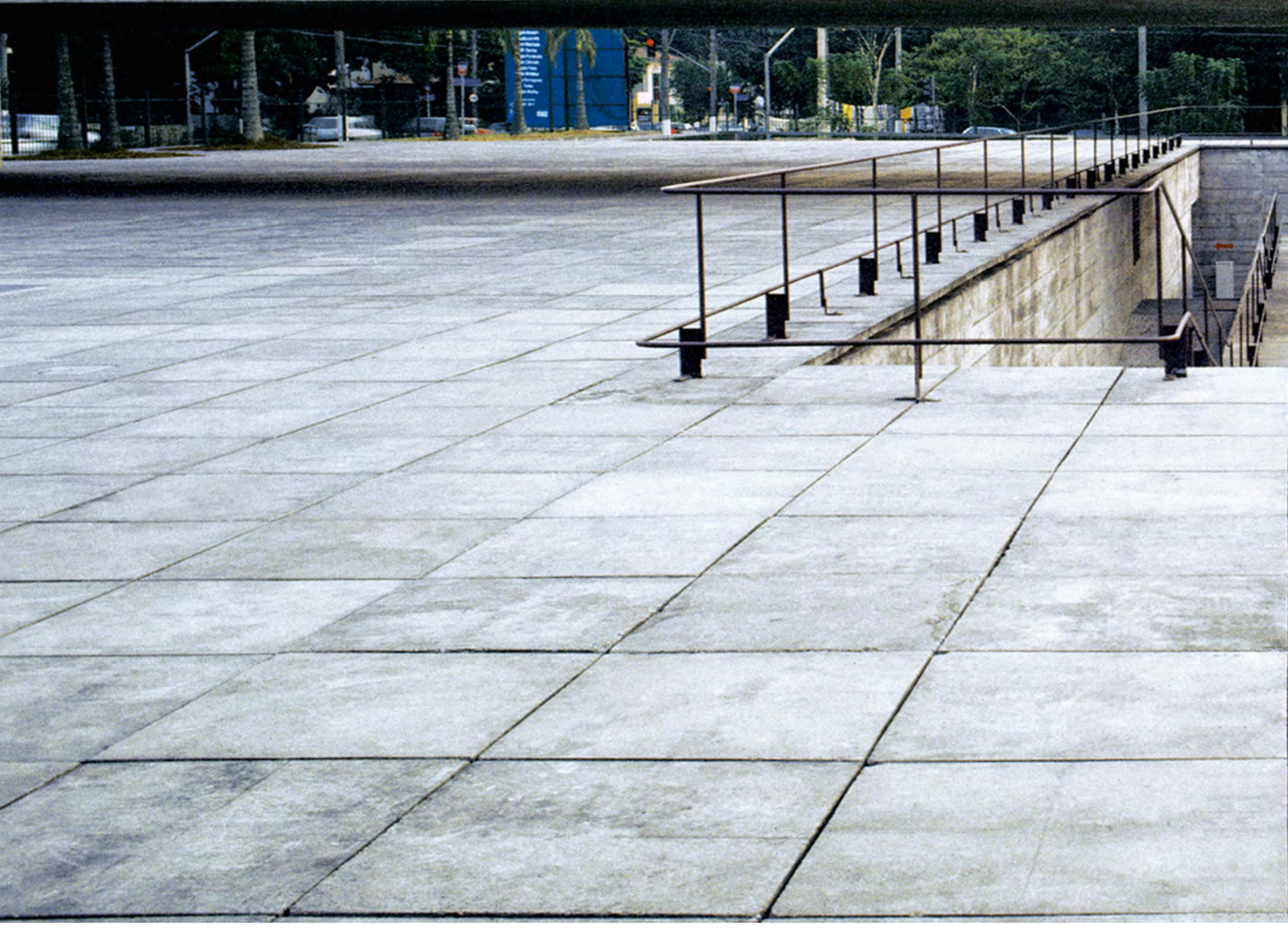


EA4 a quarta geração do Escritório Aberto

MuBE - Museu Brasileiro da Escultura, São Paulo, 1996.

Lançamento do programa de móveis de escritório

para espaços abertos.
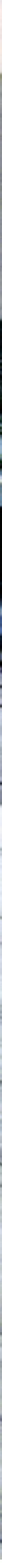

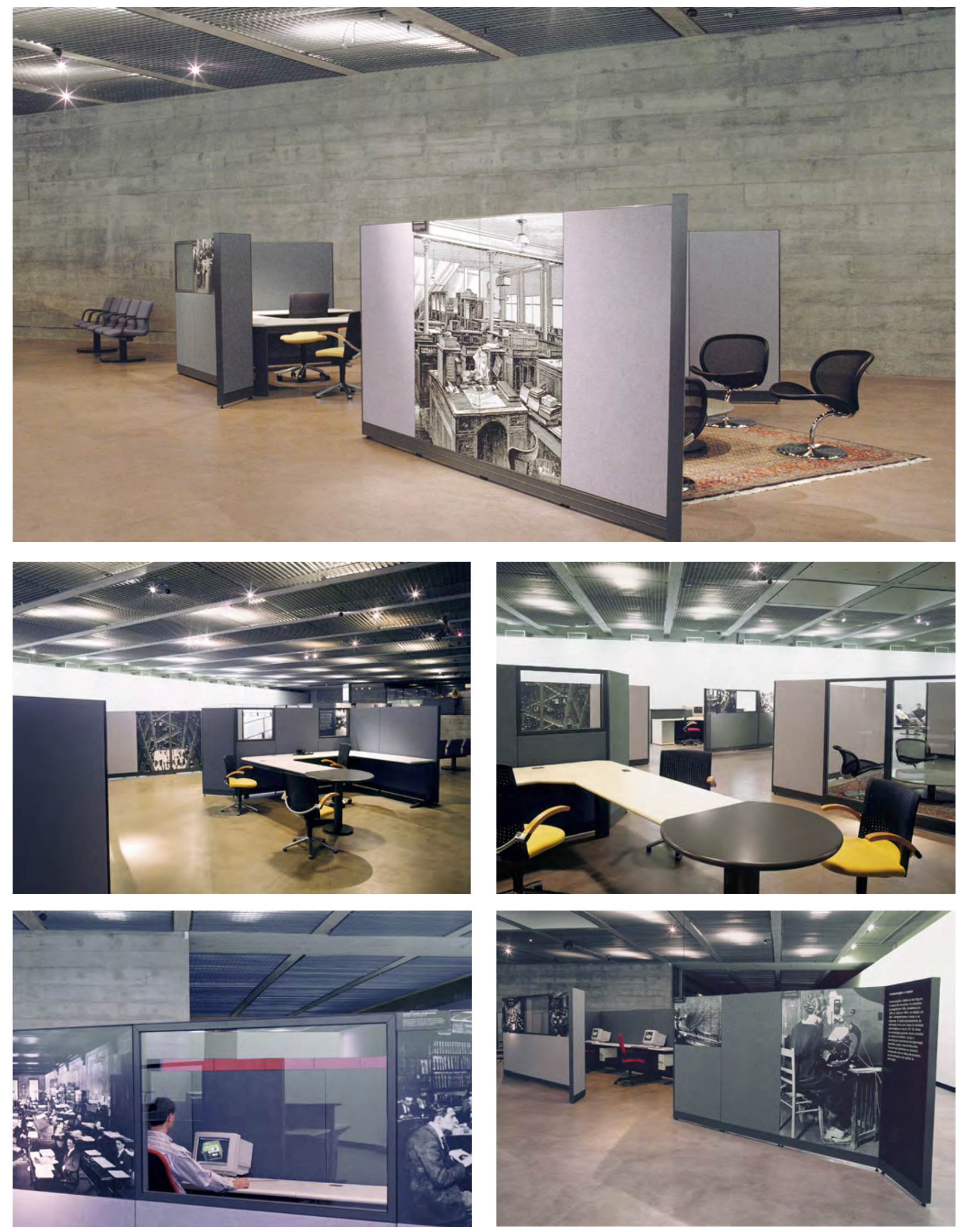
Lançar um novo produto em um espaço cultural conduz a algumas indagações: Uma exposição de design pode ser considerada um evento cultural? Ocupar um espaço dessa natureza confere algum tipo de prestígio ao produto?

EA4 era a quarta geração do programa de móveis de escritório para espaços abertos da Escriba. Seu lançamento foi realizado no MuBE, uma das mais belas obras do arquiteto Paulo Mendes da Rocha. A mostra não se limitou à apresentação de uma extensa e complexa linha de produtos.

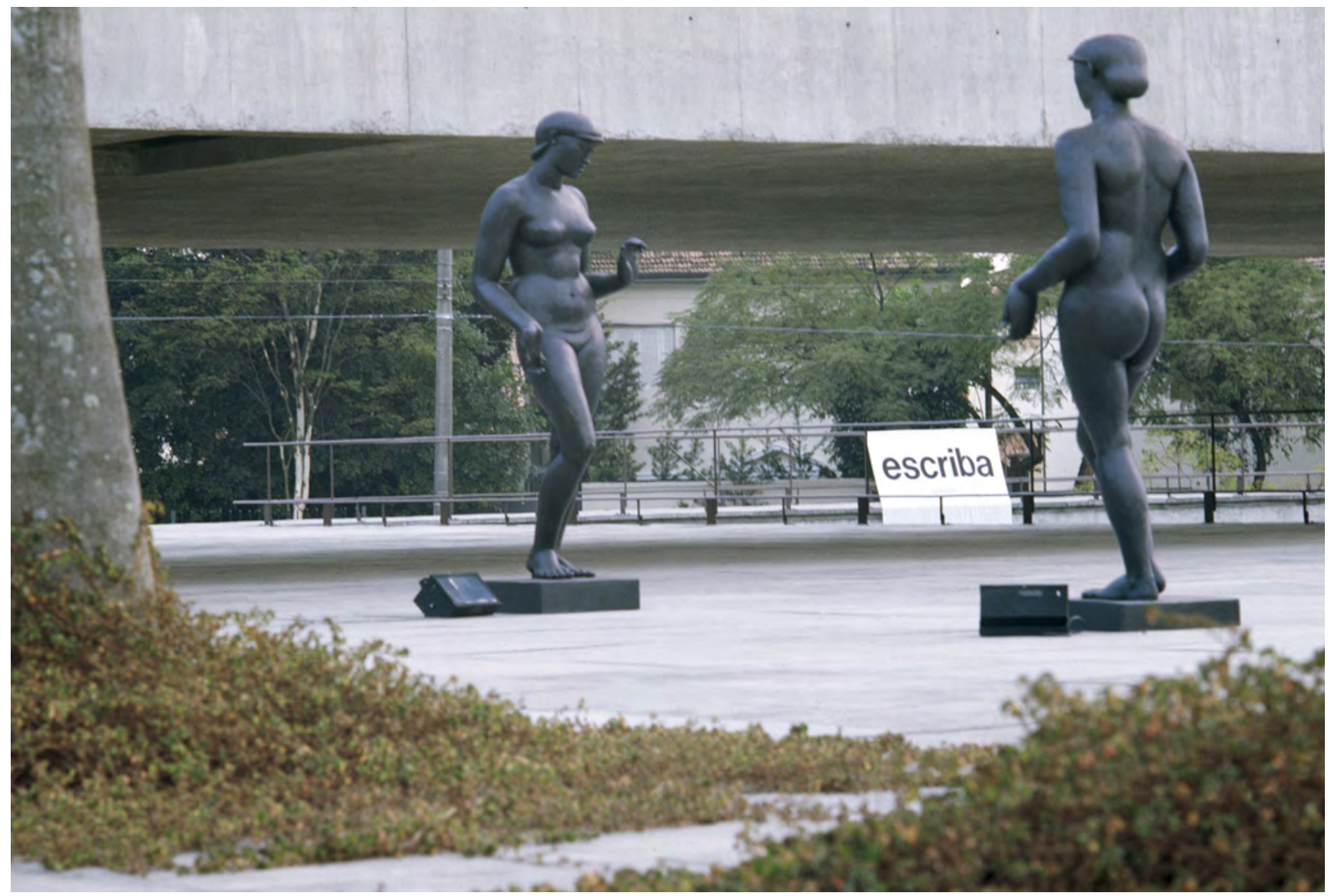

Procurou-se propor algo original e compativel com o espaço onde foi implantada. Foi dada ênfase em informações que ultrapassavam os meros elementos descritivos do mobiliário.

Nessa fusão de informações foi apresentada a evolução do escritório em espaços abertos de trabalho, através de painéis fotográficos de exemplos significativos tanto de origem brasileira como do exterior. O próprio sistema construtivo do EA4 serviu como suporte físico para os painéis. A identificação do evento fora e dentro do MuBE foi também coerente com a natureza do espaço, sem uma presença ostesivamente comercial, respeitando a obra arquitetônica. 


\section{Forma e função no final do século XX, 1987}

Exposição inaugurada em 20 de outubro.

Rio de Janeiro, Salão Carlos Drumond de Andrade,

Palácio da Cultura Gustavo Capanema.

Planejamento:

Karl Heinz Bergmiller,

Goebel Weyne,

Pedro Luiz Pereira de Souza

e Bitiz Afflalo.

\section{Colaboradores :}

José Roberto Calejo,

Francelízio Barra,

Carlos Alberto A. Silva Jr., Ricardo Luiz Gonçalves Dias e Heitor Delgado.
Como parte das comemorações de 25 anos de trabalho da Escriba foi realizada uma exposição e alguns eventos de caráter cultural. Ao invés de planejar uma campanha publicitária convencional a empresa optou por realizar um concurso sobre: "como seriam os escritórios em 2012", ou seja, nos 25 anos seguintes.

Esta foi uma política implantada na empresa a partir do design: assumir compromissos com o usuário não apenas com produtos de qualidade, mas também com o discurso promocional e sua imagem pública. A Escriba preferiu uma linguagem mais informativa e menos persuasiva. Os mesmo critérios qualitativos que procurava em seus produtos estavam presentes em sua imagem visual, em sua arquitetura, na preocupação com o meio ambiente, seu pessoal e a segurança no trabalho.

A Escriba entendeu que havia a necessidade de uma evolução nas relações entre projeto, produto e sociedade e que são essas relações, além da tecnologia, dos processos de fabricação e da organização interna, que explicam as mudanças que ocorrem nos produtos. Exposições e manuais de orientação de usuário não eram apenas elementos promocionais.

Essas mudanças decorrem da certeza de que a técnica não é uma finalidade em si, isolada de um compromisso social amplo, representado pela produção de bens materiais. A publicidade da Escriba procurou sempre falar para o usuário através de uma linguagem acessível, que o conduzisse a um mínimo de reflexão sobre esses conceitos básicos.
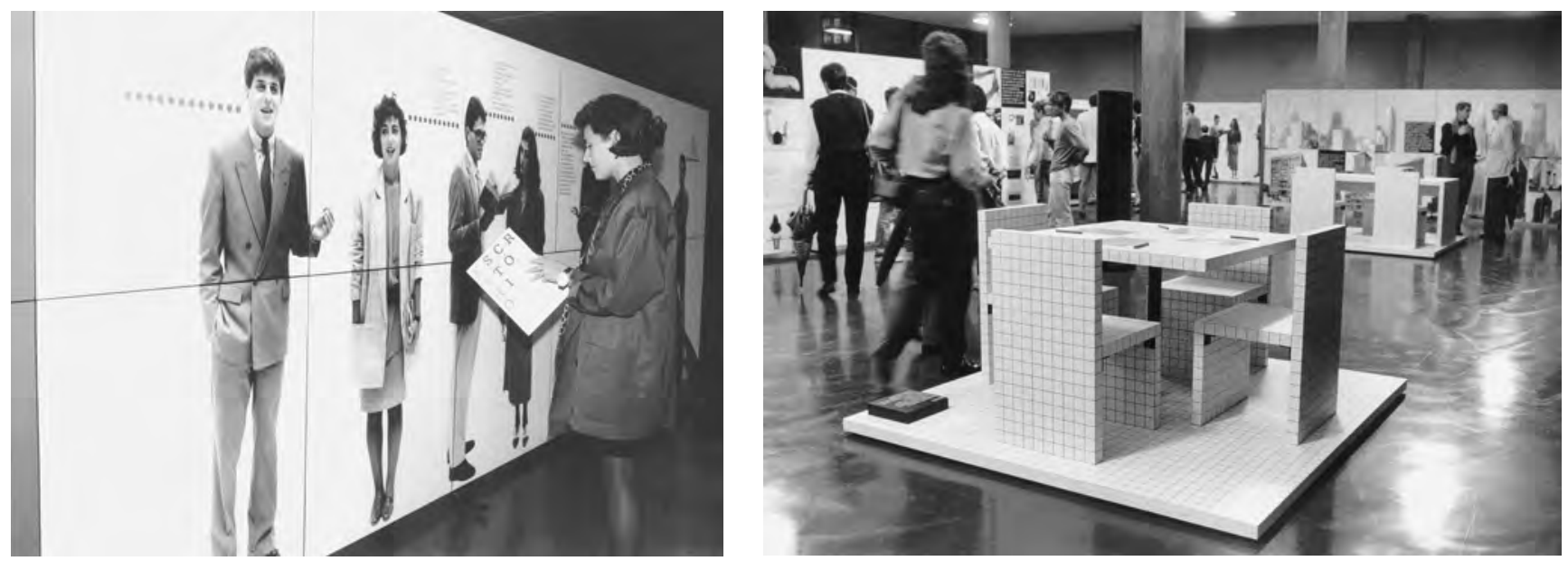
São Paulo, Museu da Casa Brasileira.

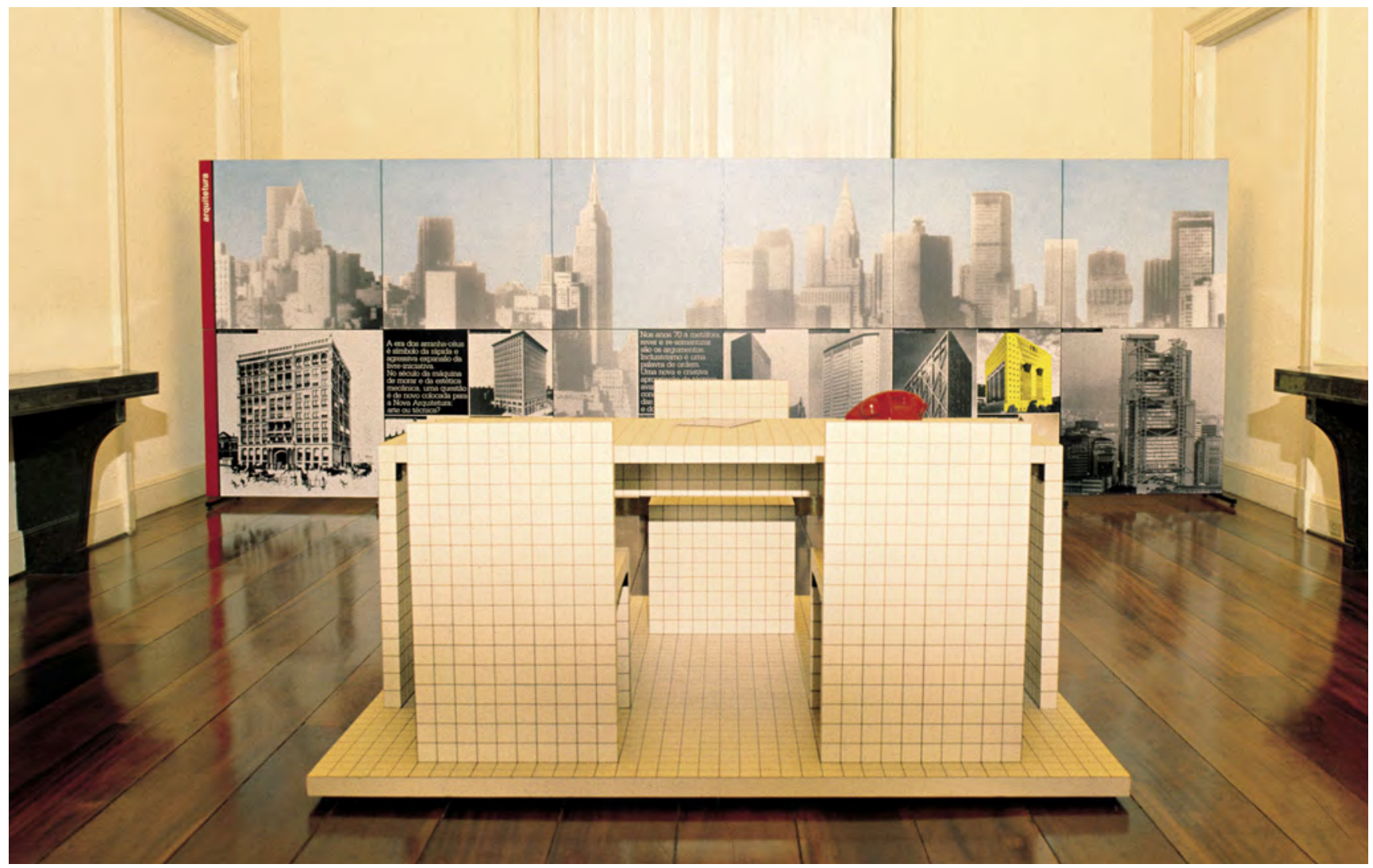

Belo Horizonte, Palácio das Artes.
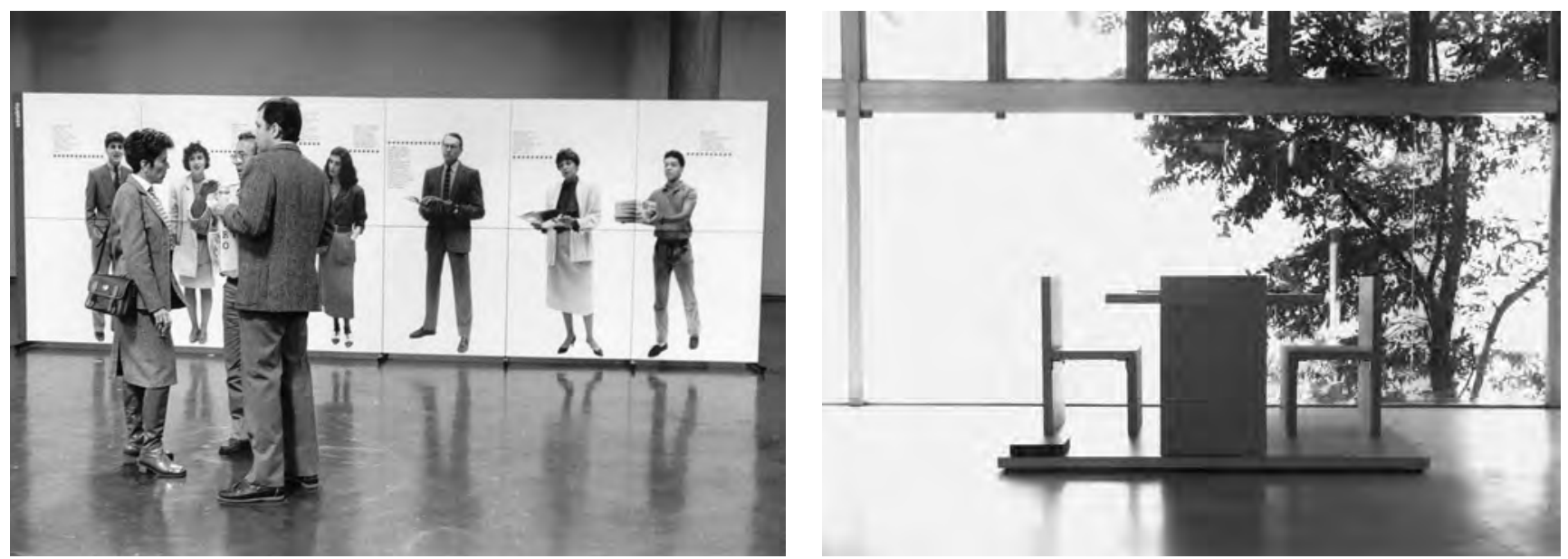

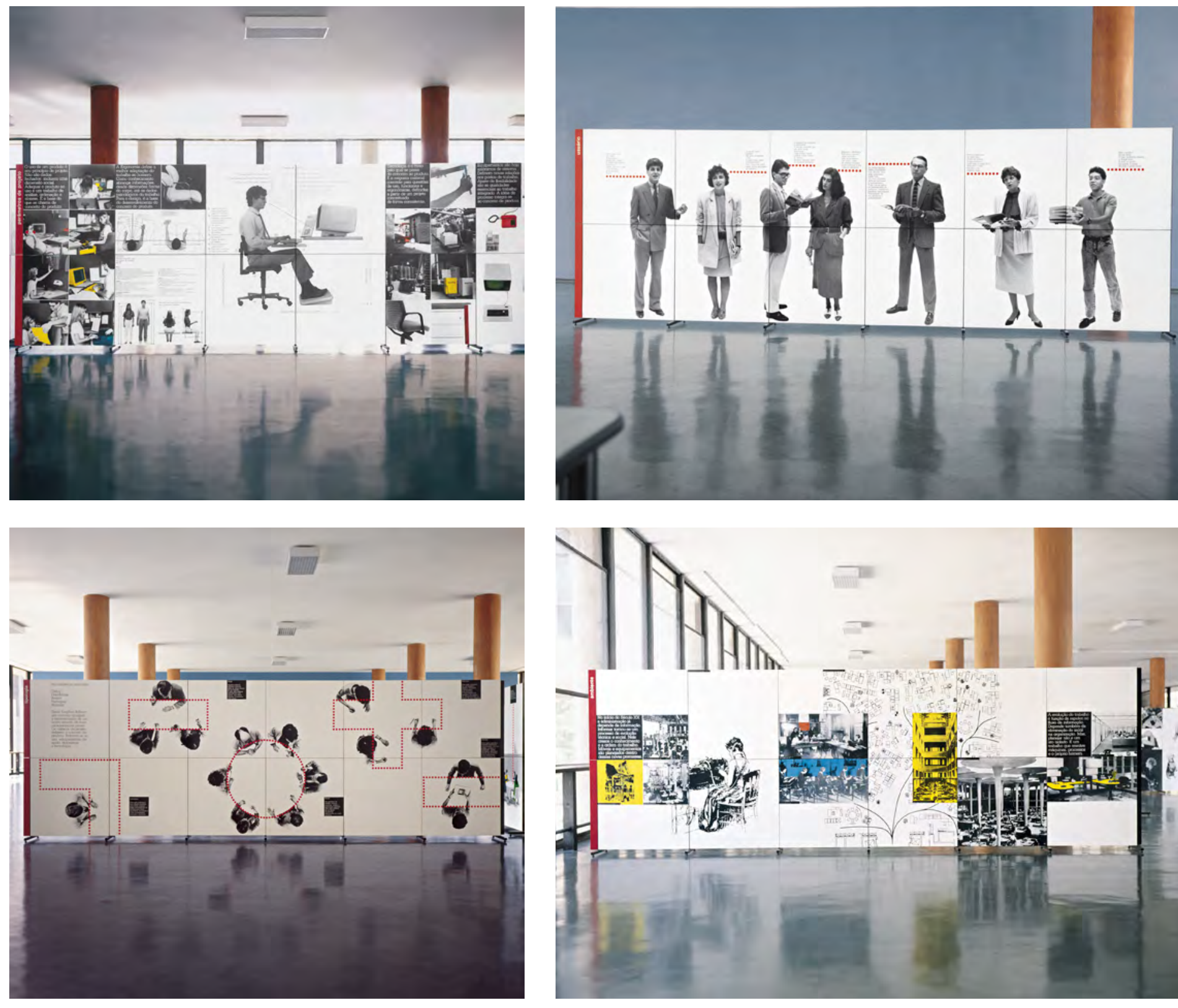
Forma e função no final do século XX, 1987

Palácio da Cultura Gustavo Capanema

Rio de Janeiro

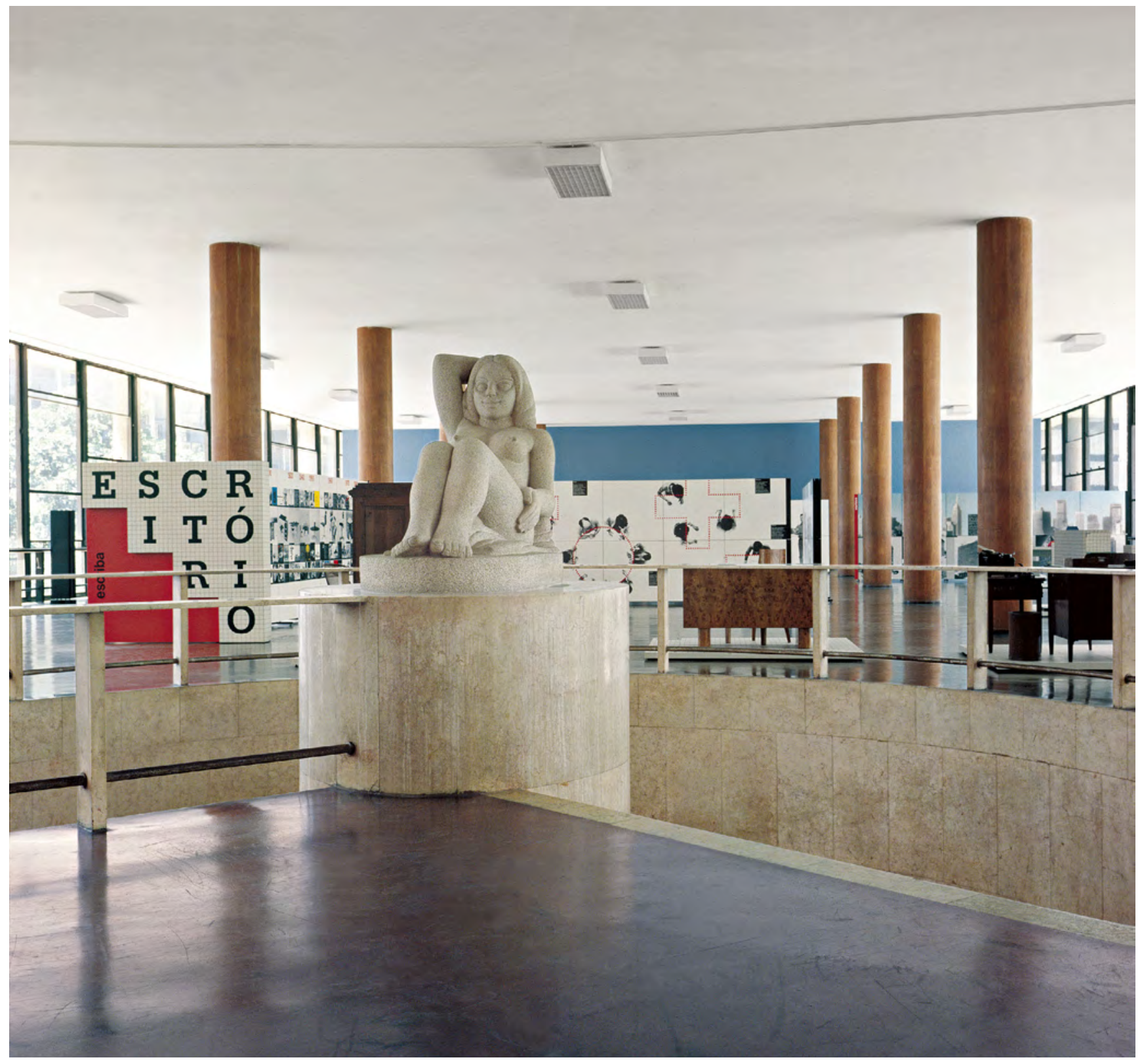




\section{Programa S 200}

Sofá com laterais em poliuretano semi-rígido

injetado com estrutura de aço.

\section{Programa S 400}

Sofá com laterais em painéis estofados.

Nos escritórios os sofás são usados em gabinetes ou antesalas executivas. Ambientes dessa natureza não comportam um tipo de móvel com características domésticas ou muito informais. Normalmente são móveis utilizados por períodos curtos de tempo mas, ainda assim, devem oferecer conforto e evitar posturas inadequadas. Nos três programas apresentados, os componentes básicos - assento, encosto e almofadas - são os mesmos. A diferença entre eles está no acabamento. Todas as versões, de um, dois ou três lugares, apresentam as mesmas qualidades técnicas e funcionais e da mesma forma que nas mesas de trabalho, a idéia de racionalização fica evidente.

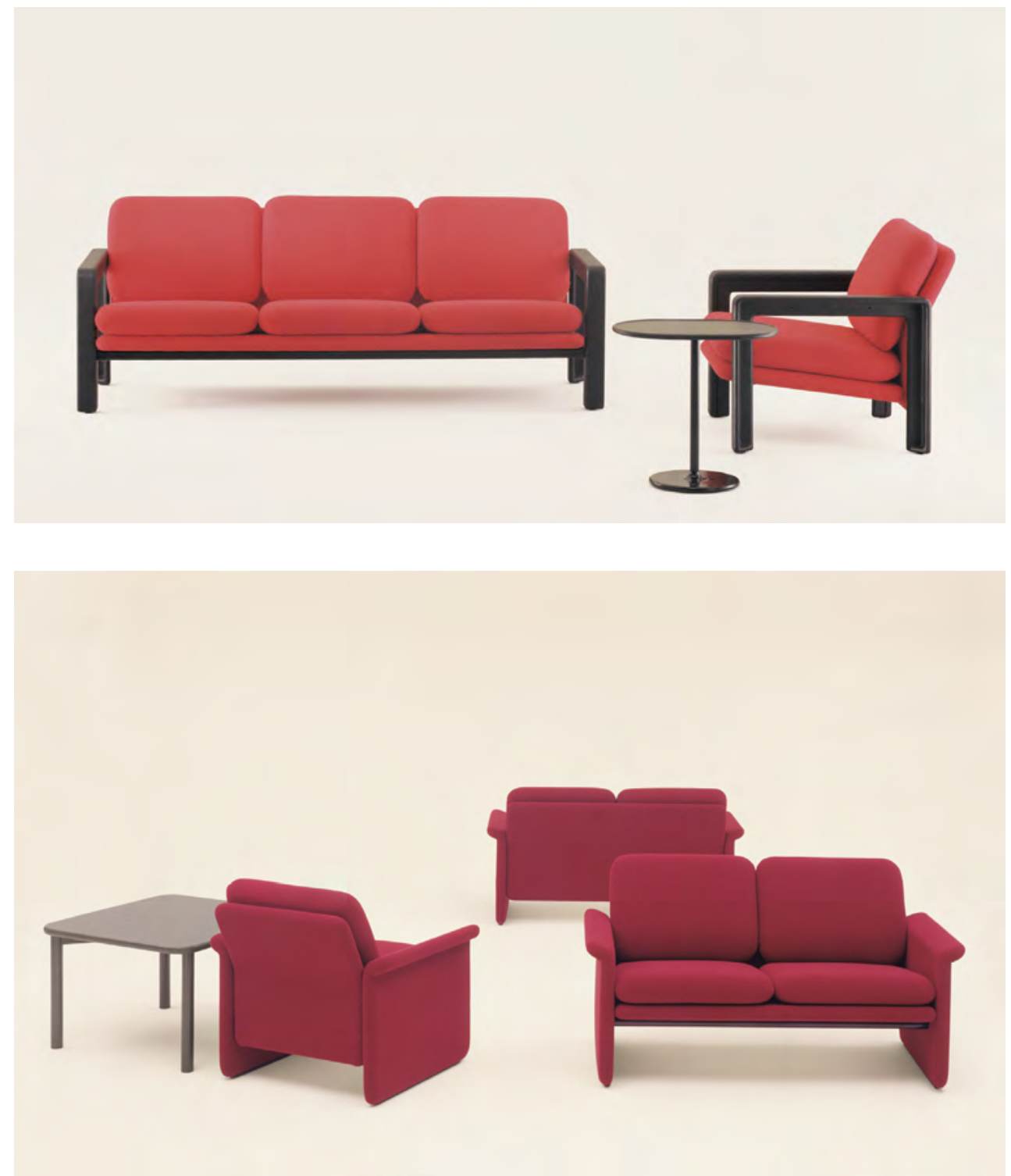


Programas de sofás, 1997

Bergmiller | JR Calejo

Conforme publicado em catálogo

Design gráfico: Christine Miocque

Puppin Fotógrafos

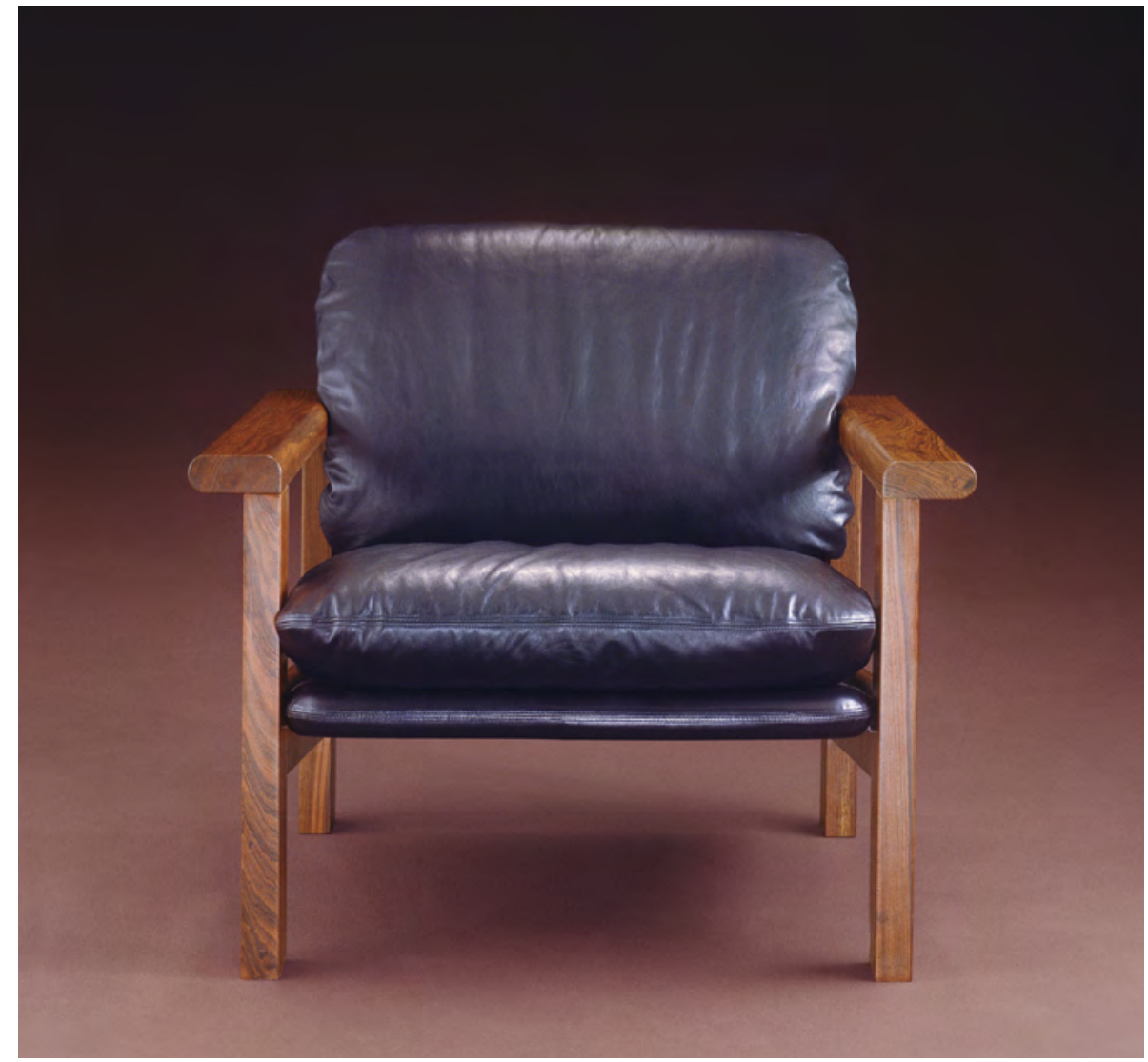

Sofá com laterais em madeira maciça.

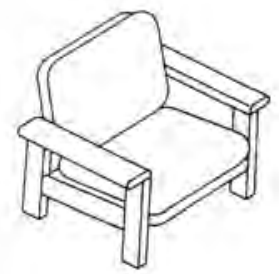

um lugar

one seat

S301

$178 \times \mathrm{P} 87 \times \mathrm{H7} 6 \mathrm{~cm}$ W31 $\times 134 \times 1430^{\prime \prime}$

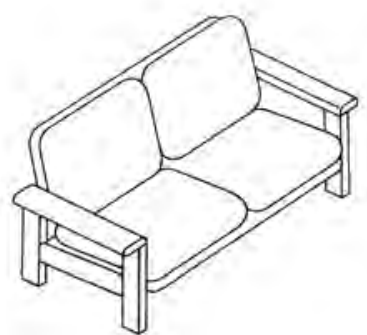

dois lugares two seats

\section{S302}

$\mathrm{L} 140 \times \mathrm{P} 87 \times \mathrm{H} 76 \mathrm{~cm}$ W55 × $034 \times \mathrm{H}^{3} \mathrm{O}^{\prime \prime}$

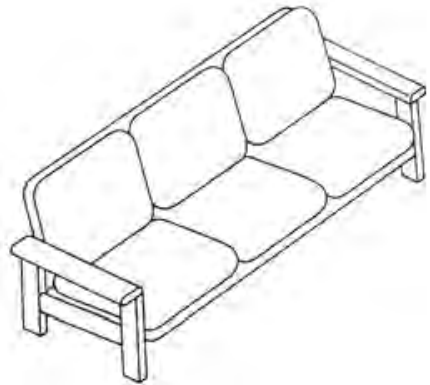

trés lugares three seats

S303

$\mathrm{L} 202 \times \mathrm{P} 87 \times \mathrm{H} 76 \mathrm{~cm}$ W79 $\times$ D $34 \times \mathrm{H}^{\prime \prime \prime}$ 


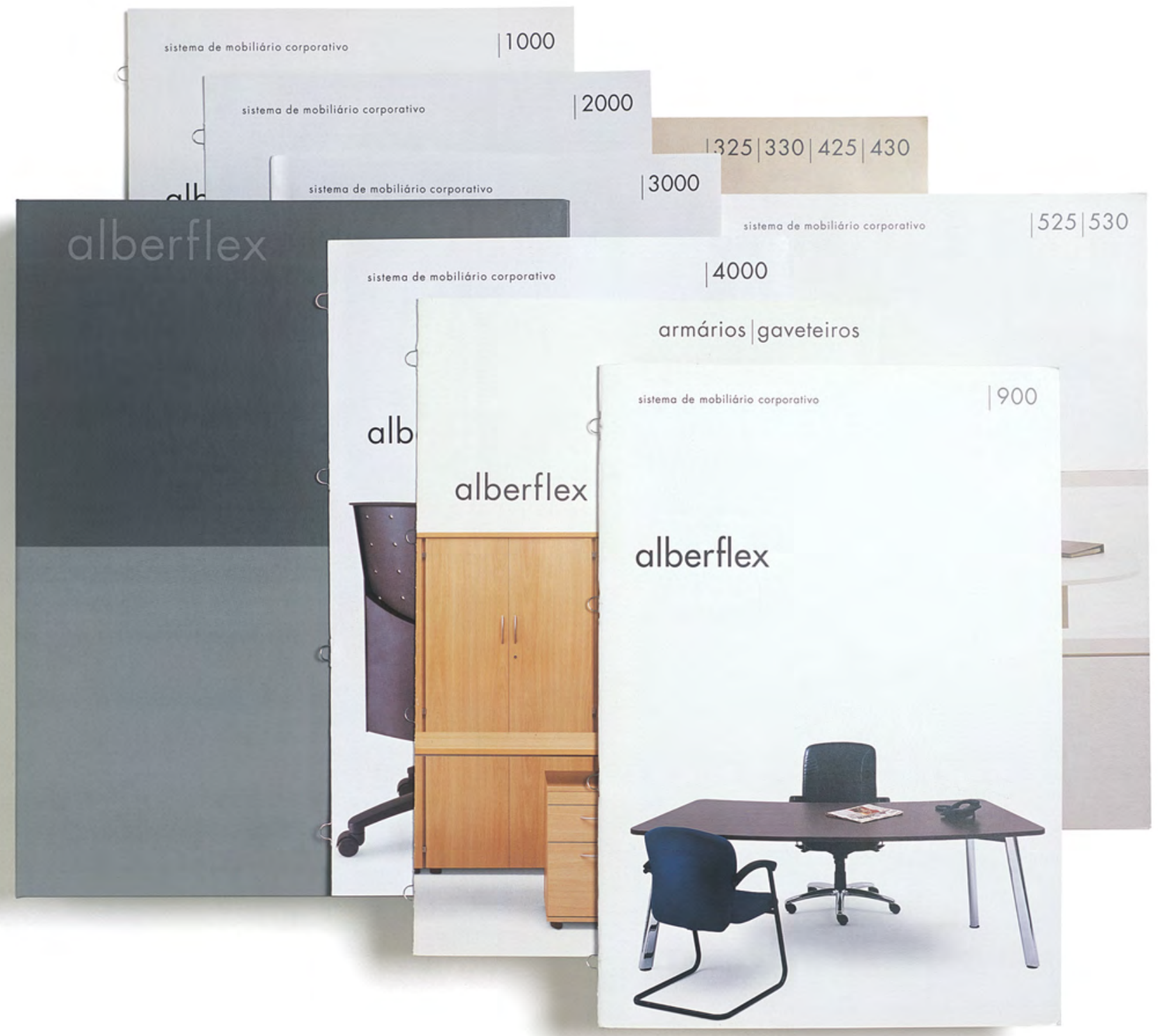




\section{a Alberflex}

A Alberflex era, na década de 1970, a maior indústria brasileira de mobiliário escolar, época em que o IDI/MAM, Instituto de Desenho Industrial do Museu de Arte Moderna do Rio de Janeiro, desenvolveu uma pesquisa para o Ministério da Educação, Companhia Brasileira de Construções Escolares, MEC/ CEBRACE, para estabelecer padrões e critérios técnicos, construtivos e ergonômicos, para esse tipo de produto. $\mathrm{O}$ apoio da Alberflex foi decisivo para o sucesso dos trabalhos, pois todos os modelos de teste e protótipos foram executados pela empresa, chegando a conclusões objetivas e concretas, circunstâncias, até então, muito raras no país. A Alberflex fabricou esse tipo de mobiliário durante muitos anos, seguindo fielmente as recomendações formuladas com sua colaboração. Estabeleceram-se durante o desenvolvimento da pesquisa vínculos de colaboração técnica, de cordialidade e de respeito mútuos.

Mas, alguns anos depois, a empresa abandonou esse setor, passando a se dedicar exclusivamente à fabricação de mobiliário para escritório. As características de mercado e os critérios qualitativos entre um e outro setor são bastante diferentes, pois o mobiliário escolar destina-se principalmente ao ensino público, tendo como maior cliente as secretarias de educação pública, instituições oficiais cujos critérios prioritários de licitação concentram-se normalmente no preço baixo, por vezes flexibilizando excessivamente as recomendações de qualificação técnica, de ergonomia e os requisitos pedagógicos. Mesmo depois de elaboradas pelo IDI e publicadas pelo MEC/CEBRACE, nem sempre as recomendações foram devidamente seguidas. Além disso, nessas concorrências públicas, sempre estiveram presentes velhos hábitos e costumes, vícios, ignorâncias e esquemas de influências que infelizmente caracterizam grande parte desses processos no país. A Alberflex, comprometida com sua qualidade anterior e reforçada pelo compromisso assumido com as recomendações do IDI/MAM, sentiu-se desiludida e frustrada com esse panorama e abandonou a fabricação de móveis escolares, passando a operar apenas no segmento do mobiliário para escritório.

Nesse setor, o principal cliente é a empresa privada, pelo menos desde o final do chamado milagre brasileiro, época em que as empresas estatais se constituíam em seus maiores demandantes. Os critérios de licitação, no caso das empresas privadas, são relativamente diferentes daqueles observados no setor público e, por isso, as empresas nele inseridas investiram em tecnologia e aprimoramento de processos de fabricação, adaptaram seus produtos à evolução 
dos meios de comunicação e da informática e compreenderam muito bem a necessidade de respeitar as recomendações ergonômicas, acompanhando a evolução dos padrões internacionais mais que qualquer outro setor da indústria moveleira. O setor de mobiliário para escritório sempre foi um campo de trabalho muito receptivo para os designers brasileiros, especialmente para aqueles habituados a trabalhar com critérios funcionalistas.

A Alberflex desenvolveu uma competência técnica muito grande e, como decorrência, uma posição bastante confortável no mercado. Mas, compreendeu também que seus produtos inseriam-se num processo contínuo de aprimoramento e que chegar a bons resultados era mais que um objetivo medido por critérios fixos e préestabelecidos. Diante da excepcional evolução dos meios de comunicação, uma empresa desse setor deve estar apta a evoluir o tempo todo e assim, seus produtos também devem corresponder a essas prerrogativas. Um dos caminhos para se atingir esse estágio é a adoção de critérios fundamentados na ideia de programas de produtos, relacionados entre si, flexíveis em sua concepção básica, possíveis de serem modificados e adaptados com a mesma rapidez observada na evolução dos meios de comunicação. A Alberflex tinha o objetivo de se posicionar como uma empresa exemplar nesse setor.

Nas muitas visitas a feiras internacionais que realizou, Bergmiller teve muitas vezes sua atenção voltada para um fato: os padrões técnicos entre os expositores não eram muito diferentes. "Seus pavilhões eram construções muito bem feitas, com bons acabamentos, ferragens que funcionavam muito bem e seus produtos também obedeciam aos mesmos padrões; até seus preços eram relativamente os mesmos. Mas, entre centenas de participantes, os que se destacavam, com ideias diferentes, eram, seguramente, aqueles que haviam investido também em design. Esse grupo seleto sempre apresentava as novidades e as surpresas, terminando por indicar os caminhos para os próximos tempos. Seus stands eram sempre os mais visitados e a imprensa dedicava-lhes maior espaço. Nos anos seguintes os demais procuravam seguir esse caminho, mas nessa altura as empresas mais avançadas já apresentavam outras propostas. Os padrões técnicos entre a maioria das empresas eram cada vez mais nivelados por uma razão muito simples: a terceirização possibilitava que todos tivessem acesso a maquinário e componentes idênticos. Quem tivesse recursos financeiros poderia ter acesso a qualquer tipo de tecnologia. Porém, uma produção em ordem e adequada a esses padrões, não garante por si só um produto original e com personalidade. Sem dúvida já era importante que fossem respeitadas as exigências técnicas e os padrões básicos de uso e de ergonomia. Mas isso não era suficiente para se obter uma posição de destaque no mercado. Nesse aspecto particular cabe ao designer entrar em ação. Conhecer e dominar os meios tecnológicos é ótimo, mas é mais importante ainda saber usá-los com inteligência e criatividade." 
O convite para trabalhar com a Alberflex surpreendeu Bergmiller. Sua origem estava claramente na experiência desenvolvida durante a elaboração da pesquisa sobre mobiliário escolar, realizada vinte anos antes e, evidentemente, por sua conhecida atuação no setor do mobiliário para escritório durante mais de trinta anos. A Alberflex, segundo ele, estava convencida da necessidade de ter uma orientação em todas as questões relativas ao design. Bergmiller visitou a fábrica em Sorocaba, interior de São Paulo, e ficou positivamente impressionado com o potencial técnico dos equipamentos, com a organização clara e simples nas tomadas de decisões e percebeu que havia uma boa expectativa e confiança em uma colaboração sua na empresa e resolveu aceitar o que chamou de um "novo desafio".

Isso significava, principalmente, não repetir apenas experiências profissionais anteriores e aplicar estruturas de trabalho e desenvolvimento já conhecidas, evitando uma "segunda edição" de um trabalho anteriormente desenvolvido para a Escriba. Julgou necessário olhar o problema de uma forma diferente baseado em uma análise e em um diagnóstico da empresa. Mas considerou essencial uma definição de parâmetros para futuros projetos que permitiriam chegar a uma "identidade própria de produtos". No ensino Bergmiller sempre enfatizou a "disposição permanente para as experiências". Mas, experiência para ele nunca foi um processo aleatório, limitado a um simples voluntarismo, sem uma objetividade previamente traçada. No caso de empresas é ainda mais enfático e afirma que "nenhuma empresa participa de aventuras, pois qualquer experiência deve basear-se em procedimentos metodológicos, resultando em uma resposta a uma questão previamente estabelecida".

Ele destaca que, no primeiro encontro com a direção da Alberflex, não foi necessário perguntar qual seria a sua tarefa na empresa: essa definição seria dada por ele mesmo. O que a empresa queria era a definição de conceitos claros e convincentes, propostas para um método de aperfeiçoamento no projeto e no planejamento geral de seus produtos e também critérios que orientassem uma conscientização geral em relação às suas qualidades técnicas, funcionais e formais. "Design se faz"— já havia dito há muitos anos Hans Gugelot, conforme registro na revista ulm, n 10 de 1964. Mas, só se faz quando o empresário e sua equipe estão bem afinados e relacionados com o designer, compartilhando os mesmo objetivos. Nesse caso, o design pode-se transformar em uma política empresarial, em norma de conduta que influi tanto no projeto e no planejamento dos produtos, como em sua comercialização e na comunicação com colaboradores, fornecedores e clientes. Design não pode ser um segmento isolado em uma organização. Na verdade, nas concepções de Bergmiller, uma empresa cuja oferta seja "duvidosa", dificilmente conseguirá criar um canal de venda para um bom produto: "Numa empresa mal gerida nunca se poderá desenvolver um trabalho de design."

"O projeto de produtos industriais em grande escala necessita às vezes de muitos anos de desenvolvimento e de preparo para sua fabricação. Até se ter segurança sobre sua viabilidade no mercado, existe um longo trajeto que não 
A Alberflex, desde a época em que era fabricante de mobiliário escolar, investiu em maquinário e equipamentos sofisticados e de alta produtividade. Mas, passar para outro tipo de produto, o móvel de escritório, exigiu da empresa um trabalho bastante complexo. Em determinado momento, a empresa percebeu que esse processo poderia ser mais bem desenvolvido com a colaboração do design, pois as exigências não se restringem apenas aos produtos físicos. A própria imagem da empresa, sua visualidade e outros fatores deveriam ser modificados e atualizados, permitindo uma inserção mais objetiva num mercado novo e diferente do que trabalhara até então. Em prazo mais curto, a ideia era racionalizar a oferta de produtos $d a$ Alberflex e, em um prazo maior, desenvolver novas linhas de produtos.

$A$ atividade do designer em uma empresa pode começar com a conscientização de todos sobre a natureza do próprio trabalho. Nada mais instrutivo do que acompanhar e participar do processo de concepção de um produto, de sua correta fabricação e de sua inserção no mercado. Essa é a melhor forma de interpretar em seguida as reaçôes do consumidor, podendo argumentar, esclarecer e defender um produto consistentemente. $O$ diálogo entre os integrantes dos departamentos de design, planejamento, produção, administração e vendas entre si e com a direção da empresa é essencial para o sucesso. se restringe ao desenho e à concepção formal e funcional. Riscos de investimento devem ser previamente avaliados, principalmente no sentido de serem minimizados. Investimentos em tecnologia não são limitados a máquinas e equipamentos e em substituições de materiais e processos de fabricação. Uma empresa realmente contemporânea deverá sempre entender que seu principal investimento é feito em inteligência e em seu pessoal, desde aqueles que se responsabilizam pela concepção e pelo projeto de seus produtos, até aqueles que tornam sua fabricação viável e racional, que sabem como colocar esses produtos no mercado e que administram todo esse processo de forma clara e transparente. Uma empresa que tenha esse objetivo não pode prescindir do design.

A colaboração de Bergmiller com a Alberflex se estabeleceu com esse sentido, iniciando-se em novembro de 1999. Segundo ele,

numa primeira análise dos dados então disponiveis sobre a oferta de produtos, a capacidade de fabricação e a posição da empresa no mercado de mobiliário para escritório, ficou claro que não se deveria propor nenhuma mudança drástica, radical e imediata, que poderia colocar em risco a posição da empresa. Também não era o momento adequado para a proposição do desenvolvimento de novos produtos, acrescentando mais elementos a uma oferta já bastante significativa. O trabalho inicial mais importante seria elaborar um referencial de racionalização das linhas de produtos, muitas delas variantes de outras anteriores que, eventualmente, até atrapalhavam a programação racional de sua fabricação, na maior parte das vezes sem grandes vantagens comerciais. Era mais importante fazer correçôes e alteraçôes que não implicassem investimentos, que não perturbassem os métodos de venda e nem alterassem, de imediato, os padróes existentes, mas que fossem, aos poucos, elevando sensivelmente seus critérios técnicos e suas qualidades funcionais e formais. Dentro de uma oferta de produtos bem estruturada e inter-relacionada, futuros projetos encontrarão sempre um ambiente e uma vizinhança mais apropriados e consistentes.

Paralelamente à reformulação da linha de produtos, percebeu-se também a necessidade de se reformular a própria identidade corporativa da empresa, tarefa que naturalmente foi desenvolvida por Bitiz Afflalo e Associados, que já trabalhara para a Alberflex anteriormente e tinha também mantido contato com a empresa com a participação de sua titular no projeto do mobiliário escolar do IDI/MAM para o MEC/CEBRACE. O resultado da primeira etapa desse trabalho foi um novo logotipo e a programação de uma identidade aplicada a todos os elementos da empresa, incluindo-se material promocional, anúncios, fachadas de lojas e veículos. Depois da edição de seis catálogos, percebeu-se que a Alberflex falava uma nova linguagem para todos. Foi um sinal claro de que o design passara a fazer parte da política da empresa.

Essa nova identidade evidenciou-se com a presença em feiras como a Office Solution nos anos 2000, 2001 e 2004. A participação nesses eventos implica custos relativamente altos, já que a rotina da produção cotidiana e o planejamento geral ficam durante algum tempo comprometidos com tempo extra- 
Desenvolver um trabalho dessa natureza numa empresa já sólida e bem- estruturada pode ser visto como um trabalho dificil. Mas, qualquer trabalho sério não é simples. Não se pode pensar em repetir ou aplicar conceitos que deram certo em outras épocas e em outras circunstâncias. Em cinco anos de trabalho, algumas coisas mudaram. Os produtos da Alberflex apresentam, certamente, caracteristicas formais diferentes. Mas também o pessoal envolvido na produção, na venda e em outros aspectos, opina e participa de forma intensa nesse processo, o qual não tem prazo definido, o que caracteriza muito mais um processo que um projeto de produto. Um designer sempre deve ser realista, mas deve também sempre projetar visando a um tempo futuro, que não é necessariamente definido apenas a partir de prazos restritos. ordinário dedicado ao evento. Por outro lado, é importante que uma empresa inovadora apresente sistematicamente para o público suas respostas às novas demandas de trabalho e, até mesmo, tente antecipar-se a esse fenômeno. Por isso essa presença ganha importância e significado interno, além do caráter promocional e de vendas que, provavelmente, só acontecerá num prazo maior. Feiras podem ser até mesmo uma ótima ocasião para avaliar o que a empresa tem realmente de novo a oferecer e, por isso, devem ser encaradas com seriedade e dentro de cronogramas bastante precisos.

Renato De Fusco, historiador italiano especializado em design e arquitetura, em seu livro Storia del design (Bari: Laterza \& Figli, 1988), diz que existem quatro principais momentos de ação do design: o projeto, a produção, a comercialização e o consumo e que eles não devem se apresentar de forma autônoma ou mesmo separada. A convergência desses quatro momentos é essencial e sem ela o design dificilmente pode existir. Bergmiller sempre ressaltou que a participação em feiras deveria servir também a finalidades de estimular essa convergência. Sempre afirmou que apresentar-se para um público externo, formado principalmente por profissionais, especificadores de mobiliário, era uma ocasião propícia para a avaliação do trabalho em comparação com a concorrência. A feira, além disso, tem prazos definidos, servindo muitas vezes para a aceleração de projetos em desenvolvimento. Nesses eventos, considera ele, "é sempre importante chegar com surpresas e, além disso, nessas ocasiões, todos os integrantes da empresa, os que planejam, que projetam, que fabricam, administram e vendem podem ter uma visão do potencial e da organização a que pertencem; isso pode ajudar a elevar a sua autoestima. Se uma feira for avaliada exclusivamente sob o ponto de vista de um retorno comercial imediato, é melhor não participar e investir em outras formas promocionais."

As considerações de Bergmiller relativas à participação em feiras apresentam uma característica importante de suas ideias. As questões relacionadas com aspectos práticos e comerciais são importantes mas, por trás delas, aparece uma concepção básica:

Projetos industriais necessitam, muitas vezes, de prazos extensos e as feiras não são realizadas em função de uma ou outra empresa, mas de seu conjunto. Corre-se sempre o risco de apresentar trabalhos ainda pouco amadurecidos apenas pela necessidade de estar presente à feira, principalmente porque o mercado tornou-se muito competitivo. Porém, uma empresa séria não pode fazer isso. Se ela não estiver em condiçóes de apresentar novidades consistentes ela deverá realmente analisar se vale a pena participar apenas para marcar uma presença e, se achar que sim, poderá recorrer a seus produtos já em produção, a argumentos que salientem suas qualidades técnicas, suas boas características de uso e outras. Nesse aspecto é importante dizer que aquelas empresas que investem em produtos de longo prazo estarão sempre em posição mais confortável. 


\section{Linha 900}

A idéia para esta linha de móveis era atender a todas as demandas funcionais e hierárquicas de um escritório atual, com a mesma qualidade técnica, funcional e formal em todos os níveis. A Alberflex preencheria assim uma lacuna em sua oferta de produtos, pois essa linha seria dirigida a um usuário menos tradicional, mais seletivo e exigente.

O que se constatou foi que além de ser uma linha mais completa, essa linha era também a mais econômica de todas, formada por sete tipos de móveis, classificados por suas finalidades, podendo ter sua tipologia ampliada futuramente: mesas de trabalho, mesas para reunião e conferências, estações de trabalho, mesas para informática, mesas para telemarketing, sistema de balcões e mesas de múltiplo uso.

A linha 900 baseia-se num sistema construtivo simples e eficaz, a conexão de dois tubos por um parafuso. Nenhum móvel industrializado é vendido e transportado montado. Isso deve acontecer no espaço do cliente. Para o transporte é importante a redução do volume que, no caso desta linha chega a $80 \%$. Outra vantagem é que o tempo de montagem de uma mesa com quatro pés da linha 900 é estimado em um minuto. Quando se instalam grandes espaços de trabalho, é importante que isso seja feito de forma rápida e limpa. A montagem do espaço deve ser considerada a última etapa da fabricação e deve seguir todos os conceitos definidos para o processo geral do produto.

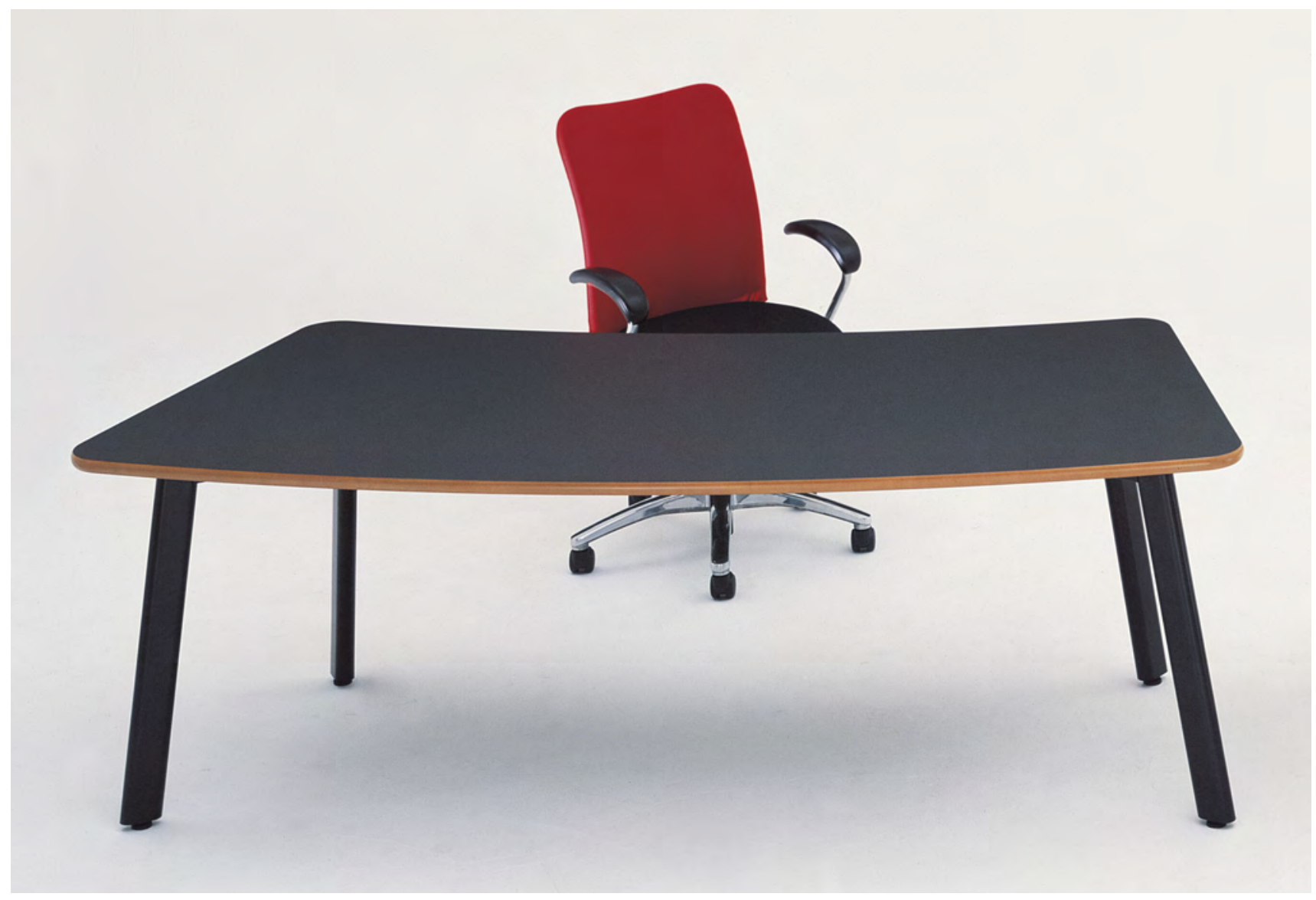


900| mesas de trablho

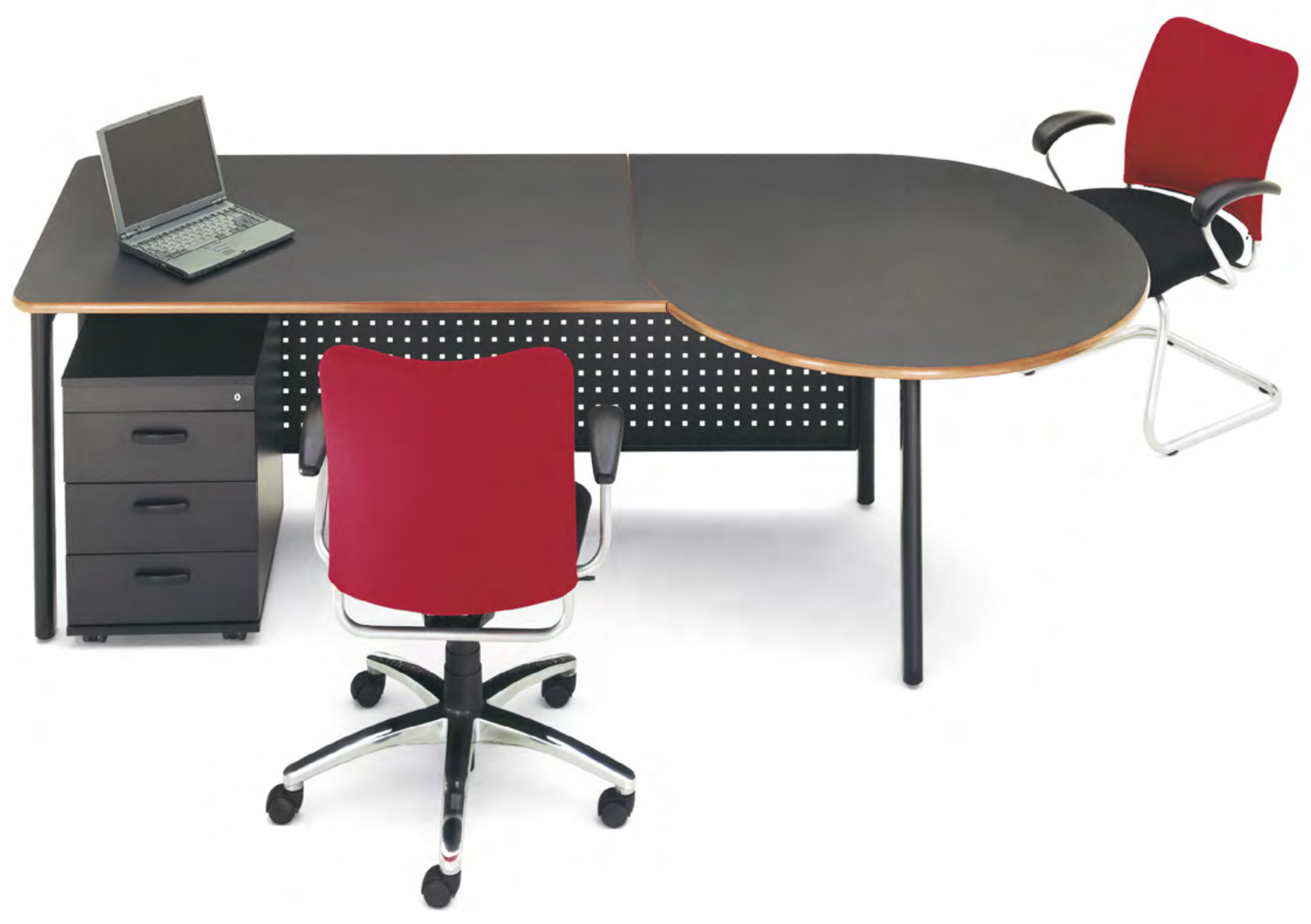

Mesas com superfície de reunião acoplada facilitam atividades no cotidiano. 


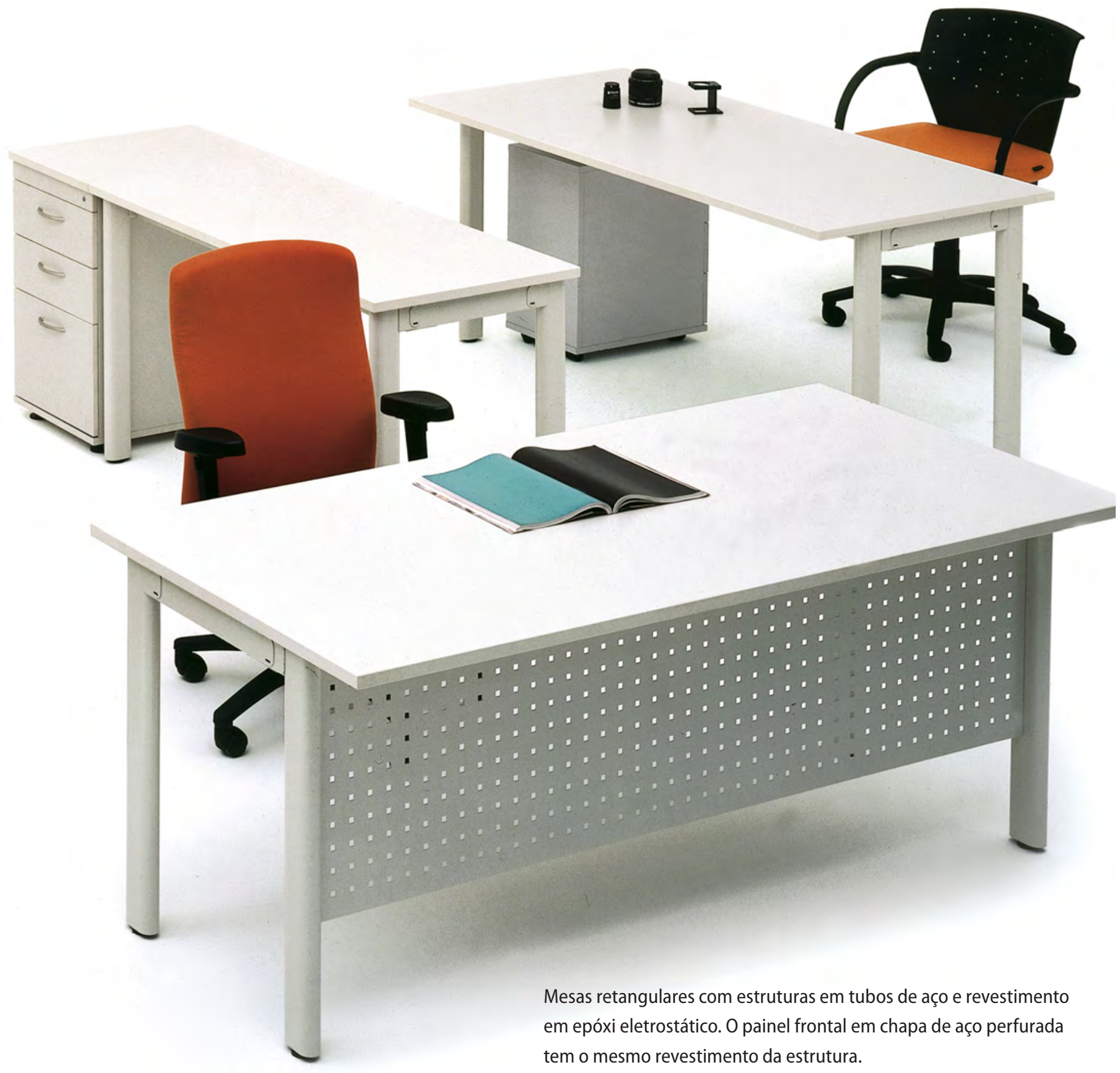


$900 \mid$ mesas curvas

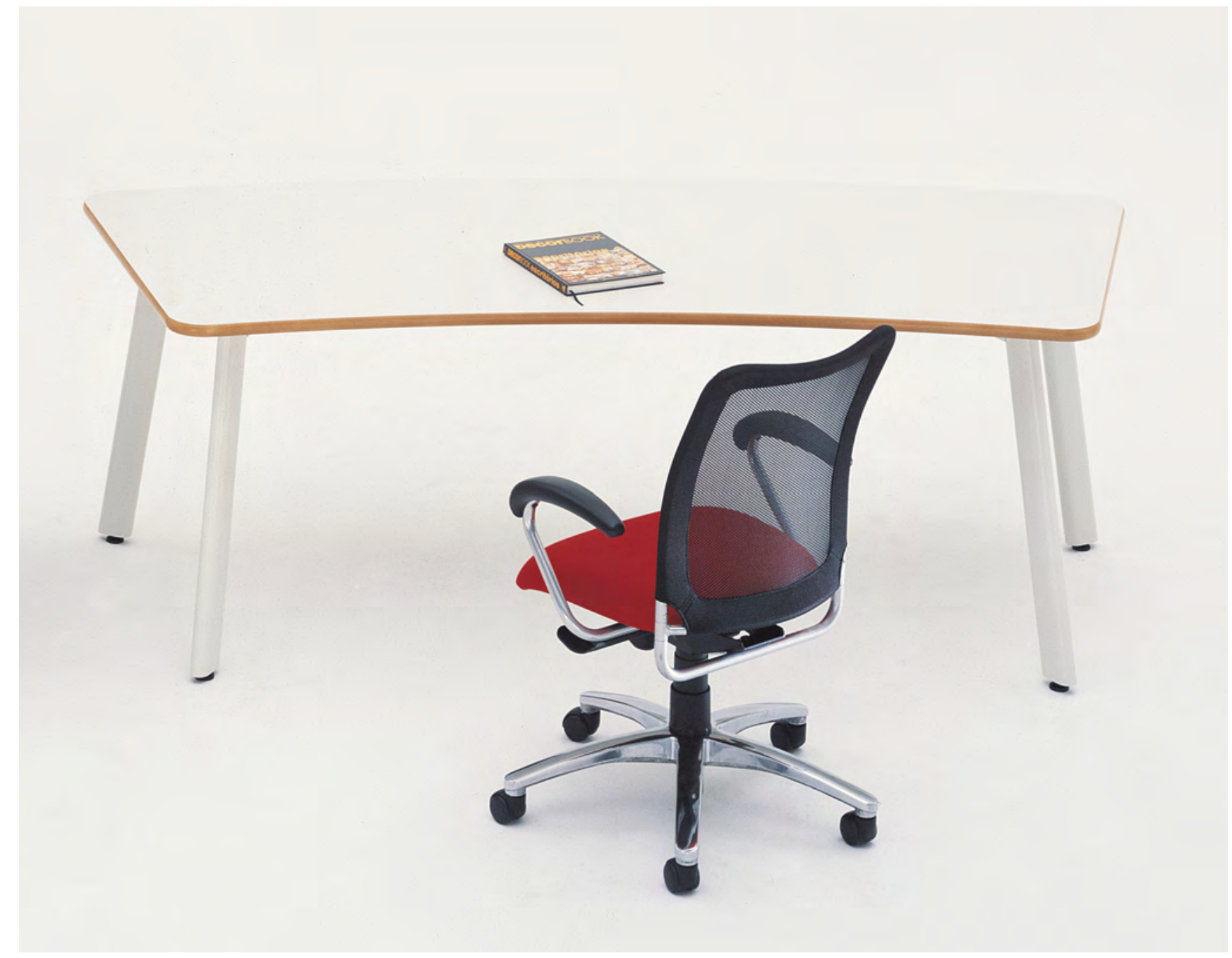

As superfícies de trabalho podem receber acabamento em madeira natural pré-composta e bordas também em madeira. 

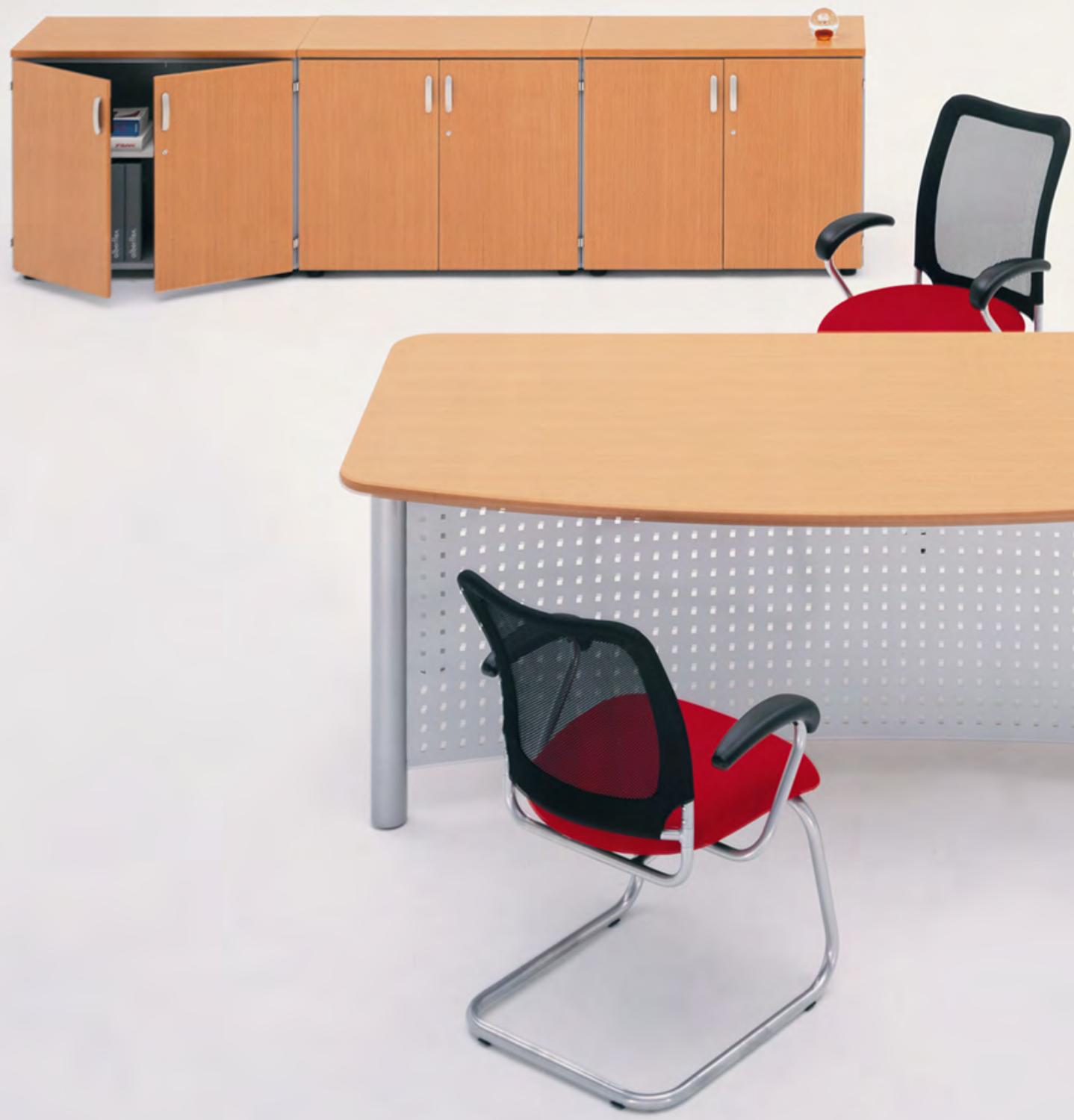

Detalhes técnicos: tampo curvo assimétrico, pés de seção circular, e painel frontal em chapa de aço perfurada e curvada de forma côncava em relação ao tampo. 


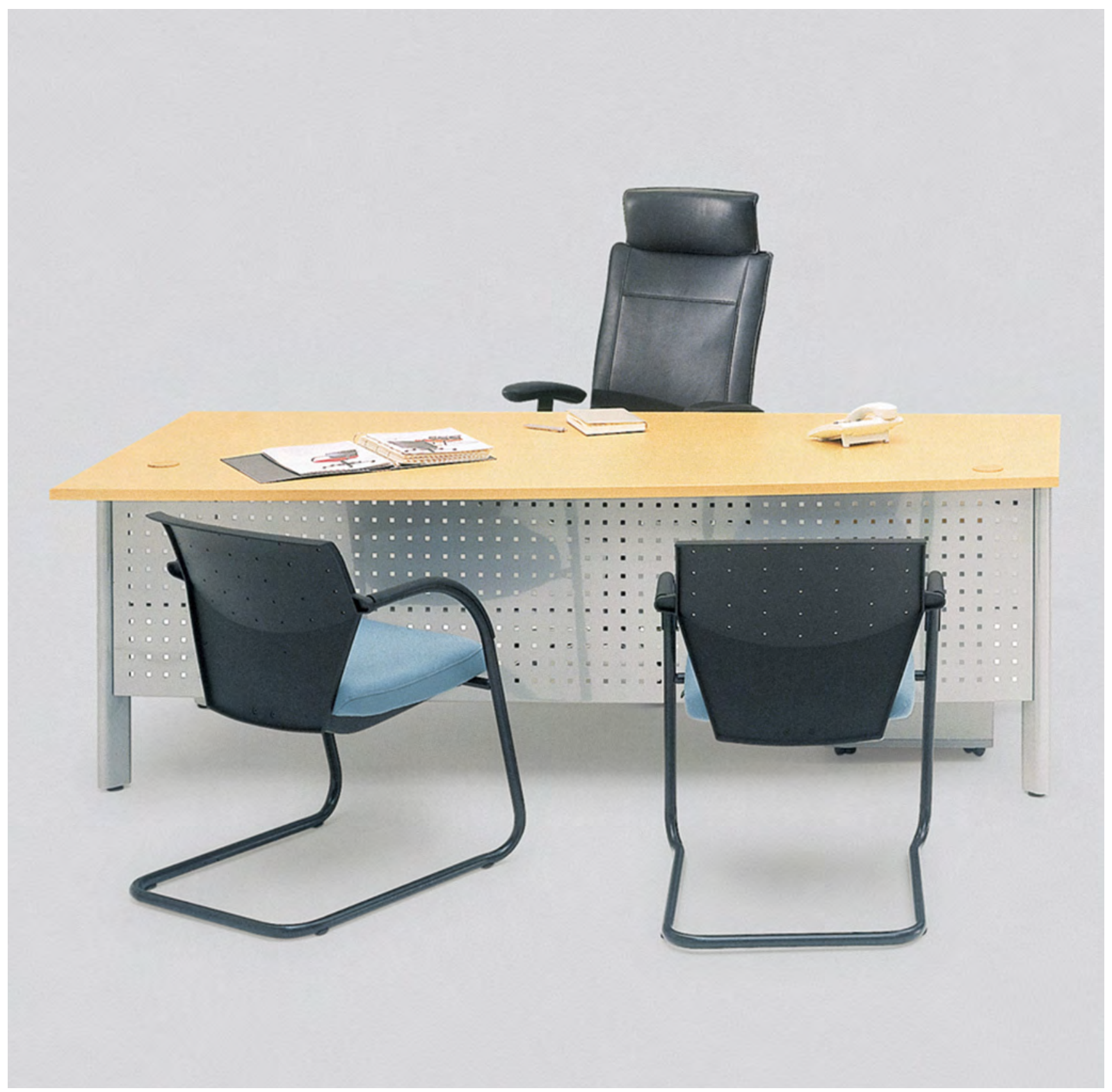

Detalhes técnicos: tampo curvo simétrico, pés de seção circular, e painel frontal em chapa de aço perfurada e curvada de forma côncava em relação ao tampo. 


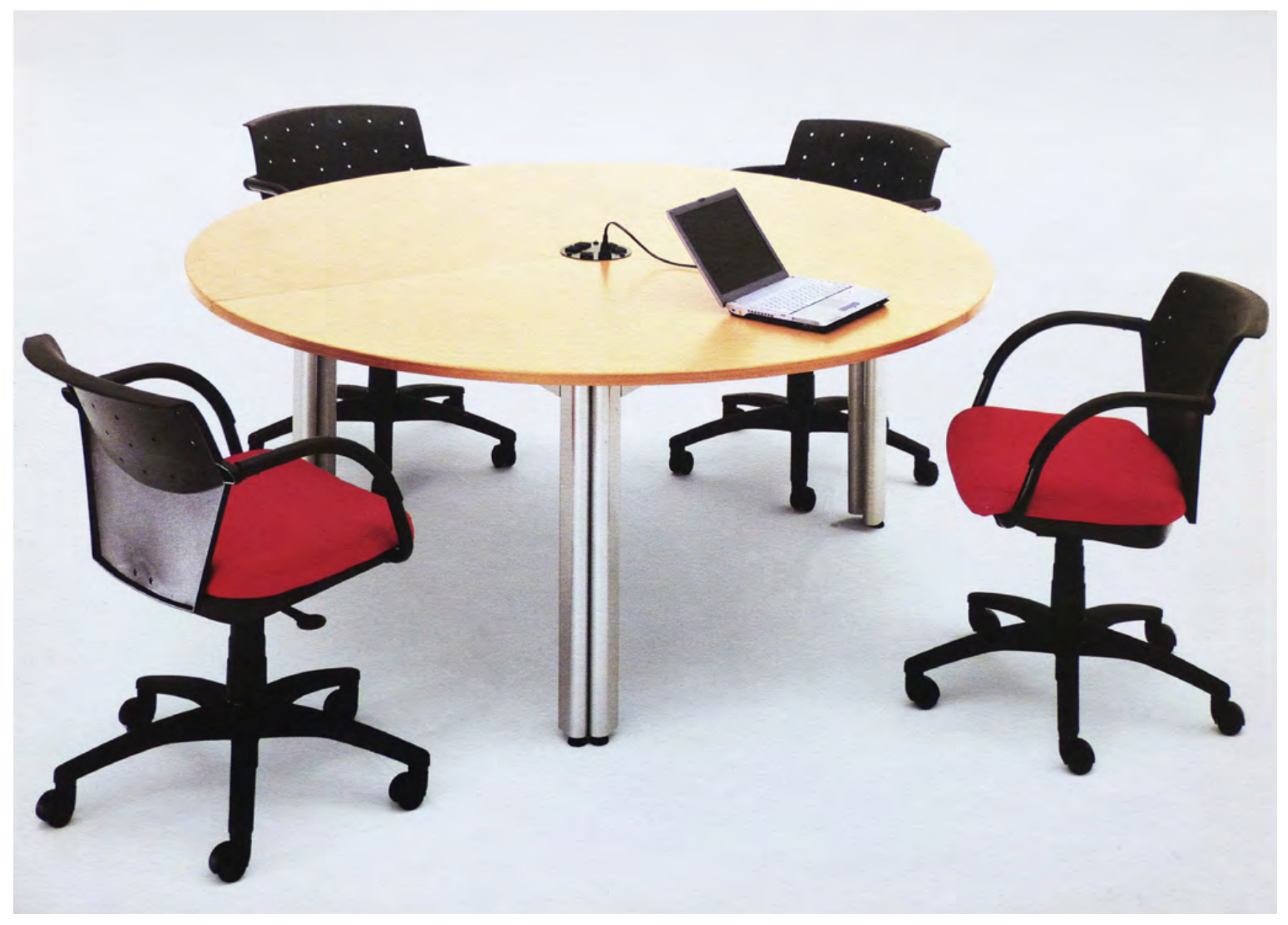


900 | mesa de reunião

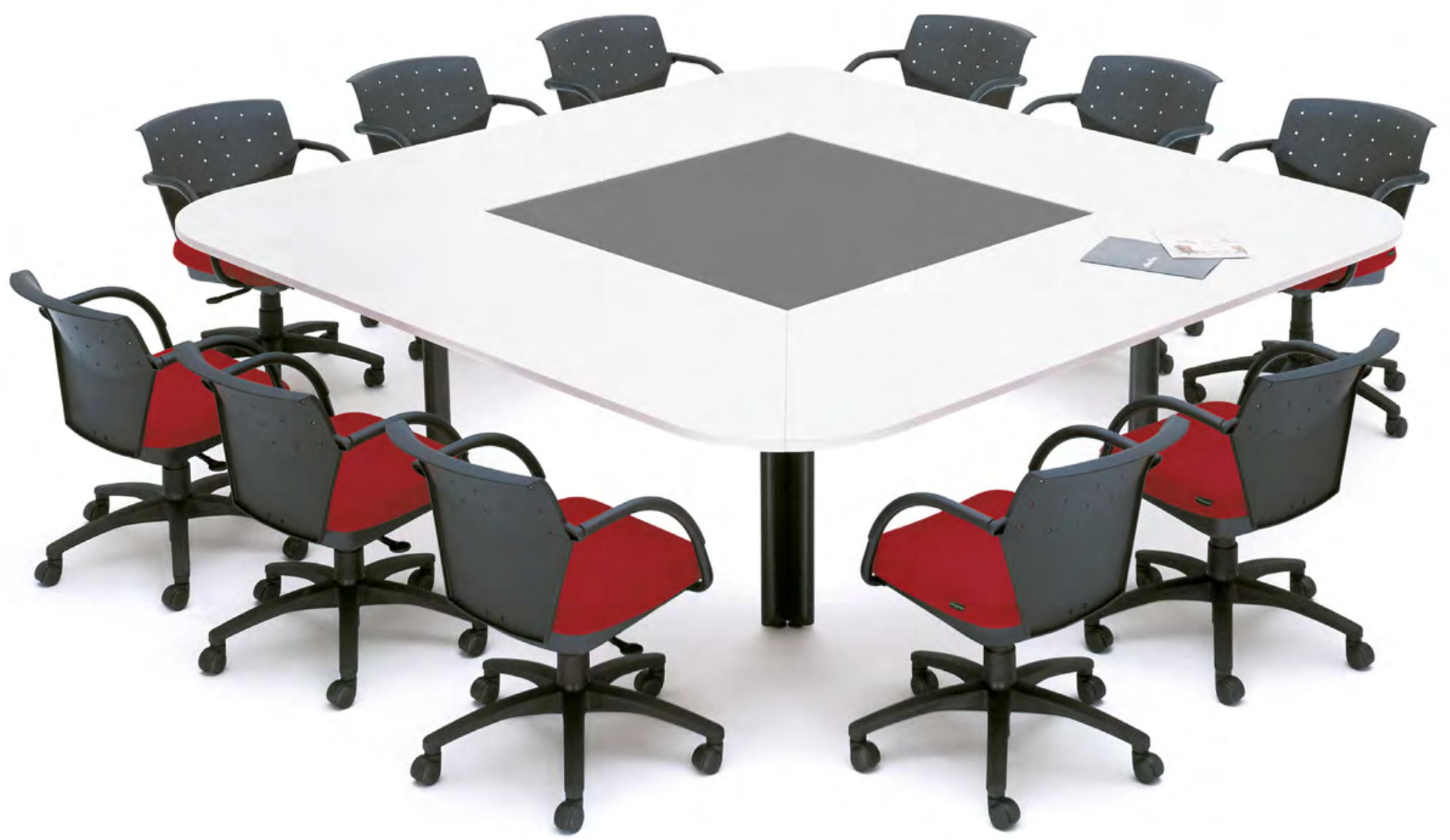

Mesas de reunião com suporte para instalação elétrica, eletrônica e telefonia. 


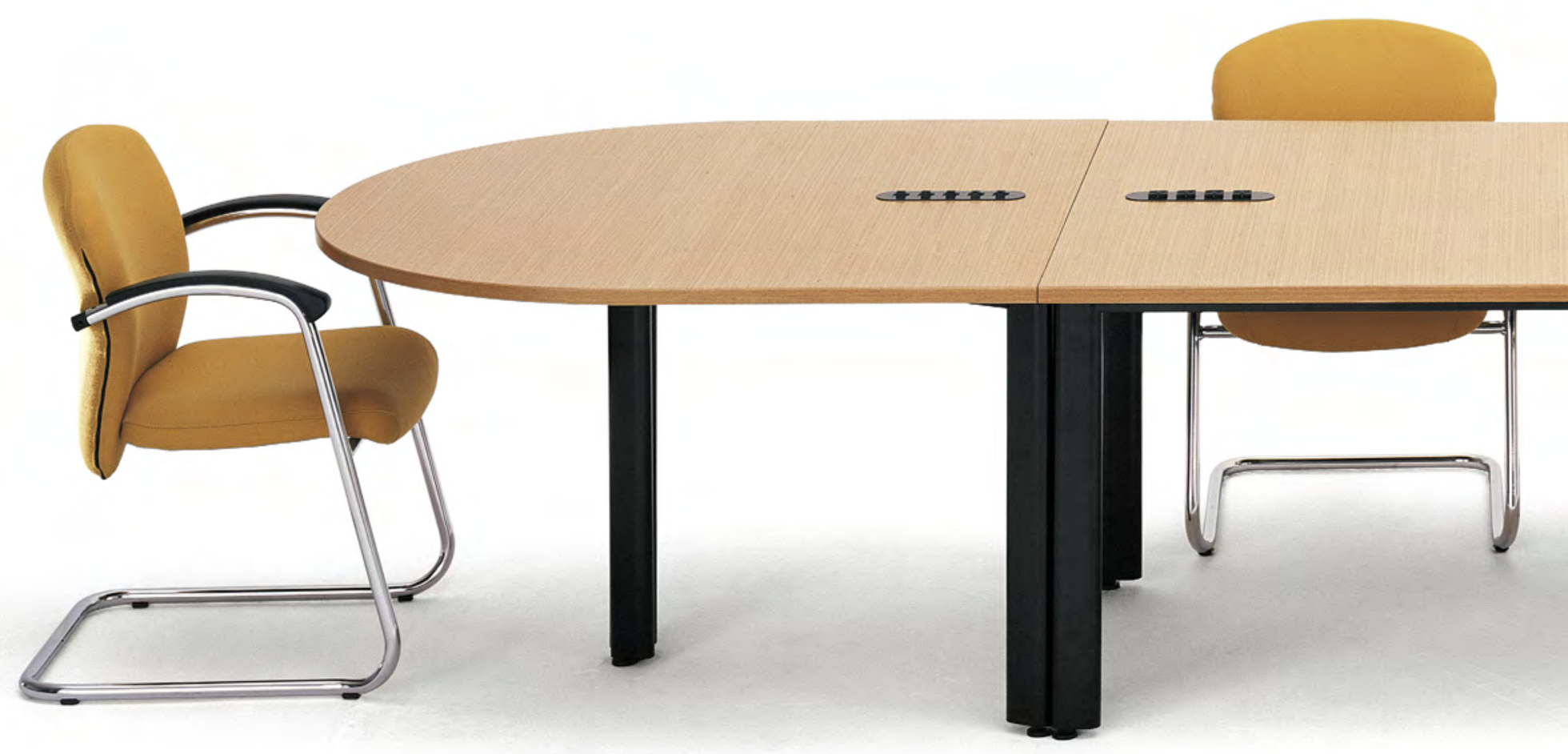


900 | mesa de reunião componível

06 a 08 lugares $240 \times 120 \mathrm{~cm}$

08 a 10 lugares $320 \times 120 \mathrm{~cm}$

08 a 12 lugares $320 \times 120 \mathrm{~cm}$

12 a 14 lugares $480 \times 120 \mathrm{~cm}$
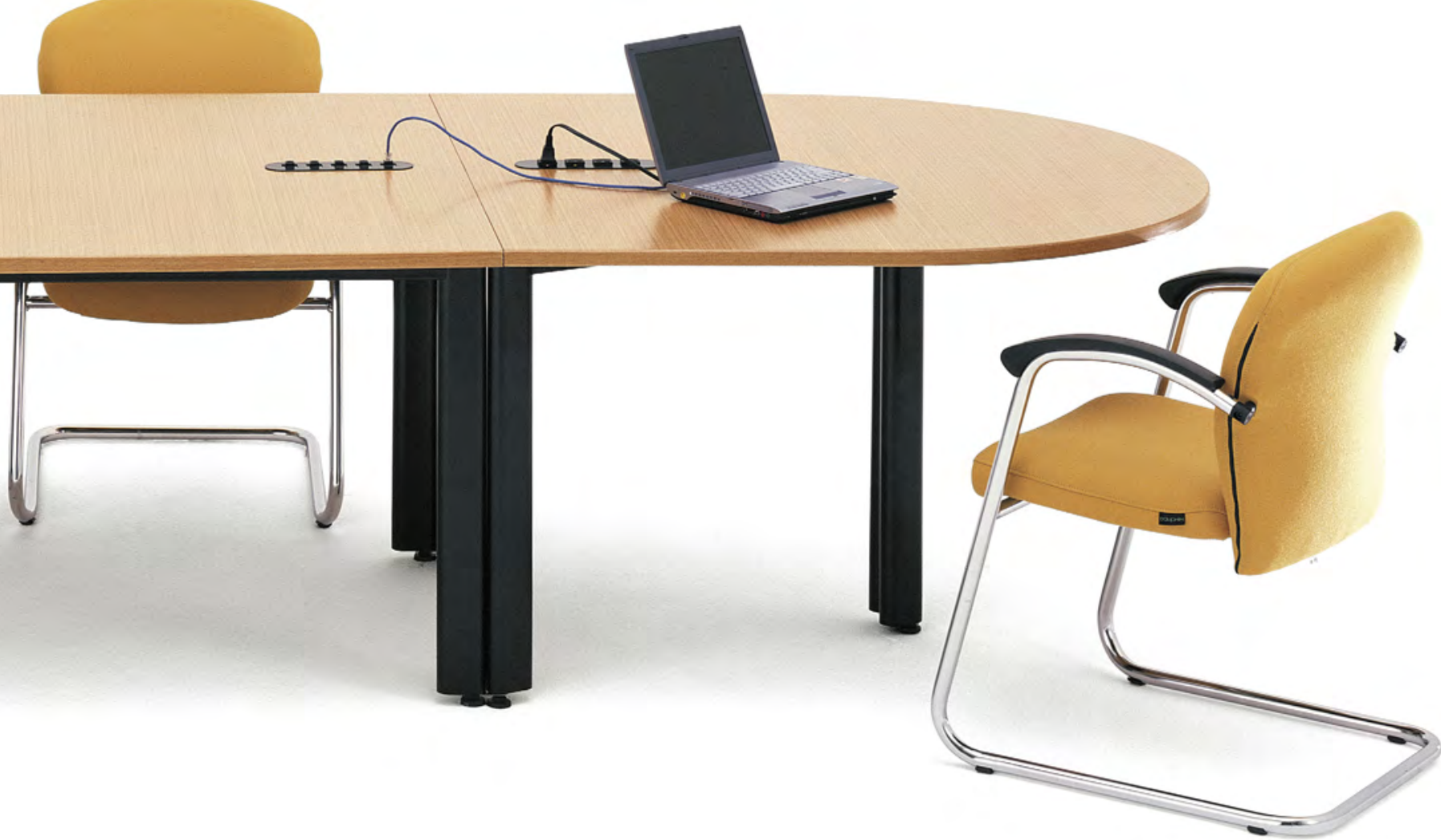


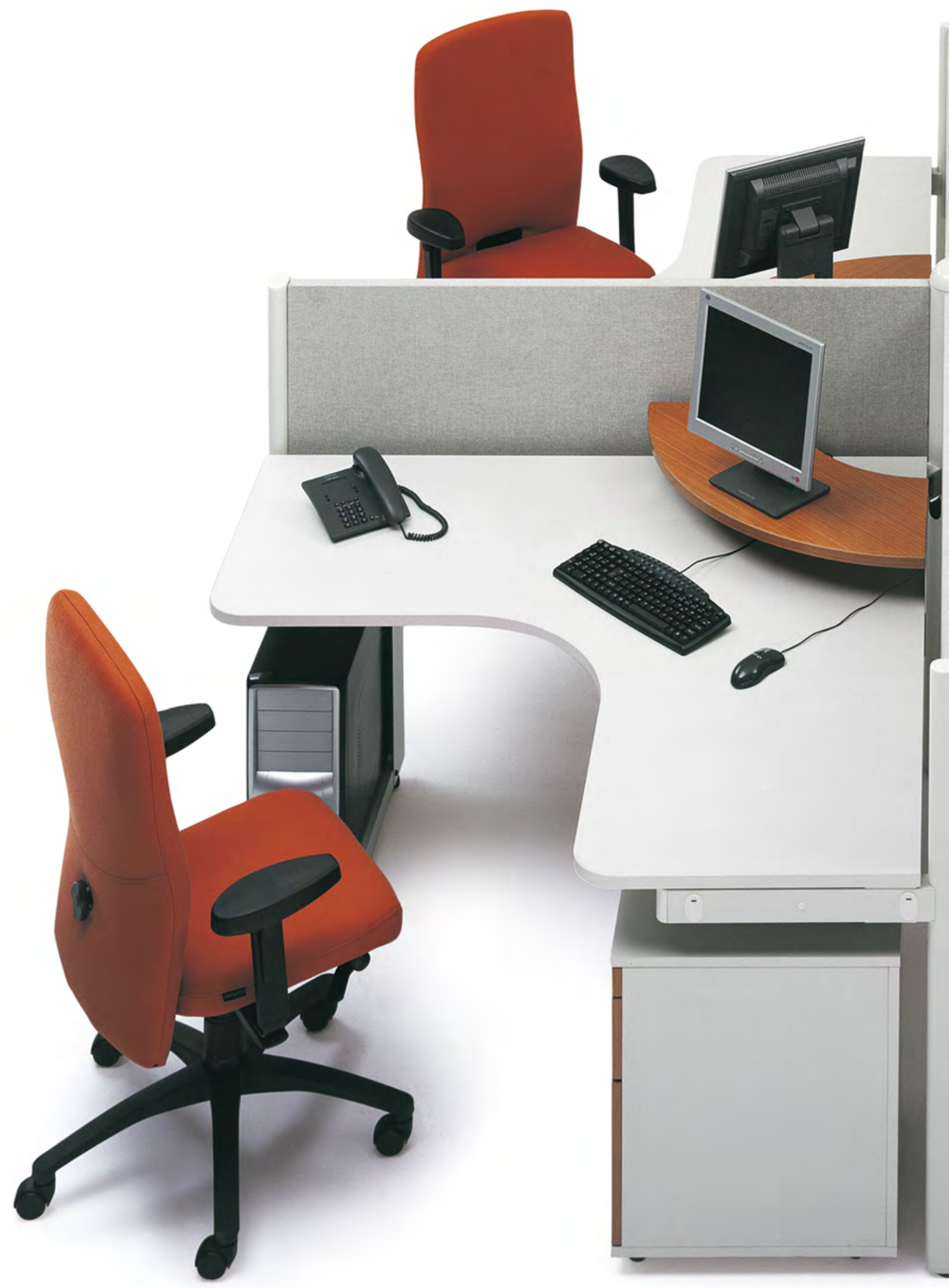




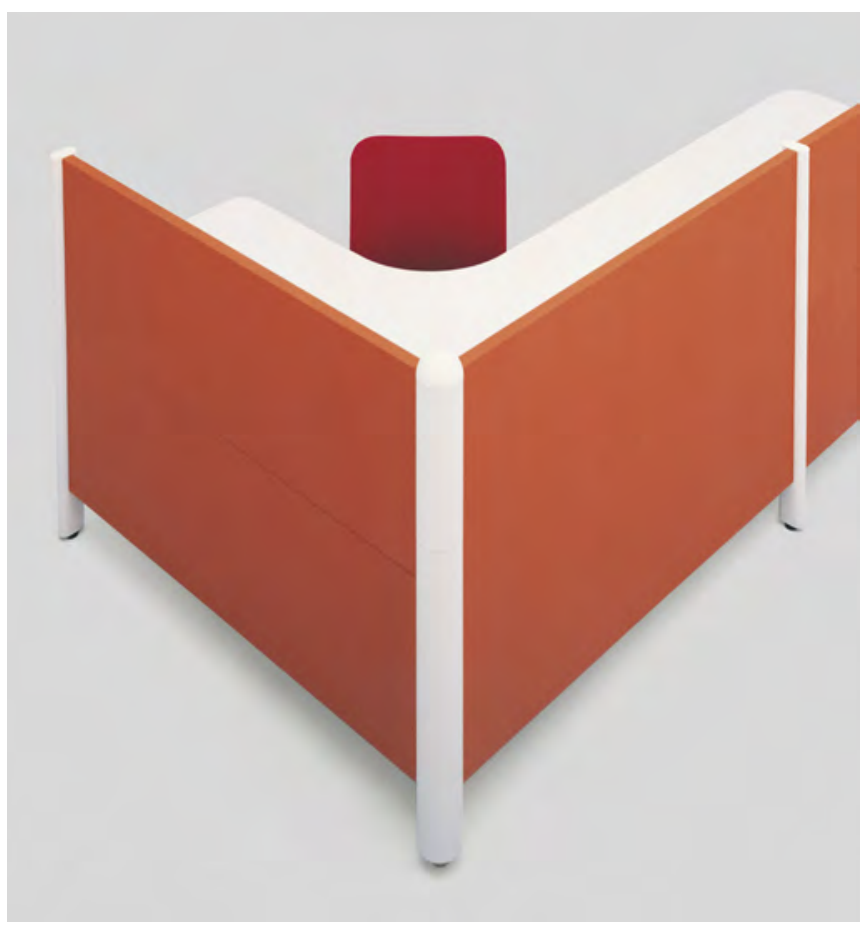

900 | estações de trabalho

\section{detalhes técnicos}

tampos em madeira aglomerada

revestidos com laminado melamínico.

estrutura em tubos de aço revestidos

em epóxi eletrostático, nas cores preto, cinza ou argila.

painéis revestidos em tecido ou fabricados em chapas de aço perfurada, com o mesmo revestimento da estrutura.

\section{legenda da perspectiva explodia}

1 tampo em balanço de $40 \mathrm{~cm}$

2 caixa de tomadas elétricas

3 conjunto de tampos

4 coluna terminal

5 tampo central padrão

6 tampo complementar esquerdo $70 \mathrm{~cm}$

7 painel divisor

8 suporte para monitor

9 painel divisor

10 suporte para monitor

11 conjunto de 4 tampos

| acoplar à esquerda

12 coluna central com 4 saídas

13 tampo semicirculo em balanço

14 tampo complementar reto

15 caixa de tomadas elétricas

16 estrutura padrão

17 calha para cabos 


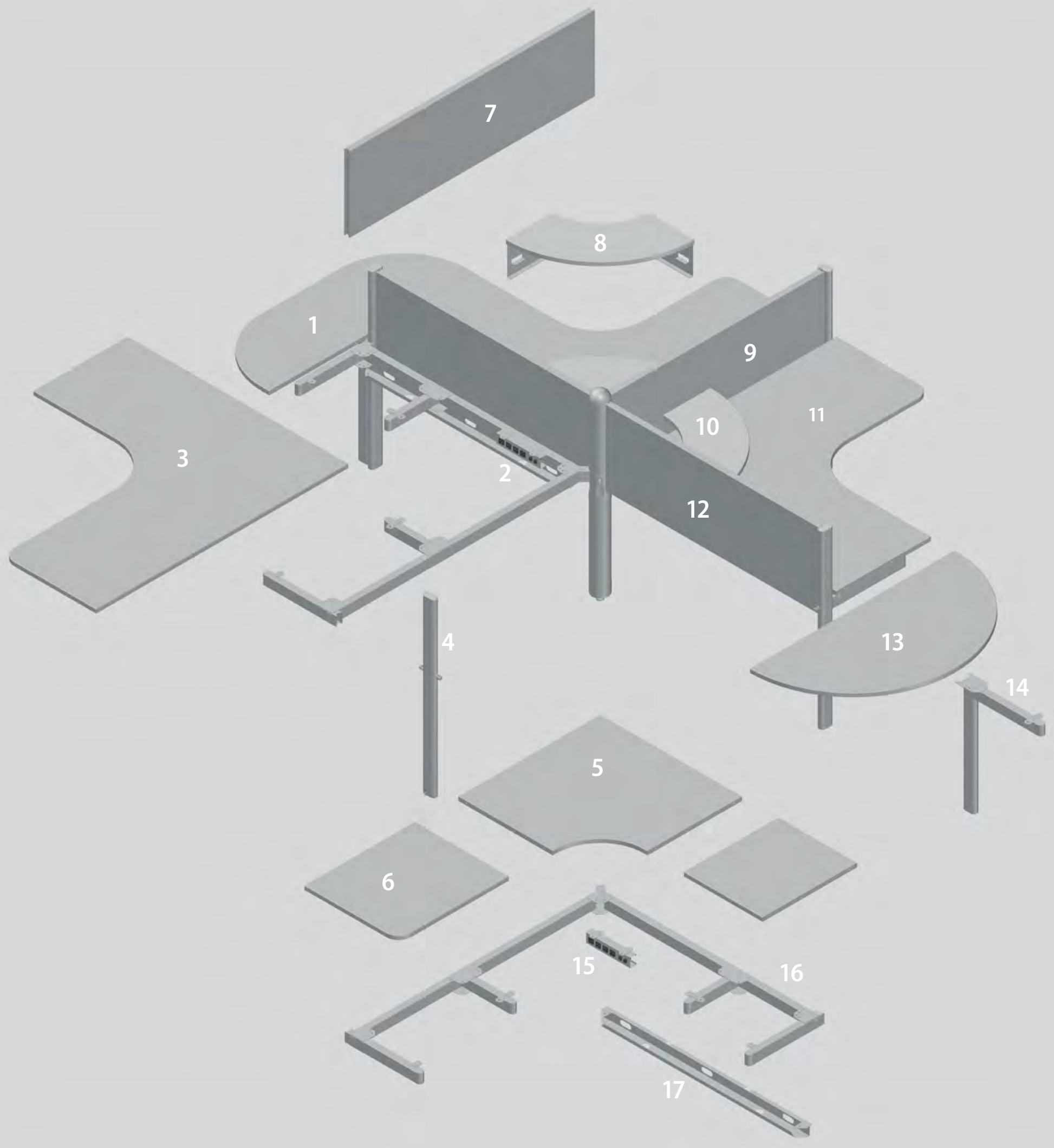




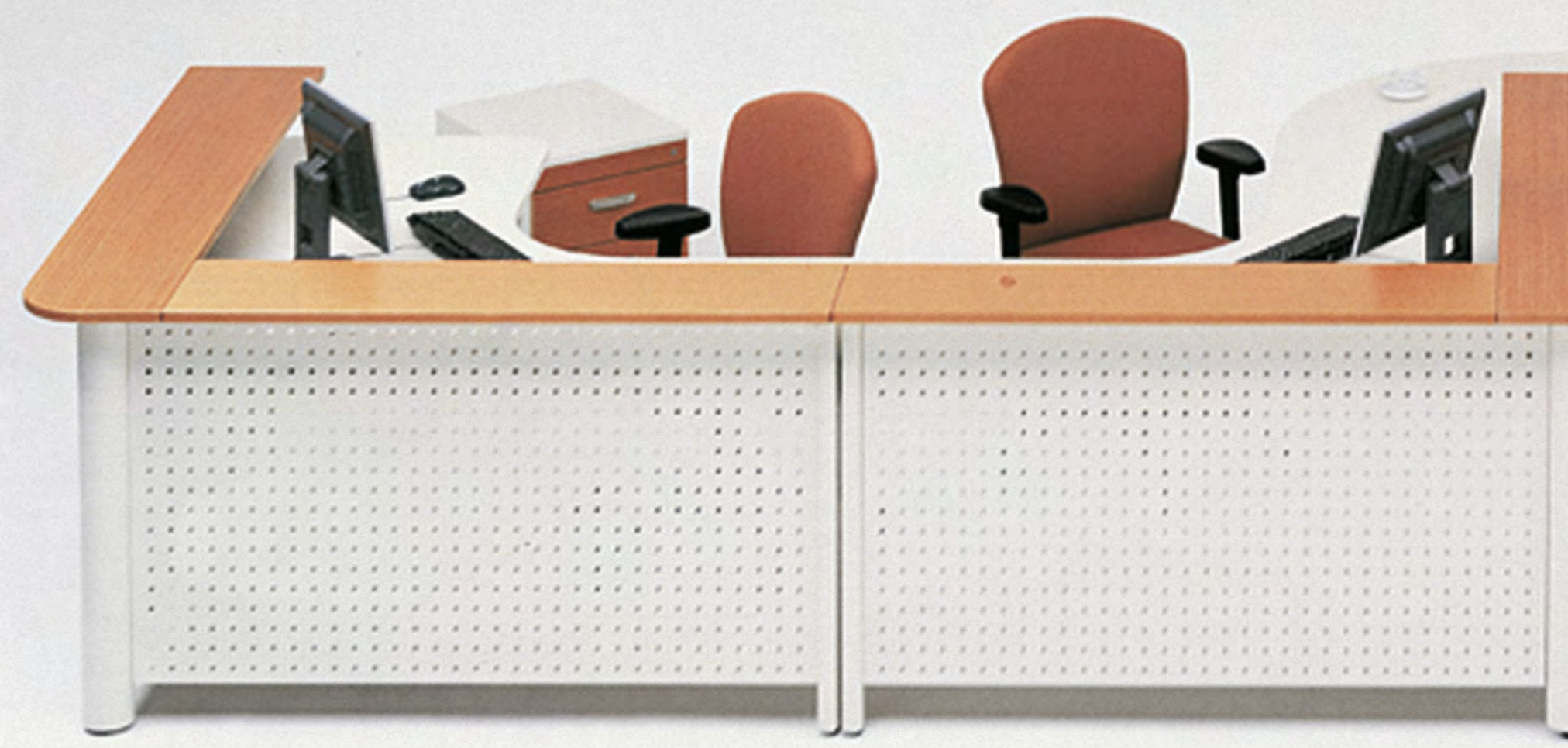


900 | painéis e balcões integrados a estações de trabalho
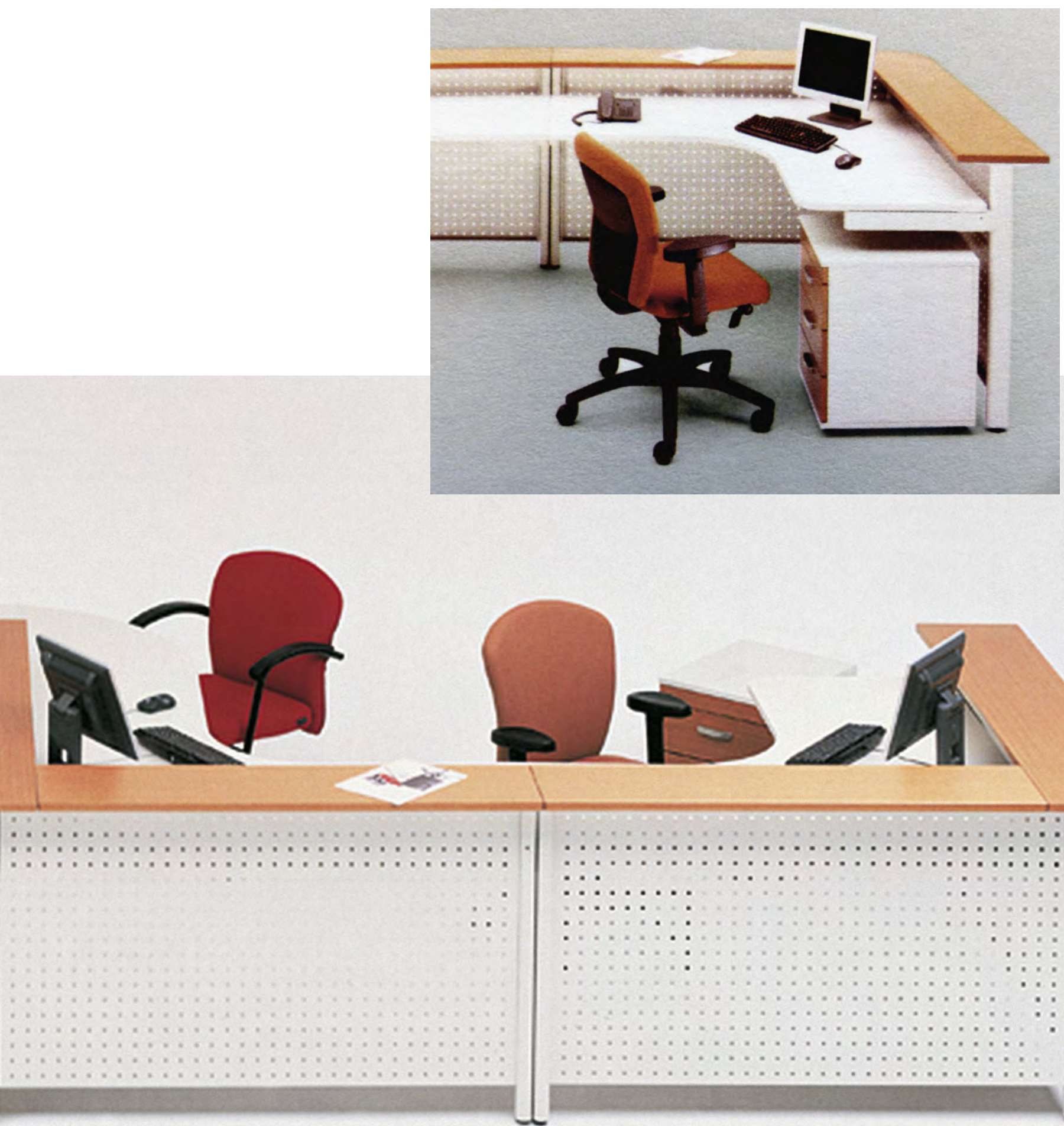

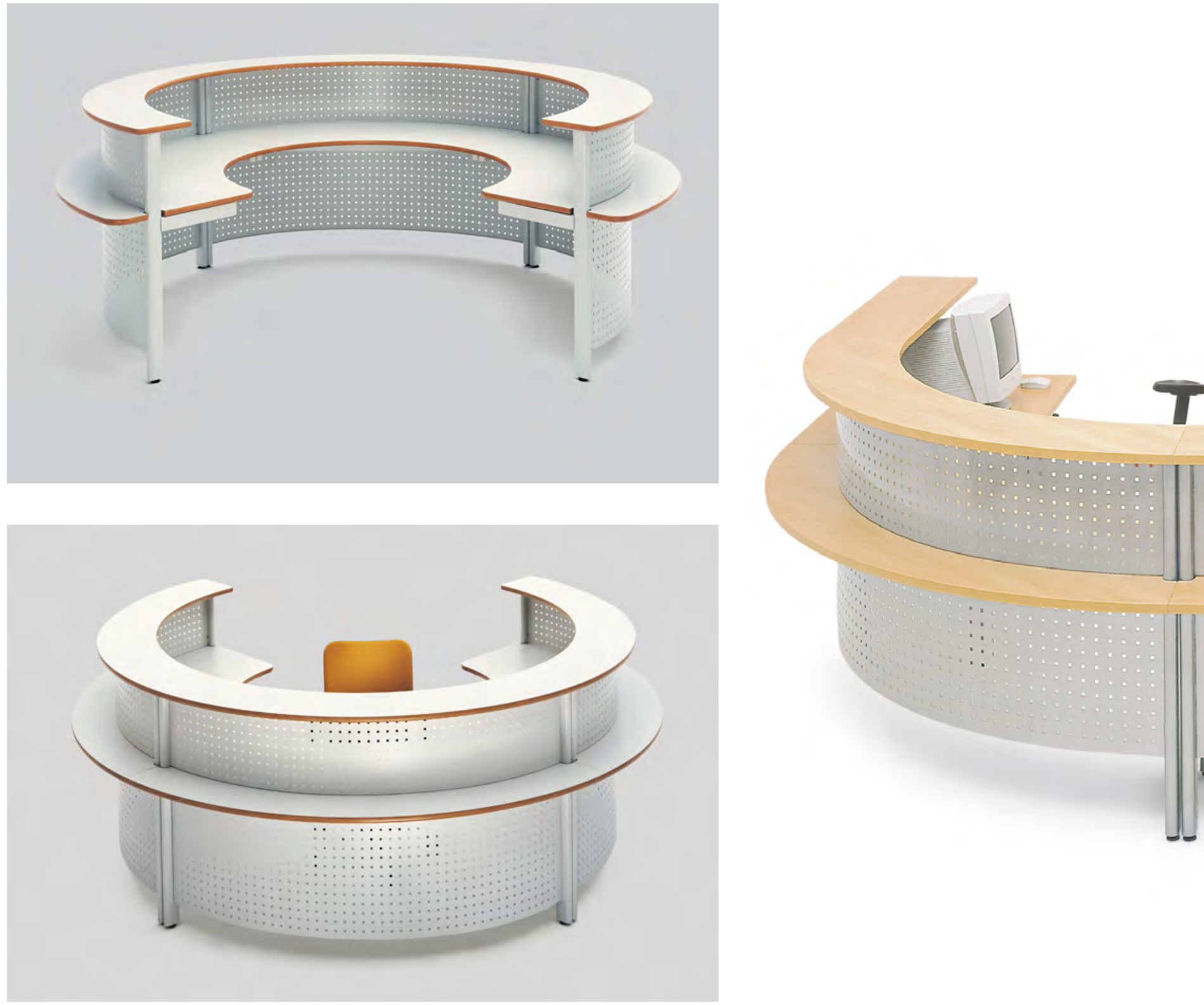
$900 \mid$ sistema de balcões

O balcão é um móvel de referência para a pessoa que deseja estabelecer um contato, contratar um serviço ou buscar uma informação.

O balcão cria um espaço de atendimento e apoio físico que permite estabelecer uma interlocução.

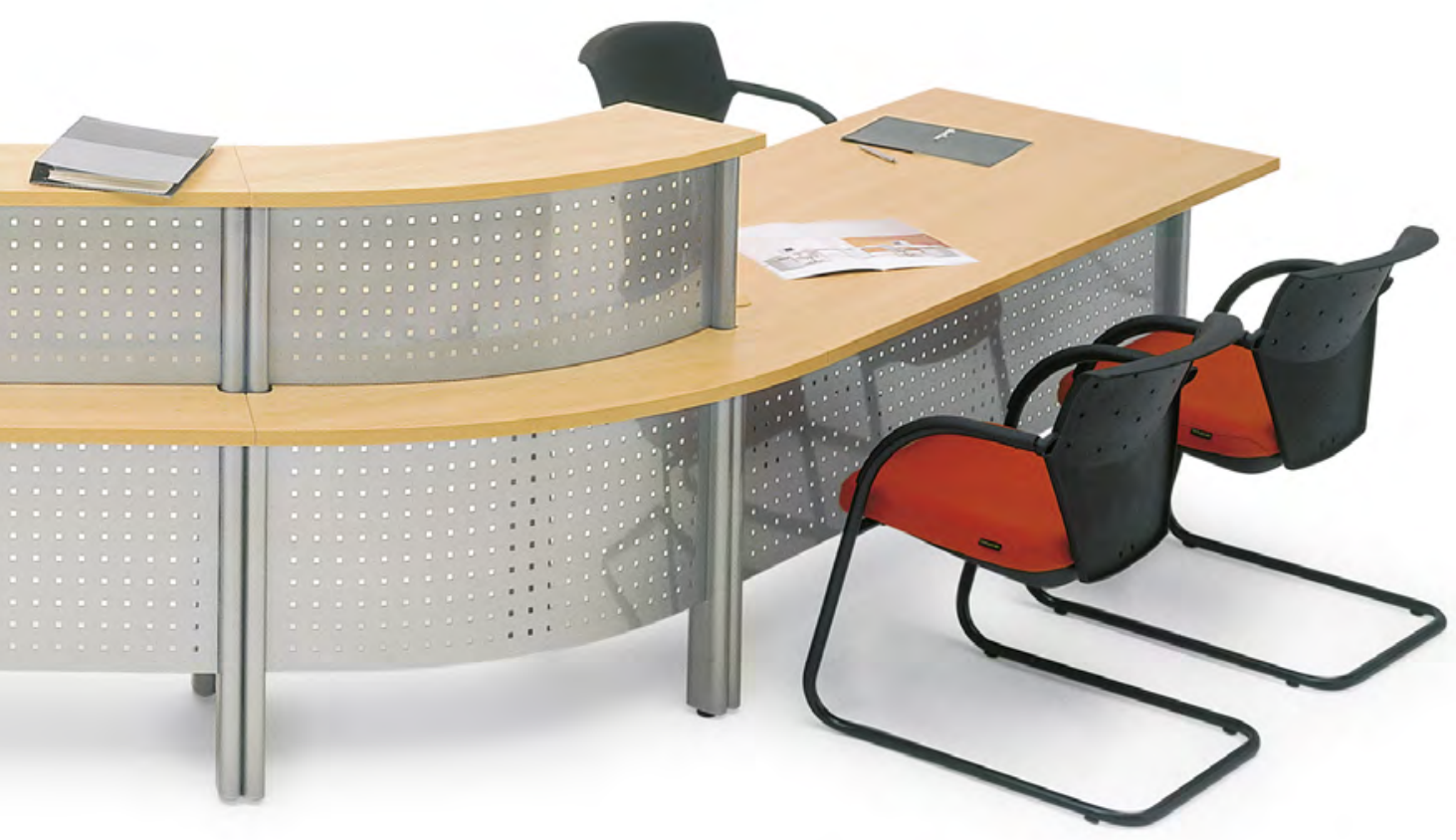




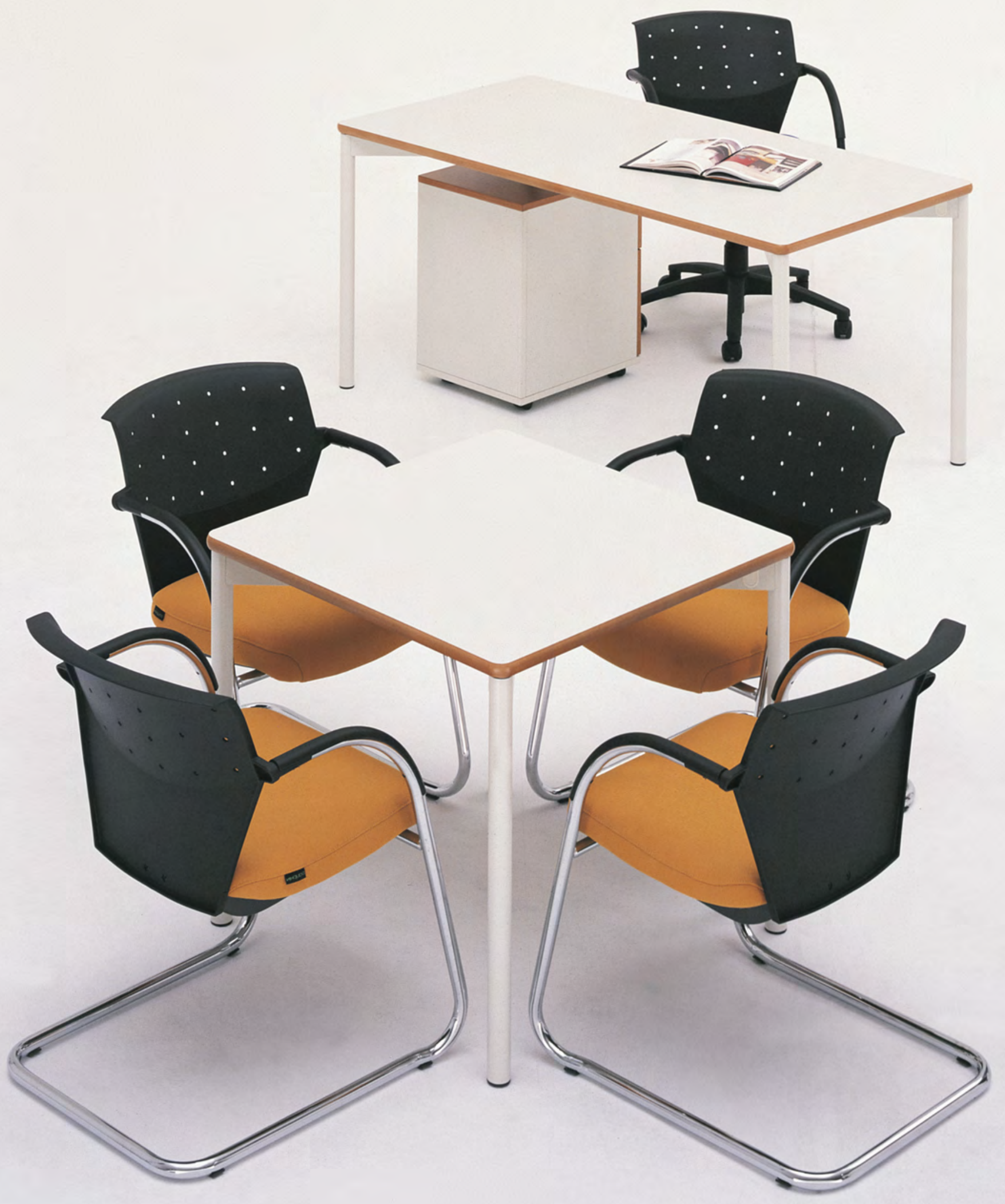


$900 \mid$ mesas de múltiplo uso

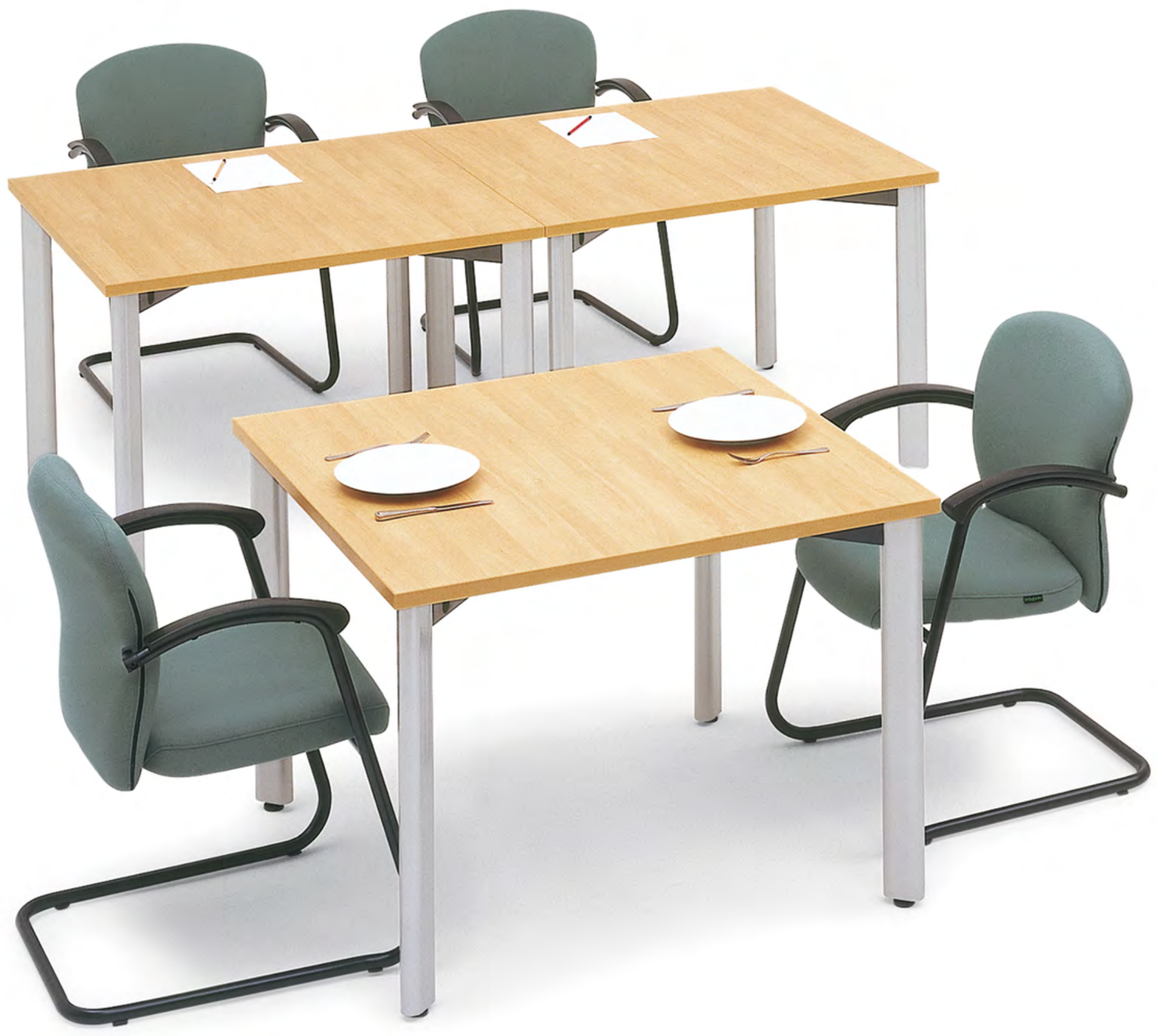

Mesas de múltiplo uso funcionam isoladamente ou

combinadas com os demais móveis da linha 900. 


\section{feiras}

Feiras são ocasiões muito especiais para as empresas de móveis, pois são eventos que demandam o trabalho de muitos de seus setores, desde o planejamento até a realização. Acontecem periodicamente, em geral de dois em dois anos e, para seu sucesso, os preparativos devem começar bem antes, obedecendo a cronogramas que, muitas vezes, coincidem com cronogramas dos projetos da própria empresa.

A presença em uma feira deve ser vista sob três aspectos. Em primeiro lugar, ela tem grande importância para o público interno, os funcionários de todos os níveis que desenvolvem, fabricam e comercializam os produtos. Nessas ocasiões todos têm a oportunidade de ver em conjunto as propostas concretas resultantes da dedicação de cada um. Se um projeto for bem executado, apresentado e, também, bem recebido pelo público, será um estímulo importante para todos, gerando segurança e satisfação de pertencer a uma organização competente.

Em segundo lugar, as feiras são boas oportunidades para comparar a produção da empresa com a dos concorrentes, posicionar-se em relação às suas qualidades, desenvolver uma autoanálise, entendendo isso como um processo permanente de aperfeiçoamento e aprendizagem. É sempre uma boa hora para se definir que medidas deverão ser adotadas depois, esclarecer e revisar os próprios conceitos e desenvolver ajustes na política da empresa. Esses procedimentos não devem ser isolados, pois uma decisão parcial, tomada apenas sob um mesmo prisma, provavelmente não daria resultados. Por conseguir reunir todos os setores da empresa, as feiras possibilitam elementos válidos para que as decisões tomadas sejam mais abertas e maduras.

Por fim, é importante nesses eventos a presença dos visitantes, em sua maioria pertencentes a um público especializado. Feiras não são lugares para fechar negócios, mas oportunidades para as empresas apresentarem o que têm de melhor, submeter suas ideias ao público, diferenciar-se da concorrência, deixando na memória de cada visitante a melhor informação possível sob todos os pontos de vista. Resultados comerciais de uma participação em feiras só poderão ser avaliados em médios e longos prazos.

Uma empresa criativa deve saber fazer na feira não apenas contatos que resultem em um retorno comercial. Deve também saber identificar e acrescentar informações importantes de várias naturezas e, com esses indicadores, posicionar-se melhor e com maior clareza no mercado, definindo suas estratégias. 

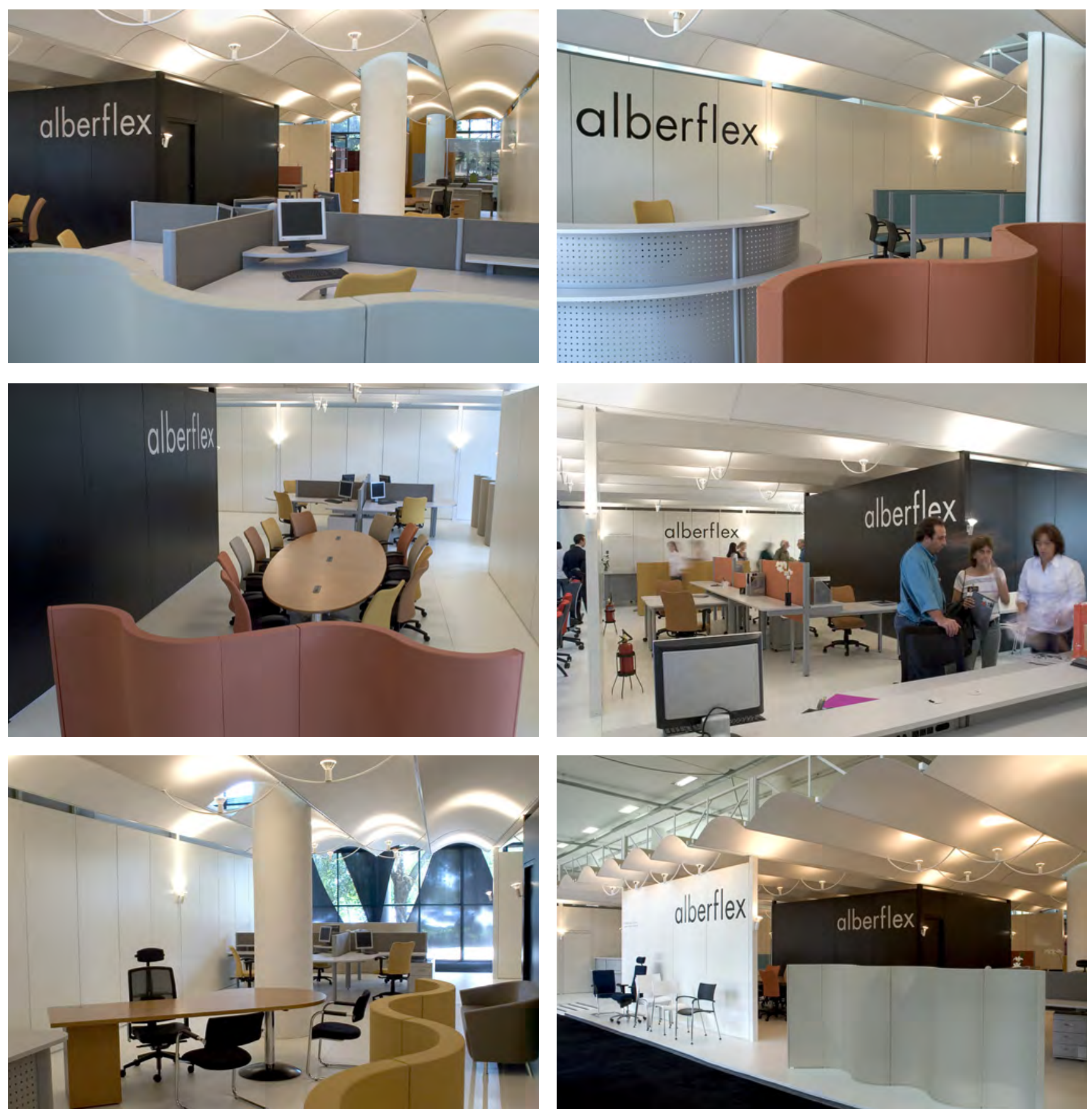
No trabalho desenvolvido por Bergmiller para a Alberflex é bastante evidente a presença de ideias que orientam seus projetos desde o início de sua trajetória pois, ainda nos tempos em que estudava em Ulm, como relata, sempre teve grande interesse por questões propostas por Charles Eames e George Nelson para a Herman Miller.

A Herman Miller era uma pequena empresa fundada em Michigan em 1905. George Nelson assim descreveu sua forma de trabalhar: "É uma pequena empresa em uma pequena cidade, dirigida pessoalmente por seus proprietários. O que a diferencia de outras empresas no mesmo setor são os seguintes princípios: 1. tudo o que faz é importante; 2 o design é um componente essencial da nossa atividade; 3 . o produto deve ser honesto; 4 . você decide o que vai ser produzido; 5 . existe um mercado para o bom design. 0 programa geral prevê o objetivo de se manter uma coleção permanente; isso significa que todo produto deverá manter-se atualizado com seu tempo e ser constantemente aprimorado". É uma adequada definição de uma política de design, paralela ou mesmo antecipatória àquela que seria desenvolvida por Hans Gugelot e Otl Aicher para a Braun, considerado o mais bem acabado exemplo do anseio por um design unitário.

Mas o conceito de unidade da Herman Miller era bem mais flexível, talvez devido às próprias influências de ideias tão diferentes e divergentes nascidas dentro da necessária convivência em uma sociedade mais eclética e variada como a americana. George Nelson foi o principal articulador dessas ideias. Foi inclusive um antecipador de problemas, narrando em um trecho de seus escritos como um homem do campo na Escandinávia lidava com sua alimentação, à custa de um pão integral, manteiga e uma faca. O pão, com forma redonda, adequava-se perfeitamente ao transporte em uma sacola; a manteiga já era guardada dentro do pão, por entre um corte triangular feito pela faca, cujo desenho da lâmina facilitava esse corte; depois de comer, as sobras não se transformavam em lixo, pois os pássaros delas se alimentariam. Podia parecer ingênuo para muitos daqueles entusiastas da industrialização democrática que veriam nas embalagens plásticas a possibilidade de distribuição de alimentos para todos, assim como para outros que, embora condenando a poluição, viam na narrativa de Goerge Nelson uma solução de tempos passados inaplicável na atualidade.

Mas não é texto para ser lido ao pé da letra. Nele estão contidas várias das ideias que nortearam algumas das diretrizes desses designers maiores que se destacaram na segunda metade do século XX: a ideia de um tempo que é contínuo, portanto nada é definitivo e tudo pode ser sempre repensado e retomado num sentido de melhor adequação e aperfeiçoamento; a ideia de que tudo pode ser preliminarmente pensado em sua forma mais simples e direta de solução; os princípios éticos de contenção, minimalismo e não desperdício; a ideia de que o design, desde a formatação do pão até a idealização de uma lâmina de faca apropriada a um corte triangular, deve ser uma atividade racional, como afirmaria depois Eames: 


\section{alberflex}
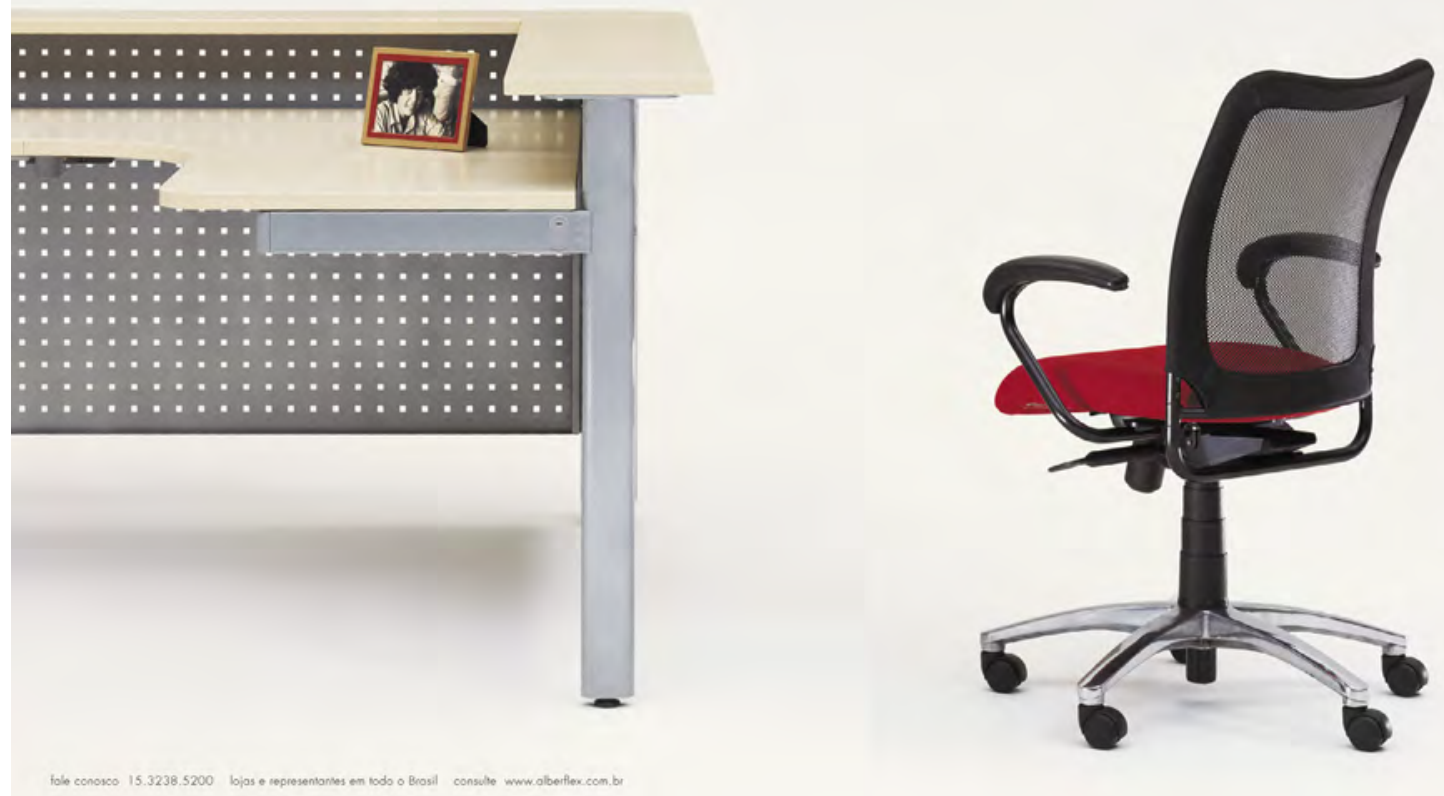

"O design não é uma forma genérica de expressão, mas um método de ação".

A atividade desenvolvida por Bergmiller na Alberflex não representa, portanto, uma repetição ou uma retomada, mas a continuidade de uma forma de pensamento que vê no design exatamente a característica afirmada por Eames. 